Wlademir José de Santis Junior

\title{
The Indonesian Throughflow and its association with the Atlantic Ocean circulation
}

Thesis submitted to Instituto Oceanográfico of Universidade de São Paulo, in partial fulfillment of the requirements for the degree of Doctor of Science in Oceanography, with emphasis in Physical Oceanography.

Advisor: Prof. Dr. Edmo J. D. Campos

Sao Paulo 


\section{The Indonesian Throughflow and its association with the Atlantic Ocean circulation}

\section{Wlademir José de Santis Junior}

Thesis submitted to Instituto Oceanográfico of Universidade de São Paulo, in partial fulfillment of the requirements for the degree of Doctor of Science in Oceanography, with emphasis in Physical Oceanography.

Evaluated in by

$\operatorname{Prof}(a) . \operatorname{Dr}(a)$.

Grade

$\operatorname{Prof}(a) . \operatorname{Dr}(a)$.

Grade

$\operatorname{Prof}(\mathrm{a}) \cdot \operatorname{Dr}(\mathrm{a})$.

Grade

$\operatorname{Prof}(\mathrm{a}) \cdot \operatorname{Dr}(\mathrm{a})$.

Grade

$\operatorname{Prof}(\mathrm{a}) \cdot \operatorname{Dr}(\mathrm{a})$.

Grade 
"Tudo foi calculado, exceto como viver."

Jean Paul Sartre

"Quando a educação não é libertadora, o so-

nho do oprimido é ser o opressor."

Paulo Freire

Ao meu filho dedico este trabalho, com o qual dividiu seu pai por anos. 


\section{Summary}

Summary .......................................

List of figures . . . . . . . . . . . . . . . . . . . . . . . . . iv

List of abbreviations . . . . . . . . . . . . . . . . . . . vii

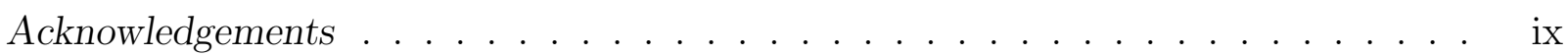

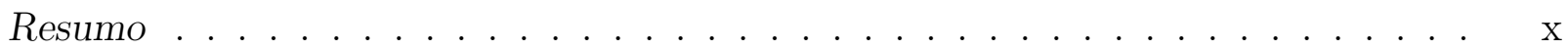

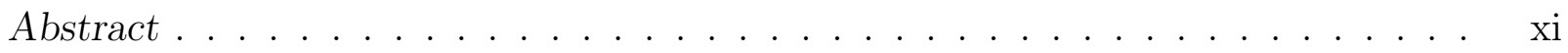

1. Introduction ........................ 1

1.1 The Indonesian Throughflow . . . . . . . . . . . . . . . . 1

1.1.1 What Drives the Throughflow? .............. 4

1.1.2 The Indonesian Throughflow in the Past Climate . . . . . . . . . 5 5

1.2 The Agulhas Leakage . . . . . . . . . . . . . . . . . . . . . . . . 7

1.2.1 The Agulhas Leakage in the Past Climate . . . . . . . . . . 8

1.3 The Meridional Heat Transport . . . . . . . . . . . . . . . . . . . . . . 9 9

1.3.1 The Meridional Heat Transport as a Constraint . . . . . . . . . . . 11

1.4 The Atlantic Meridional Overturning Circulation . . . . . . . . . . . . 12

1.5 The Idealized Topographies . . . . . . . . . . . . . . . . . . . . . . . [14]

1.6 Scientific Hypothesis . . . . . . . . . . . . . . . . . . . . 16

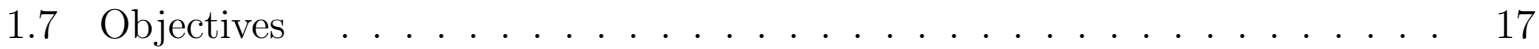




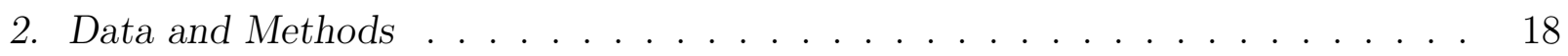

2.1 The Coupled Model . . . . . . . . . . . . . . . . . . . . . . . . . 18

2.1.1 The Atmospheric Model . . . . . . . . . . . . . . . . . . 18

2.1 .2 The Ocean Model . . . . . . . . . . . . . . . . . . . . . . 20 20

2.2 Experiments Designin . . . . . . . . . . . . . . . . . . . . 2 20

2.2.0.1 AquaPlanet . . . . . . . . . . . . . . . 20

2.2.0.2 Double Drake . . . . . . . . . . . . . . 20 20

2.2.0.3 Double Drake Extended . . . . . . . . . . . . . 21

2.2.0.4 Triple Drake First Version _ . . . . . . . . . . . 21

2.2 .0 .5 Triple Drake . . . . . . . . . . . . . 22

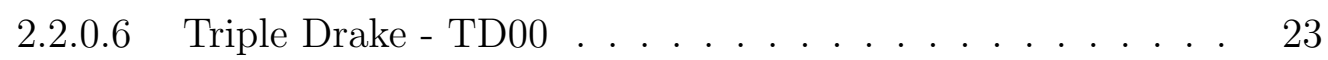

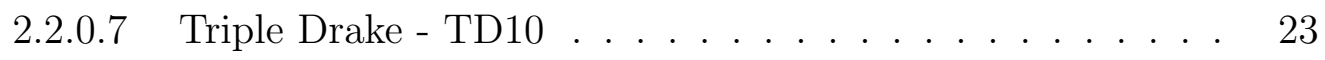

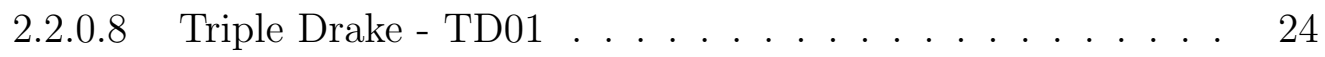

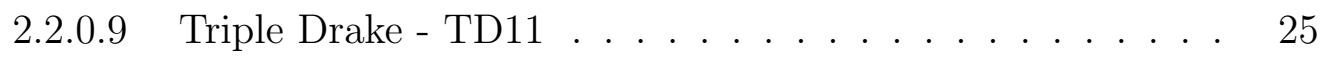

3. Results and discussion . . . . . . . . . . . . . . . 26 26

3.1 The Aquaplanet Experiment . . . . . . . . . . . . . . . . . . 26

3.1.1 The Aquaplanet's Mean State . . . . . . . . . . . . . 2 26

3.2 The Double Drake Experiment . . . . . . . . . . . . . . . . 28

3.2 .1 The DDrake's Mean State . . . . . . . . . . . . . . . . 28

3.2.1.1 Temperature (Figs. $3.2 a$ and $3.2 b) \ldots \ldots \ldots$

3.2.1.2 Surface Salinity and Freshwater Flux (Figs. $3.2 c$ and $3.2 d$ ) 28

3.2.1.3 Surface Wind and Currents (Figs. $3.2 e$ and $3.2 f$ ) $\ldots . \quad 28$

3.2.1.4 Global Overturning Circulation (Figs. $3.2 \mathrm{~g}$ and $3.2 h$ ) . . 30

3.2.1.5 Ocean Deep Convection . . . . . . . . . . . . . 30

3.2.1.6 Meridional Heat Transport (Fig. 3.6) . . . . . . . . . . . 33

3.2.2 Remarks on the DDrake Mean State . . . . . . . . . . . . . 34

3.2 .3 DDrake Variability . . . . . . . . . . . . . . . . . . . . 34

3.2.3.1 Salinity Anomalies and Freshwater Flux . . . . . . . 38

3.2.3.2 The Atmospheric Meridional Cells . . . . . . . . . . . 41

3.2.3.3 Meridional Heat Transport . . . . . . . . . . . . . 47

3.2.4 Remarks on DDrake's Variability . . . . . . . . . . . . . 48 
3.3 Intermediate Experiments . . . . . . . . . . . . . . . . 50

3.3.1 DDrake Extended . . . . . . . . . . . . . 50 50

3.3.2 Triple Drake First Version . . . . . . . . . . . . . . . 51

3.4 The Triple Drake Experiment . . . . . . . . . . . . . . . . 51

3.4.1 The TD00 Mean State . . . . . . . . . . . . . 53

3.4.2 The Agulhas Leakage effect . . . . . . . . . . . . 555

3.4.3 The Indonesian Throughflow . . . . . . . . . . . . . 5 59

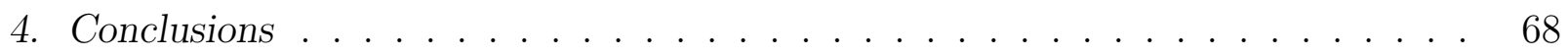

Bibliography .............................. 74 


\section{List of Figures}

1.1 The most relevant Gateways of the Indonesian Throughflow. . . . . . . . . 1

1.2 The Meridional Heat Transport from the NCEP reanalysis. . . . . . . . . . 10

1.3 The Meridional Heat Transport partition between the Atlantic, Indian and Pacific oceans. . . . . . . . . . . . . . . . . . . . 10

1.4 The Atlantic meridional overturning stream function from HYCOM. . . . . 13

1.5 Idealized topographies investigated in previous studies. . . . . . . . . 15

2.1 Topography of the Double Drake Extended experiment. . . . . . . . . . . . 21

2.2 Topography of the Triple Drake First Version. . . . . . . . . . . . . . . . . 22

2.3 Idealized topography for the TD00 experiment. . . . . . . . . . . . 23

2.4 Idealized topography for the TD10 experiment. . . . . . . . . . . . . . 24

2.5 Idealized topography for the TD01 experiment. . . . . . . . . . . . . 24

2.6 Idealized topography for the TD11 experiment. . . . . . . . . . . . . 25

3.1 The Eulerian atmospheric MOC, the residual oceanic MOC and the potential temperature for ocean and atmosphere in the Aquaplanet experiment.

3.2 The mean SST, surface air temperature, SSS, freshwater flux, currents, wind stress and the atmospheric and ocean MOC, for the DDrake experiment. .

3.3 Meridional Overturning stream function in the Atlantic-like and Pacific-like basins for the DDrake experiment. . . . . . . . . . . . . 30

3.4 The convection adjustment Index in the top $700 \mathrm{~m}$ for the DDrake experiment. 31

3.5 Comparison between the zonal salinity anomaly in the Atlantic between DDrake and observations. 
3.6 Comparison of the meridional heat transport on the Aquaplanet, DDrake and estimative from NCEP reanalysis. . . . . . . . . . . 33

3.7 Time series and the wavelet analysis of the filtered OHT. . . . . . . . 35

3.8 Comparison between the mean convective Index and the mean vertical currents at $700 \mathrm{~m} \ldots \ldots \ldots \ldots \ldots \ldots \ldots$

3.9 Comparison between the composite of the AMOC and the EOF 3 of the

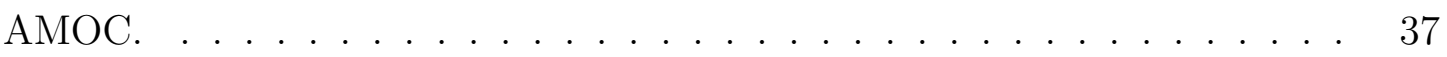

3.10 Linear correlation between the SSS and the deep convection over A2. . . 37

3.11 Hovmoller of the zonally averaged SSA over the Atlantic-like basin . . . . . 38

3.12 Mean SSS composites in the Atlantic-like basic. . . . . . . . . . . . . 39

3.13 The composite of freshwater flux zonally averaged over the Atlantic-like basin. 40,

3.14 The first EOF of the SSS and freshwater flux over the Atlantic-like basin. . 41

3.15 Comparison between the composite of the AtMOC and its EOF 2 . . . . 42

3.16 The spectrum of variability for the atmospheric MOC EOF 2. . . . . . 43

3.17 Composites of heat and salinity anomalies associated to the zonal Index-like

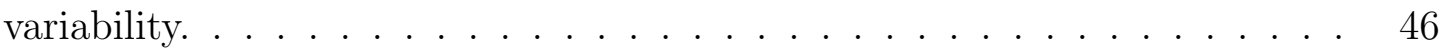

3.18 Correlation between the OHT Vs AMOC and AHT Vs ITCZ position. . . 47

3.19 Comparison between the zonal wind from NCEP and DDrake, indicating the latitudinal end of America, Africa and Australia. . . . . . . . . 52

3.20 Comparison between the meridional heat transport and its partition in TD00 and from NCEP reanalysis, as also the convective adjustment Index for this

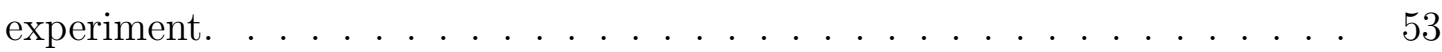

3.21 The SSA among the Triple Drake experiments. . . . . . . . . . 555

3.22 The anomalies in surface density among the Triple Drake experiments. . . 56

3.23 The anomalies in the meridional overturning in the Atlantic-like and Pacificlike among the Triple Drake experiments. . . . . . . . . . . . . 5 57

3.24 The zonally averaged salinity anomaly in the Atlantic-like and Pacific-like for TD10 minus TD00. . . . . . . . . . . . . . . . . . . 58

3.25 The anomalies in the temperature averaged in the upper $300 \mathrm{~m}$ among the Triple Drake experiments. . . . . . . . . . . . . . . . 59

3.26 The area averaged salinity over the northern Atlantic-like and Pacific-like for all the Triple Drake experiments. 
3.27 The freshwater flux anomalies due to the Throughflow. . . . . . . . . 62

3.28 The anomalies on the atmospheric MOC due to the Throughflow. . . . . . 63

3.29 Comparison between the OHT and AHT anomalies due to the Throughflow. 64

3.30 Anomalies in the zonal wind due to the Throughflow. . . . . . . . . . . 66 


\section{List of abbreviations}

$A A B W$-like Antartic-like Bottom Water.

AAIW-like Antartic-like Intermediate Water.

ACC Antarctic Circumpolar Current.

AHT Atmospheric Heat Transport.

AL Agulhas Leakage.

AMO Atlantic Multidecadal Oscillation.

AMOC Atlantic Meridional Overturning Circulation.

AtMOC atmospheric meridional overturning circulation.

DDex Double Drake Extended.

DDrake Double Drake.

ENSO El-Niño-Southern Oscillation.

EOF Empirical Orthogonal Function.

FWF Freshwater flux.

HYCOM Hybrid Coordinate Ocean Model.

INSTANT International Nusantara Stratification and Transport.

IT Indonesian Throughflow. 
ITCZ Intertropical Convergence Zone.

LGM Last Glacial Maximum.

MOC Meridional Overturning Circulation.

NADW North Atlantic Deep Water.

NADW-like North Atlantic-like Deep Water.

NCAR National Center for Atmospheric Research.

NCEP National Centers for Environmental Prediction.

OHT Ocean Heat Transport.

$P B L$ planetary boundary layer.

PMOC Pacific-like Meridional Overturning Circulation.

SACW-like South Atlantic-like Central Water.

$S D$ standard deviation.

Speedy Simplified Parameterization, Primitive Equation Dynamics.

SSA sea surface salinity anomaly.

SSS sea surface salinity.

SST sea surface temperature.

TDv0 Triple Drake First Version.

THC Thermohaline Circulation.

THT total meridional heat transport.

WOA09 World Ocean Atlas 2009 dataset. 


\section{Acknowledgements}

Ao tentar listar meus agradecimentos, parece-me que a ordem é importante. Deixo claro que não o é.

Dito isso, agradeço aos meus pais. A eles devo tudo. Às minhas irmãs, pela paz de uma

família tranquila. À Marcela, pelo amor, paciência e incentivo. Agradeço sobremaneira ao meu filho, Eduardo, pelo apoio sincero de uma criança. Pela incrível capacidade de compreensão. Por tudo aquilo que me é impossível descrever em palavras.

Ao meu orientador Dr. Edmo J. D. Campos, que me aceitou como aluno e possibilitou esse sonho.

Agradeço aos amigos Luis David Aímola e Paola Castellanos, que atuaram ao longo desses anos como co-orientadores deste trabalho. Peço aqui também minhas desculpas por essa participação não ter sido devidamente oficializada.

À Claudia Omachi, pelas conversas e dicas ao longo desse processo.

Aos funcionários da secretaria, Ana Paula, Letícia, Daniel e Silvana. Obrigado pela pasciência e disponibilidade em me explicar incansavelmente os procedimentos do instituto.

Agradeço aos amigos Eder, Guilherme e Wevertou, posto que amigos são sempre fundamentais em tudo aquilo que fazemos.

Sem investimento em educação, não se prospera como indivíduo ou como nação. Portanto, como aluno e como pai, agradeço ao CNPq pelo apoio financeiro, sob o projeto $\mathrm{n}^{o}$ : $140821 / 2013-9$.

Ao Instituto Vale de Tecnologia, pelo suporte financeiro e técnico recebido durante dois anos desse trabalho.

À FAPESP, pelos projetos CALSA 2010/01943-8 e SAMOC 2011/50551-4, os quais disponibilizaram os recursos computacionais utilizados nesse trabalho. 


\section{Resumo}

Experimentos com um modelo acoplado oceano-continente-atmosfera-gelo marinho e topografias idealizadas foram empregados para investigar os impactos que contornos laterais nos oceanos desempenham no clima. Os experimentos consideram um planeta idealizado, coberto por um oceano de profundidade constante, onde barreiras com um ponto de grade de espessura foram gradualmente adicionadas. Esta série de experimentos permitiram investigar vários aspectos do sistema acoplado em termos de seu equilíbrio e variabilidade, finalizando com a análise dos efeitos devidos ao Fluxo da Indonésia. Ao invés de investigar os impactos que este fluxo tem sobre o clima atual, o que tem sido bastante explorado em experimentos numéricos nas últimas décadas, a investigação é feita num clima alternativo, que configura um possível cenário durante períodos glaciais. Foi encontrado que a mudança na origem das águas que compõem o Fluxo da Indonésia altera em vários aspectos seus impactos como são conhecidos no clima atual. Em suma, o Fluxo da Indonésia atua dentro de um mecanismo de gangorra inter-hemisférica na circulação termoalina no sentido de reestabelecer a fase anterior desse mecanismo tipo gangorra.

Palavras-chave: Fluxo da Indonésia, Experimentos Idealizados, Efeito Gangorra Inter-hemisférico, AMOC. 


\section{Abstract}

Experiments with a coupled atmosphere-ocean-sea ice model using idealized topographies were run to investigate aspects of the role that the lateral ocean constraints play in the climate. The experiments consider an idealized planet covered with a constant deep ocean, where one-grid-wide land barriers were gradually added. The series of experiments allowed the investigation of many aspects of the coupled system equilibrium and variability, ending with an evaluation of the effects of the Indonesian Throughflow. Rather than to investigate the throughflow's impacts in modern climate, which has been largely explored in numerical experiments in the past decades, the throughflow is investigated in an alternative climate, argued as a possible scenario during ice-age periods. It was found that the change in the hemispheric water source of the throughflow affects many aspects of its impact as it is known for modern climate. In summary, the throughflow acts within the inter-basin seesaw in the sense to restore the previous phase of the inter-basin seesaw.

Keywords: Indonesian Throughflow, Idealized Experiments, Inter-basin Seesaw Effect, AMOC 
Chapter 1

\section{Introduction}

\subsection{The Indonesian Throughflow}

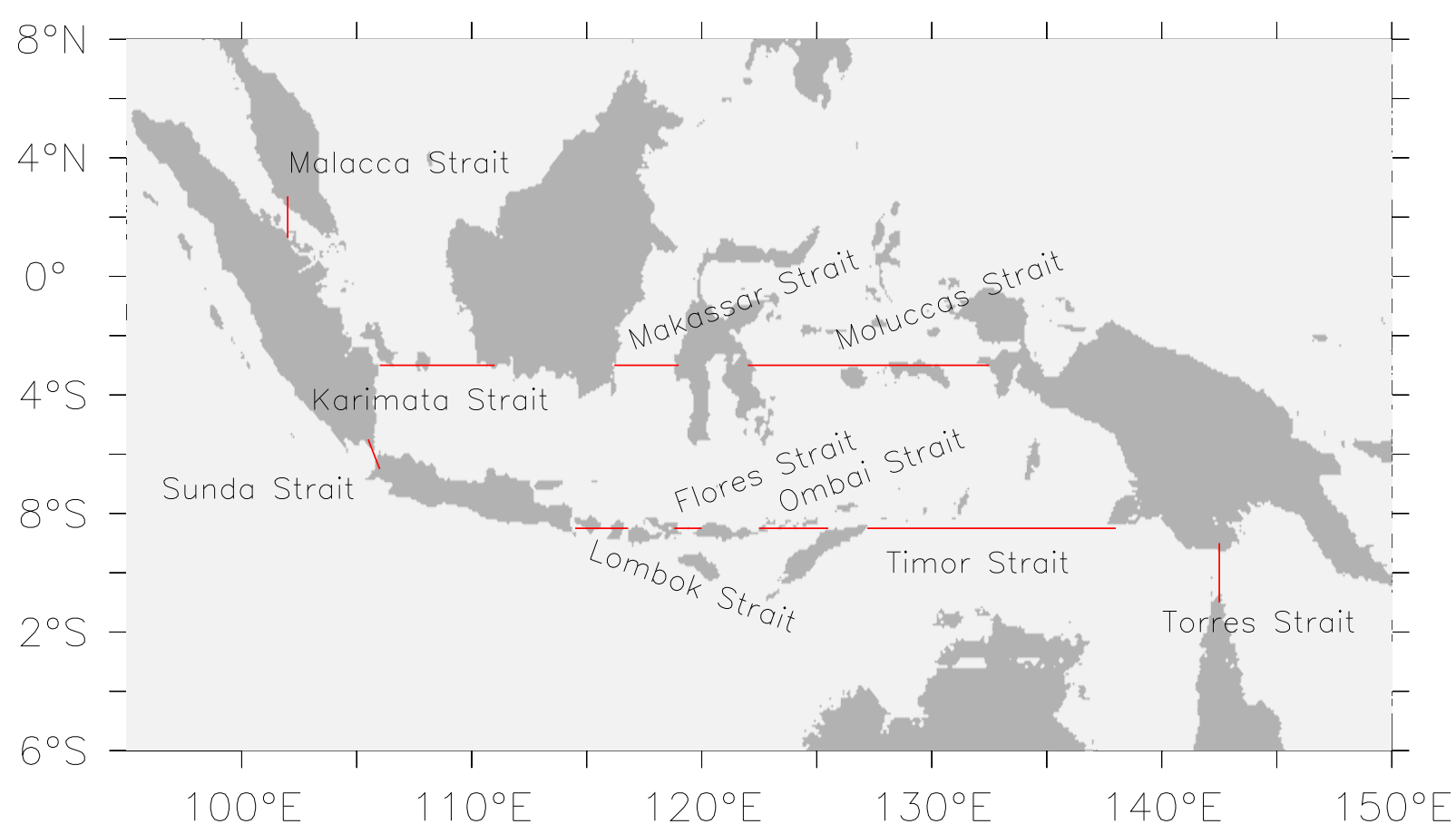

Figure 1.1: The most relevant Gateways of the Indonesian Throughflow.

The Indonesian Throughflow (IT) is the unique inter-ocean water exchange in low latitudes in the world, connecting the Pacific and Indian oceans by a complex set of channels (Fig. 1.1). It is the returning surface branch of the global Thermohaline Circulation (THC), that brings the warm and fresh Pacific water through the Indonesian Gateways into the Indian Ocean (Gordon, 1986). Through its role in the mass, heat and salt exchange between the Pacific and the Indian Ocean, the IT is believed to have a significant impact on the ocean circulation and climate. 
The IT affects the mass balance of the Pacific Ocean by exporting the North (70\%) and South (30\%) Pacific thermocline and intermediate waters into the Indian Ocean van Sebille et al., 2014), which would be otherwise returned into the western Pacific equatorial current system (Gordon, 1986; Gordon et al., 2003). The equatorial upwelling is further intensified and the sea surface salinity (SSS) drops in the Pacific on the presence of the IT (Hirst and Godfrey, 1993, 1994; Song et al., 2007). In the Indian Ocean, the IT water flows westward enhancing the South Equatorial Current. The main flow crosses the Indian Ocean, while the remaining part flows southward and south-eastward where it sinks near the West Australian coast. The downwelled flow further reverses into the undercurrent that returns back towards Madagascar, strengthening the Agulhas Current. Therefore, the IT impacts on both horizontal and vertical circulation in the Indian Ocean. The IT reaches the Atlantic within the Agulhas Leakage (AL), which integrates into the subtropical gyre (Le Bars et al., 2013) and the supergyre (Speich et al., 2007), while a minor part reaches the north Atlantic in a decadal time scale, feeding the Atlantic Meridional Overturning Circulation (AMOC).

The heat transported by the IT into the Indian Ocean makes a substantial loss for the equatorial Pacific Ocean heat budget (Godfrey et al., 1993). The main thermal response to the IT is the warming of the upper Indian Ocean and cooling of the upper Pacific Ocean. The largest temperature differences due to a blocked IT are found in the main thermocline, while the sea surface temperature (SST) signal is small in both oceans except for the regions with strong upwelling or convective mixing such as the Agulhas Current and the downwelling region off western Australia (Hirst and Godfrey, 1993, Godfrey, 1996; Schneider and Barnett, 1997; Schneider, 1998; Song et al., 2007; Wajsowicz and Schneider, 2001). The enhanced IT heat transport leads to strengthening of the Leeuwin Current system by increasing the steric height off northwestern Australian coast (Godfrey, 1996).

The IT plays an important role in the tropical climate by influencing the position and extent of the west Pacific warm pool. Coupled ocean-atmosphere general circulation models show that the IT shifts further west the warm pool and the centers of deep convection in the atmosphere (Schneider and Barnett, 1997; Schneider, 1998; Song et al., 2007). As a result, the atmospheric pressure in the entire tropics and the related surface wind stress is changed, triggering teleconnections patterns into higher latitudes. Blocking of the IT results in an El-Niño-like signal in the Pacific and a pattern similar to the Indian Dipole 
Mode over the Indian Ocean (Wajsowicz and Schneider, 2001). Changes on frequency and amplitude of warm phase of El-Niño-Southern Oscillation (ENSO) are also associated to the IT, accounting for part of its impacts on the time-mean averages (Song et al., 2007). In the Indian Ocean, blocking of the IT leads to colder SSTs in the eastern and warmer temperatures in the western basin. The resulting wind signal is an increase in southeast trades and a northward shift in rainfall from Indonesia, as a small increase of rainfall over East Africa. The response of the Pacific Ocean is an enhanced warming in the eastern equatorial Pacific associated with increased anomalies in wind stress and in precipitation along the equator.

Estimating the IT transport magnitude and variability has been a challenging task due to the high detailed topography of the Indonesian Gateways. Estimates of the IT transport usually focus on one or a few specific gateways, ranging from almost 0 to 20 $\mathrm{Sv}\left(1 \mathrm{~Sv} \equiv 10^{6} \mathrm{~m}^{3} \mathrm{~s}^{-1}\right)$ depending on the method and data used in calculation (Fieux et al. 1994; Gordon et al., 1999; Hautala et al., 2001; Meyers et al., 1995; Molcard et al., 2001; Murray and Arief, 1988; Susanto and Gordon, 2005; Wyrtki, 1961). Although there are observational programs to measure the IT transport (eg.: International Nusantara Stratification and Transport (INSTANT); see Sprintall et al., 2004), long-term simultaneous measurements within both inflow and outflow passages to unambiguously determine the mean magnitude of the IT are still lacking.

The IT transport shows high variability on both inter and intra-annual time-scales, whereby individual getaway's transport may be out of phase. The transport through Makassar Strait peaks in boreal summer during the southeastern monsoon with its maximum in June, and is lowest in boreal winter during the northwestern monsoon with its maximum in December (Gordon et al., 1999; van Sebille et al., 2014). Out-of-phase seasonal cycle is observed on Karimata transport, which peaks in boreal winter and reverses flows in boreal summer (Fang et al., 2010; van Sebille et al., 2014; Susanto et al., 2013).

The ENSO in the Pacific Ocean and the Indian Ocean variability are suggested to play a role on the IT interannual variability: typically the transport is stronger during La Niña years and weaker during El Niño years, specially on Makassar Strait (Du and Qu, 2010; England and Huang, 2005; Meyers, 1996; Potemra and Schneider, 2007; Yuan et al., 2011). The hemispheric water source of the IT also appears to be dependent of the ENSO phase, but it is different on each passage. On Makassar Strait there is an increased South Pacific 
waters during La Niña events, while the souther water increases during El Niño on the Moluccas Strait van Sebille et al., 2014, Valsala et al., 2011). However, the understand of the individual response of each passage to ENSO still lacks observations and detailed numerical experiments.

\subsubsection{What Drives the Throughflow?}

The first attempt to explain the IT transport has suggested it was driven by a pressure head between the Pacific and Indian Ocean (Wyrtki, 1961, 1987), based on hydrographic observations, sea level records, ship drifts and climatological wind patterns. The assumption was that the IT magnitude can be correlated with the sea-level difference between Davao (Philippines, West Pacific) and Darwin (Australia, East Indian Ocean). However, the Davao record was found to be a poor indicator of sea-level variability in the western Pacific.

Godfrey (1989) formulated an island rule based on a Sverdrup model to estimate the mean IT magnitude. The island rule is derived by integrating the depth-averaged, linear, horizontal momentum equations for the stratified ocean, subjected to a wind forcing. In the simplest formulation, the island rule states that the long-term (inter-annual or longer timescales) depth-integrated transport of the IT can be obtained by the wind stress line integral across the Pacific and around Australia and New Guinea. The prevailing winds cause an increase in sea level on the western side of the oceans and a lowering on the eastern side. Additional components to the island rule include topographic and frictional effects as well as the pressure difference between the northern and southern entrances to the Indonesian Seas that balances the alongshore wind stress. Godfrey's island rule gives an estimate of the net mean depth-integrated transport of $16 \pm 4 \mathrm{~Sv}$ using annual mean wind stress. Considering the simplicity of such method, this transport is in very good agreement with the net outflow of $15 \mathrm{~Sv}$ found during the 3 year INSTANT observational program (Sprintall et al., 2009), as also to the Lagrangian estimative of $14.3 \mathrm{~Sv}$ from van Sebille et al. (2014). These differences, however, and earlier estimative ranging from 10 to $12 \mathrm{~Sv}$ (Gordon et al., 1999; Meyers et al., 1995; Murray and Arief, 1988; Wajsowicz et al., 2003), suggest that frictional and topographic effects might play a significant role in reducing the net Pacific to Indian Ocean transport on the island rule. Wajsowicz $1993 \mathrm{a}, \mathrm{b}$, 1994) further modified Godfrey's island rule to account for the complex geometry of the 
Indonesian Gateways by including the bottom topography, frictional effects and multiple straits, reducing the net transport.

Although the island rule and ocean general circulation model experiments confirms the controlling effect of that the wind stress over Pacific exerts on the depth-integrated throughflow, topography effects and density driven flows are still a source of disagreements between the analytical and simulated results (Wajsowicz and Schneider, 2001).

A different explanation was presented by Andersson and Stigebrandt (2005) where only density gradient between the Pacific and the Indian Ocean is considered to drive the Throughflow. The Indonesian Seas are thought to be filled by low-saline water of North Pacific, creating a downstream buoyant pool that stretches horizontally over a large part of the North Australian Basin. The IT is then controlled by the baroclinic transport capacity of the downstream buoyancy pool to the adjacent Indian Ocean, given an IT of about 10 Sv. However, these estimates crucially depend on the width and depth of the pool as well as on the reference temperature and salinity used in calculation.

The present theory of the IT forcing still leaves unanswered questions, and new information regarding the throughflow dynamics is required in order to improve its prediction on transport magnitude and variability.

\subsubsection{The Indonesian Throughflow in the Past Climate}

The most straightforward impact of glacial climate conditions on the Indonesian Gateways is the sea level lowering associated with the global ice-sheet growth. Reconstruction on the sea level change on the Last Glacial Maximum (LGM), around 23-19 ky ago, suggest a lowering between 120 and 136 m of ice volume equivalent (Hanebuth et al., 2000; Lambeck et al., 2002, Peltier, 2002; Yokoyama et al., 2000). Land-sea distribution in the Indonesian Gateways changed significantly with the lowering of the sea level. Java Sea was exposed and the communication with the South China Sea was blocked. The North Australian Shelf was dry and the overall exposed land area almost doubled (De Deckker et al., 2003). The sea level lowering closed most of the small and narrow Indonesian passages and significantly changed the aperture of the main straits by reducing the width of the channels and depth of the sills.

Considering glacial to interglacial changes in the paleoproductivity and nutrient utilization in the Timor Strait, Müller and Opdyke (2000) suggested that the IT was reduced in 
strength during the glacial periods. The observed glacial increase in productivity appears to be related to the weaker IT transport, as spreading of the IT low salinity surface waters inhibits vertical mixing and reduces productivity in Timor Strait. Weaker Throughflow and the sea level lowering during the LGM would, therefore, enhance the possibility of upwelling and higher productivity.

Further indications for the reduction in the IT strength has been deduced from the clay mineral distribution in surface sediments between Indonesia and northwestern Australia (Gingele et al., 2001b a). The distribution of clay minerals is closely related to the surface and subsurface ocean currents. Evidence from Timor Passage shows a reduction in the current speed as indicated by the accumulation of finer material during glacial periods. Decrease of kaolinite and chlorite originating from the Java Sea during the LGM could be related to overall reduced advection by the IT. However, clay mineral distribution is not only related to changes in the current system, thus assumptions on the changes in the land-sea distribution, hydrological cycle and related river runoff are, therefore, necessary for the interpretation of the clay mineral patterns and are prerequisite to determine the changes in the Throughflow strength.

The SSS reconstruction in the IT region is ambiguous. There are few observational sites where both $\mathrm{Mg} / \mathrm{Ca}$ and oxygen isotope records are used to estimate salinity changes. Increases in salinity were confirmed by both $\delta^{18} \mathrm{O}$ and $\mathrm{Mg} / \mathrm{Ca}$ composition of planktonic foraminifera measurements in the Mindanao Sea (Stott et al., 2002) and Makassar Strait (Visser et al., 2003). This is, however, in contrast with the salinity anomalies derived from the Sulu Sea (Dannenmann et al., 2003; Oppo et al., 2003; Rosenthal et al., 2003) and Ontong Java Plateau (Lea et al., 2000), where the data indicate fresher conditions at the LGM.

De Deckker et al. (2003) considered that the increase in land area would favor a drop in precipitation and related increase in salinity throughout the region. However, vegetation reconstructions based on the organic carbon records from the sediment core recovered from Makassar Strait (Visser et al., 2003) suggest no significant change in vegetation in the region indicating similar hydrological conditions, indicating the SSS increase is not driven locally. 


\subsection{The Agulhas Leakage}

The gap between the southernmost tip of Africa and the latitude of zero wind stress curl, over the maximum westerlies, allows a flow of relatively warm and salty water from the Agulhas Current of the Indian Ocean into the Atlantic Ocean, the so-called Agulhas Leakage (Gordon, 1986).

The AL depends on the interaction of the far field forcing (e.g.: the wind stress strength and pattern on the Indian Ocean, the IT and the Mozambique eddies) and its own local dynamics. In modeling studies, the local dynamics of the AL presents different regimes. By investigating several idealized setups of the Agulhas region, Dijkstra and de Ruijter (2001) showed the existence of two regimes controlling the retroflection, depending on the balance of the momentum equation: when the Agulhas Current is weak and the viscosity is strong enough (greater Munk boundary layer width), the viscous terms dominates the retroflection (viscous choking). When the viscosity is reduced and(or) the Agulhas Current is increased, the inertial effects becomes dominant. A third and turbulent regime is described by Le Bars et al. (2012), which is observed at large wind stress amplitude. On this regime, the leakage reaches a plateau due to an increased mesoscale activity on the region. Thus, strength and position of the wind field over the Indian Ocean directly impacts on the AL, as it controls both inertia and the latitude of maximum westerlies.

Estimates of AL are highly uncertain, ranging between 2 and $15 \mathrm{~Sv}$ (Gordon et al., 1992). Most of the AL occurs in a form of rings, eddies and filaments, formed on the Agulhas Retroflection region. Schonten et al. (2000) observed a total of 21 rings on the TOPEX/Poseidon satellite altimetry between 1993 and 1996. Usually, half the decay of the long-lived rings takes place in the first 5 months after shedding, while about one third of the observed rings formed on the Cape Basin do not leave the region. In average, a ring takes about 2.5 to 3 years to cross the Atlantic. The estimates of the inter ocean volume transport by Agulhas rings range between 0.5 and $1.5 \mathrm{~Sv}$ per ring (see Gordon et al., 1992), while 5 to 6 rings per year is observed, leading to a ring-transport ranging between 2.5 and $9 \mathrm{~Sv}$.

The linkage between the AL to AMOC and global climate have been explored in several ocean and coupled climate models (Biastoch et al., 2008; Haarsma et al., 2011; Weijer et al., 2001, 2002). The variability of the AL can impact on the AMOC through buoyancy 
forcing (Weijer et al., 2001, 2002), affecting the Atlantic meridional pressure gradient and the preconditions to the northern Atlantic deep convection. Initially, the AL anomalies in salt and heat are largely density compensated, but the progressive dumping of heat loss increases density, as salinity is left behind. Through buoyancy forcing the leakage impacts on the overturning strength about 15-30 yr later, the advective time scale for the salt anomaly reach the North Atlantic (Biastoch et al., 2008; Haarsma et al., 2011).

The Agulhas rings entering the Atlantic triggers planetary waves that affects the AMOC (Biastoch et al., 2008; Cunningham et al., 2007; van Sebille and van Leeuwen, 2007). These perturbations contributes to the AMOC variability in short-term until decadal time scales, perhaps due to the Indian Ocean Dipole modes and the ENSO modulation of the Agulhas rings shedding (de Ruijter et al., 2004; Schouten et al., 2002).

\subsubsection{The Agulhas Leakage in the Past Climate}

The abundance of planktonic foraminiferal species on paleoceanographic records in the Agulhas ring corridor (Agulhas fauna) is used as a proxy for the leakage strength in the last 570 kyr (Peeters et al., 2004; Rau et al., 2006). Additionally, the ratio of subtropical and subpolar planktonic species on sites close to the modern subtropical front can be used to reconstruct the latitudinal position of the subtropical gyre and the subtropical front itself. The overall results show the AL transport to positively respond to a poleward migration of the westerlies maximum. During the glaciation terminations the AL peaks, while there is still substantial ice volume. It is also suggested that the leakage may have had a role in triggering the resumption of the AMOC. The changes in the leakage are accompanied by the meridional shift of the subtropical front by several degrees and changes in the deepocean ventilation, suggesting the AMOC strengthens during glacial-interglacial transitions Anderson et al., 2009; Lisiecki et al., 2008). Furthermore, severe glacial conditions are associated with northward migration of the subtropical front by about $7^{\circ}$ of latitude, when the Agulhas fauna suggests that the leakage was weak and possibly ceased Bard and Rickaby, 2009). 


\subsection{The Meridional Heat Transport}

The meridional heat transport is a fundamental aspect of the climate system, showing the efficiency of how the incoming energy over the tropics is redistributed poleward, thus determining how extreme the climate over the poles are compared to the tropics. It integrates all processes that transport heat meridionally, although it is usually thought only as the contribution from the ocean and atmospheric circulation, neglecting other process over land.

One of the most elucidating study regarding the meridional heat transport and its partition is presented by Trenberth and Caron (2001), results of which are summarized in Fig. 1.2. The total meridional heat transport (THT), from now considered as the sum of the ocean and atmospheric contribution, was estimated by the authors through satellite measurements of the top-of-the-atmosphere radiation, while the Atmospheric Heat Transport (AHT) is directly calculated with atmospheric reanalysis data (only the reanalysis from the National Centers for Environmental Prediction (NCEP)-National Center for Atmospheric Research (NCAR), Kalnay et al. (1996), referred to as NCEP, is shown on Fig. 1.2). By combining the THT and the AHT the surface fluxes can be determined and the Ocean Heat Transport (OHT) is calculated within physical constraints, such as the long-term changes in heat storage and the transports at the northern and southern limits of the domain. 


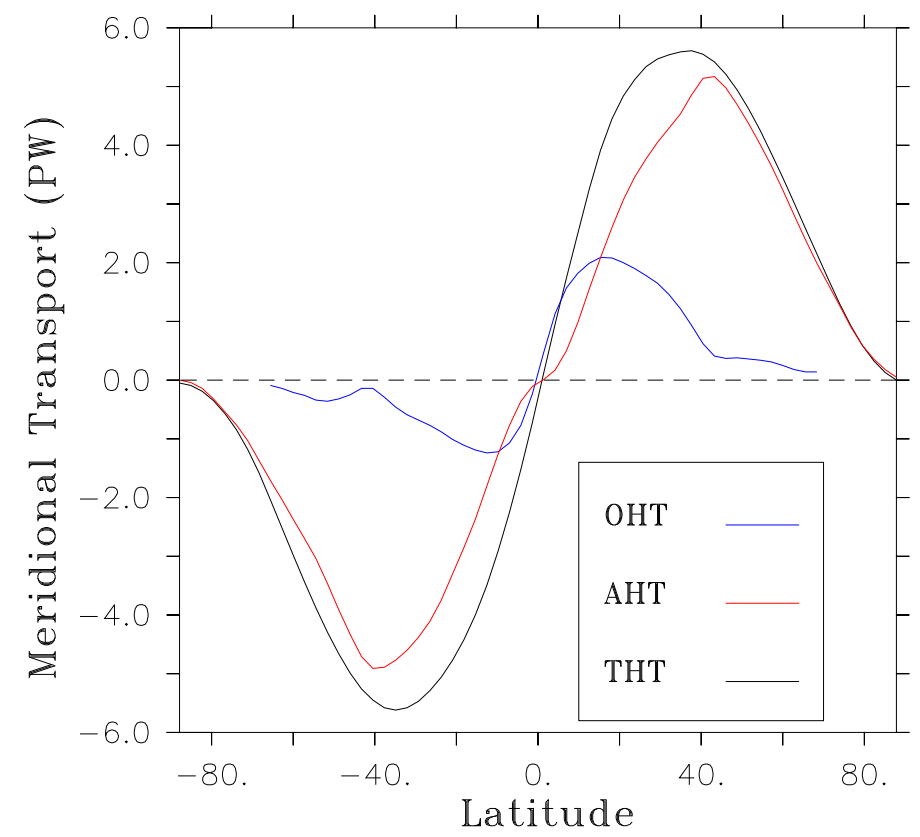

Figure 1.2: The required total heat transport from the top of atmosphere radiation (black line), the National Center of Environmental Prediction derived atmospheric heat transport (red line) and the ocean heat transport (blue line) adjusted to incorporate processes as the Bering Strait heat flux and the systematic changes on the heat storage in the ocean. Units in PW $\left(1 \mathrm{PW}=10^{15} \mathrm{~W}\right)$. See Trenberth and Caron (2001) for further details.

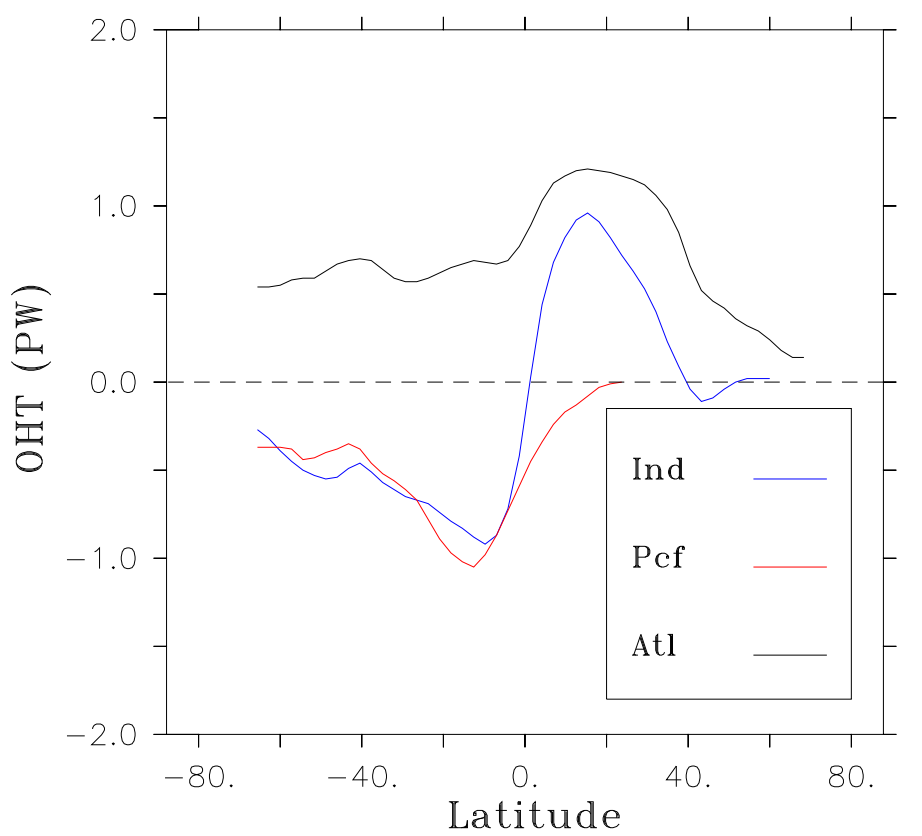

Figure 1.3: The individual contribution from the Atlantic, Indian and Pacific basin to the OHT. Units in PW. See Trenberth and Caron (2001) for further details.

The OHT is greater than the AHT only in tropical regions. In mid-high latitudes the AHT dominates the meridional heat transports, peaking around $40^{\circ}$ of latitude due to the intense eddy activity. 
The OHT can be partitioned between the relative contribution from the Atlantic, Indian and Pacific basin independently (Fig. 1.3p. Despite the meridionally symmetry in the total OHT (Fig. 1.2), each basin has a distinct contribution to the OHT. The most stark difference is the predominance of positive transport in the Atlantic basin over all latitudes, while in the Pacific the heat transport is mostly poleward in both hemispheres and in the Indian ocean it is mostly southward. The meridional heat transport in each basin directly reflects their thermohaline circulation. The positive transport in the Atlantic reflects the presence of an strong meridional cell, described on the next section, which transport warm thermocline waters northward and relative cold deep waters southward.

\subsubsection{The Meridional Heat Transport as a Constraint}

On Stone (1978) it is stated that when the planet is on thermodynamic equilibrium, the magnitude of the THT is determined primarily by the solar constant, the size of the earth, the tilt of the earth's axis and the hemispheric mean albedo. It means the THT would be insensitive to the processes responsible for the transport itself, or more specifically, independent of the partition between the ocean and atmospheric heat transports. Considering there is no change in the hemispheric mean albedo, the idea in Stone (1978) is a strong constraint to the equilibrium of the climate that ocean and the atmospheric circulations has to obey. The OHT and AHT could assume any configuration, but their sum would be prescribed by external parameters. Of course, however, the hemispheric mean albedo can in turn be changed depending on the OHT or the AHT arrangement, affecting the THT itself.

Considerations regarding the Stone's idea and the ensuing constraint to the ocean and atmospheric circulation can be identified in investigations of more specific details of the climate dynamics. Marshall et al. (2014) have shown that the mean AHT across the equator is mostly achieved by the transport of moist static energy in the upper circulation of the Hadley cell, while the mean OHT across the equator is mostly achieved by the Meridional Overturning Circulation (MOC). The authors argue that the north-of-equator mean position of the Intertropical Convergence Zone (ITCZ) is a consequence of the energy balance between the hemispheres, in the following way: The interhemispheric AMOC leads to an $\mathrm{OHT}$ of about $0.4 \mathrm{PW}$ across the equator, while there is a deficit of $0.2 \mathrm{PW}$ on the north hemisphere due to the top-of-atmosphere energy balance. It lefts $0.2 \mathrm{PW}$ to be 
transported by the atmosphere from the north to the south hemisphere. The authors have shown the moist static energy transport is more intense on the upper branch of the Hadley cell, hence by setting the ITCZ position right north of the equator, the ensuing moist static energy transport across the equator is negative, closing the energy balance with an AHT of about $-0.2 \mathrm{PW}$.

The correlation between the ITCZ and AHT as a response from imposed OHT in extratropics is investigated in Bischoff and Schneider (2015). A simplified equation to determine the ITCZ location from the AHT is derived and expanded in a Taylor series. It is found that for some values of the OHT on the extra tropics, their coupled model can be explained by the linear part of the equation as the ITCZ responds linearly to the imposed OHT, while for other OHT values it may incorporate other orders of the expansion, whereby the ITCZ response is no longer linear.

Overall, these results are within the Stones considerations and its ensuing energyimposed constraint. In other words, there are aspects of the mean ocean and atmospheric circulation that are coupled in order to close the energy budget, and a change in one aspect will lead to a response on the other.

\subsection{The Atlantic Meridional Overturning Circulation}

The so-called Atlantic Meridional Overturning Circulation is a large-scale ocean circulation of mass with extraordinary importance to the Eath's climate. It summarizes a complex system of currents that creates a net northward of warm water in the upper Atlantic, and a southward flow of colder water in the deep Atlantic (Wunsch, 2002). When this complex of currents are zonally integrated in the Atlantic basin, one can see the so called AMOC (Fig. 1.4). More precisely, the deep space AMOC is defined as the double integral of the meridional velocity at each latitude, or

$$
\psi_{M O C}(y, z)=\int_{-H}^{z} \int_{x_{w}(y, z)}^{x_{e}(y, z)} v(x, y, z) d x d z
$$

where $v$ is the meridional velocity at cartesian location $(x, y, z)$. Horizontal and vertical integration limits are respectively from the western $\left(x_{w}(y, z)\right)$ and eastern $\left(x_{e}(y, z)\right)$ boundaries, and from the botton $(-H)$ to the depth $z$. 


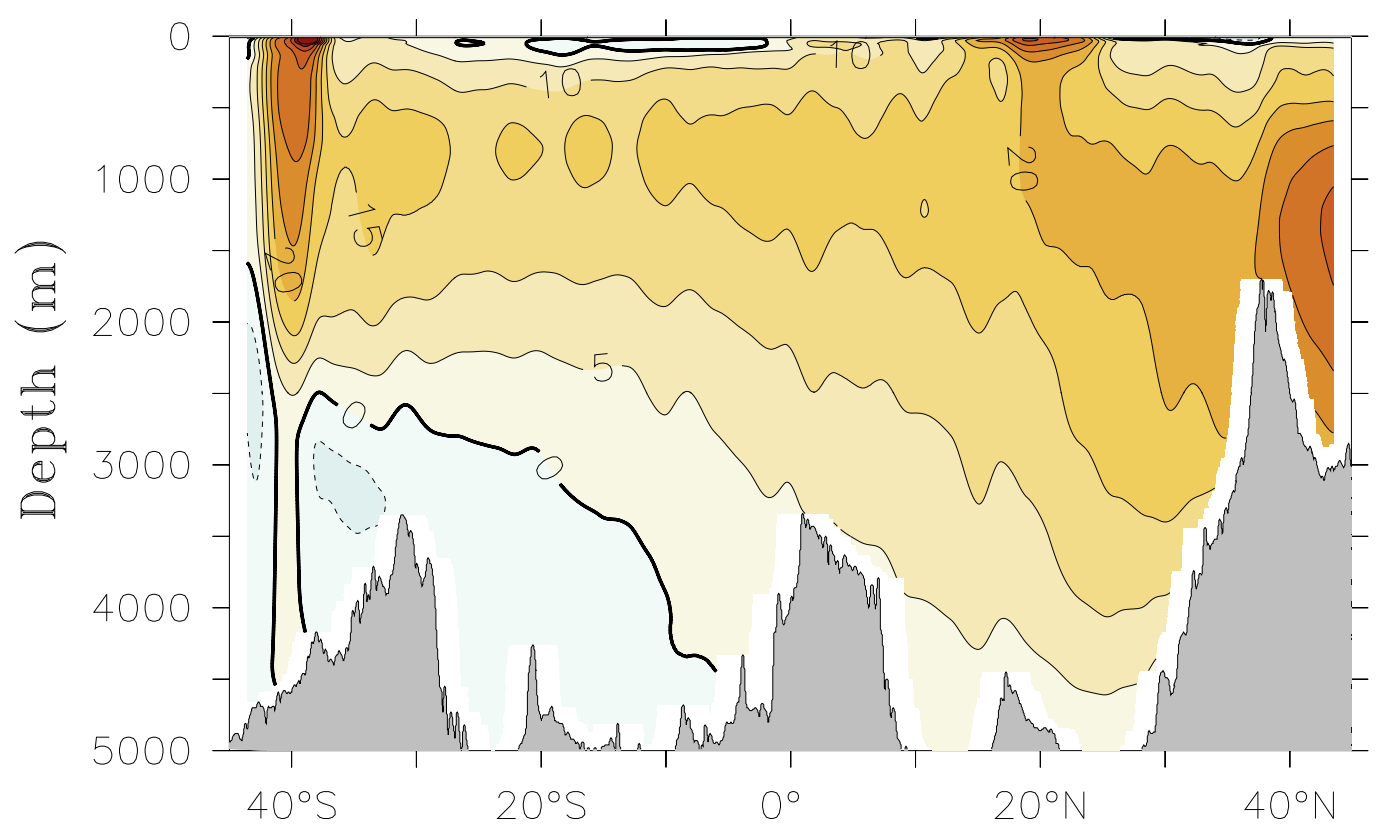

Figure 1.4: The Atlantic Meridional Overturning Stream Function from a global implementation of the HYCOM, using 32 sigma-2 levels, 1/12 degrees of horizontal resolution and forced by Reanalysis I from NCEP.

It is generally emphasized that as the upper ocean water flows northward, heat and freshwater is gradually lost to the atmosphere, increasing the water potential density until it sinks on high latitudes into the deep ocean and flows southward to complete an overturning cell. However, such description misleads the interpretation regarding what drives the AMOC. This discussion is still open.

There are arguments dating as far back as 1908 suggesting the AMOC is unsustainable as a convectively driven mass flux (Sandstrom, 1908). The ocean as a heat engine would not provide enough turbulence required to upwell the denser waters across the stable stratification gradient on the deep ocean (Paparella and Young, 2002). In the absence of the turbulent mixing, the deep ocean would became homogeneous and the abyssal currents would cease, differently from what is known from observations (Schmitz, 1987). Thus, the energy required for the eddy turbulent mixing should come from a mechanical forcing, and the main two candidates sources of this work would be tidal stirring and the wind field (Munk and Wunsch, 1998; Paparella and Young, 2002).

However, more recent results recover the importance of the surface buoyancy forcing for the AMOC energy budget. Hughes et al. (2009) demonstrate that, in a steady state, the irreversible mixing dissipates the available potential energy at the same rate at which it is generated, and that the surface buoyancy fluxes contribute to generate available po- 
tential energy in the same order of mechanical forcing. Thus, the rate at which energy is transferred within the system is of first order importance, as much as the surface buoyancy forcing.

The AMOC is thus best though as a mechanically driven fluid, which efficiency is dictated by the background stratification and surface buoyancy fluxes. Moreover, the AMOC transports vast quantities of heat, freshwater, dissolved gases etc, giving to it a great climate relevance (Wunsch, 2002).

The discussion regarding the past climate and the predictions to the future climate is often framed on the context of the AMOC variability, as it is thought as the major source of multidecadal climate variations (Delworth and Mann, 2000, Knight et al., 2005; Zhang, 2008). Its weakening or collapse has been associated to glacial periods and its strengthening to the recovering from these cold periods (Beal et al., 2011; Sijp and England, 2009). Regarding future scenarios of increasing greenhouse gases the AMOC is expected a gradually slowdown by $25( \pm 25) \%$ until 2100 (Schmittner et al., 2005$)$.

The AMOC has being found to substantially contribute to changes in the northern Atlantic surface atmospheric temperature and on the sea ice coverage (Mahajan et al. 2011). It is also suggested to be in phase to the Atlantic Multidecadal Oscillation (AMO) (Zhang, 2007, 2008). The AMO, defined as the observed detrended multidecadal SST anomaly averaged over the entire North Atlantic, has been linked to many aspects of the global and regional climate, as the Atlantic hurricane activities (Goldenberg et al., 2001), Sahel drought (Folland et al., 1986), North American and western Europe summer climate (Sutton and Hodson, 2005) and Northeast Brazilian rainfall (Folland et al., 2001), which suggests the AMOC to be important to these issues as well.

\subsection{The Idealized Topographies}

The full understanding of earth's climate is a great challenge, specially due to its complex nonlinear nature with multiples levels of interaction among processes that couple atmosphere, ocean, land and the life forms in the environment. However, many aspects of such system can be assessed with simplified approaches. That is the case for studies that has been using coupled models with idealized topographies to explain the main characteristics of the climate. It is shown that some features of the dynamic equilibrium of the 
oceans and atmosphere can be reproduced by simple configurations of land barriers.

In a sequence of studies, simplified experiments have been explored to create a progressive understanding of the climate, starting with an Aquaplanet where is added narrow meridional land barriers (Fig. 1.5). It is shown that by moving from the Aquaplanet (Fig. 1.5a) to the Drake experiment (Fig. 1.5b), the meridional asymmetry allows the formation of an interhemispheric meridional overturning that sinks on the North Pole and upwells on the southern ocean, crossing the equator and leading to a northward OHT across the equator, similar to the observations (Enderton and Marshall, 2009).

The Double Drake (DDrake) (Fig. 1.5c) experiment is explored by Ferreira et al. (2010) to explain the deep-water formation being restricted to the small basin. It is shown that the small basin salinization is from a deficit of precipitation rather than from excess of evaporation, due to the width of the small basin relative to the zonal fetch of atmospheric precipitation. Since the land barriers are one-grid-point wide with no effect of topography on the atmosphere, it results that most of the water evaporated on the small basin precipitates on the large basin, giving to the DDrake a remarkable resemblance to the real world, with a Atlantic and Indo-Pacific-like circulation.

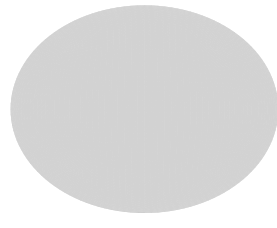

(a)

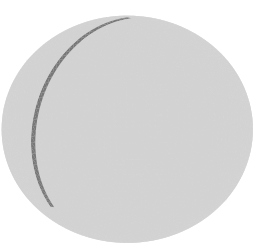

(b)

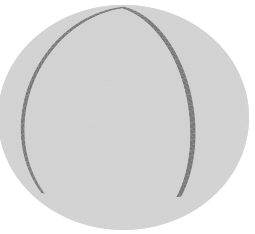

(c)

Figure 1.5: Idealized topographies for experiments AquaPlanet (a), Drake (b) and DDrake (c).

Using variations of the DDrake, Nilsson et al. (2013) explores the latitude termination of the land barriers and the basins widths to show that there is symmetric and asymmetric dynamical equilibriums when the barriers and basins are equal. Changes in the southward extent of the land barriers enhance or reduce the zonal asymmetries, depending on the wind-driven Sverdrup circulation that controls the inter-basin heat and salt exchange. Specifically, they show that when the short "African" continent is located near or equatorward of the zero wind line in the Southern Hemisphere, the deepwater formation is restricted to the Atlantic-like basin due primarily to a westward wind-routed inter-basin salt transport. The authors also suggest that both the continental extents and basin width 
asymmetries are strong enough to uniquely localize the deepwater formation to the Atlantic basin.

On Marshall et al. (2014) the idealized experiments approach is used to explain the north-of-equator mean position of the ITCZ. They show that the meridional heat transport balance between the ocean and atmosphere is the responsible for accommodating the ITCZ mean position. In Enderton and Marshall (2009), the THT of the Aquaplanet and other idealized experiments are compared to theoretical expectations from Stone (1978), finding that the THT is well reproduced by the Stone's idea when there is no ice-cap formation.

In summary, many features of the oceanic and atmospheric circulation has been well reproduced on such idealized experiments, while the overall complexity is reduced, attesting them to be well suited tools to explore relevant aspects of the climate. This tested ability guided the decision for using idealized experiments in the present investigation.

\subsection{Scientific Hypothesis}

As discussed in section 1.1, the IT is an important aspect of the modern climate. It was also pointed many evidences that the IT and the THC have experienced significant modifications on paleoclimatic time scales (Holbourn et al., 2011, Paul and Schäfer-Neth, 2003; $\mathrm{Xu}, 2014)$. Moreover, recent results have suggested a mechanism in which the THC would vary on millennial timescales (Sijp and England, 2009) through a seesaw behavior between the Atlantic and Pacific THC. This seesaw mechanism is shown to be triggered by freshwater forcing (Saenko et al. 2004) as also by the meridional shift of the Southern Hemisphere wind stress (Sijp and England, 2009), and reinforced by a feedback between salinity and the THC (Bryan, 1986a; Saenko et al., 2004).

The inter-basin seesaw mechanism is suggestive to the past climate as the equatorward shift of the Southern Hemisphere westerlies and the decreased AL are inferred on paleorecords and modeling studies (Bard and Rickaby, 2009; Berger and Wefer, 1996; Paul and Schäfer-Neth, 2003). Additionally, the influence of the AL on the variability and stability of the AMOC is well documented, whereas a stronger AL sustains a stronger and stable AMOC (Biastoch et al., 2008; Knorr and Lohmann, 2003; Weijer et al., 2001, 2002).

Evidences of the seesaw effect in the THC is also observed from paleorecords. Analyses of benthic stable isotope records suggest that the THC in the upper Northwest Pacific 
reverses when the North Atlantic Deep Water (NADW) formation was reduced, on glacialto-interglacial timescales (Duplessy et al., 1988; Keigwin, 1998). By analyzing sediment cores, Kiefer et al. (2001) inferred an antiphase link between the SST on North Pacific and North Atlantic, pointing to an oceanic inter-basin seesaw as an explanation. Negative correlation between the surface salinity on the western Pacific and temperatures on the North Atlantic were confirmed by both $\delta^{18} \mathrm{O}$ and $\mathrm{Mg} / \mathrm{Ca}$ composition of planktonic foraminifera measurements (Stott et al., 2002), what is also coherent to the inter-basin seesaw. Saenko et al. (2004) has reported a decrease in the IT transport when the inter-basin seesaw shifts toward an enhanced THC in the Pacific. Coherently, the reduction in the IT transport is also inferred in paleorecords for glacial periods (Gingele et al., 2001b a; Müller and Opdyke, 2000).

After reviewing these results, it is reasonable to consider a scenario in the past climate where the THC in the Pacific competes to the AMOC over the deepwater formation. On such scenario, the THC in the Pacific demands thermocline waters to flows from the South to the North Pacific through the western boundary current, increasing the contribution of southern water to the IT. The hypothesis is that the change in the hemispheric water source to the IT may change the way the IT impacts on climate. Hence, the hypothetical scenario whereby the Pacific and Atlantic competes over the deepwater formation is considered in the present investigationThe IT impact is explored in such scenario.

\subsection{Objectives}

The present project aims to investigate the IT impact in an alternative climate. For reaching this goal, a series of idealized experiments are employed, so the development and learning process from these experiments are incorporated in the present Thesis. Thus, preceding the IT investigation there are some particular objectives.

Specifically, the Thesis is built on the following stages:

- to build and analyze idealized topographies, until a configuration suite to explore the Indonesian Throughflow;

- to investigate the impact of the Indonesian Throughflow in the alternative climate; 
Chapter 2

\section{Data and Methods}

\subsection{The Coupled Model}

The coupled model used in this study is the Massachusetts Institute of Technology general circulation model (Marshall et al., 1997). The isomorphism between both ocean and atmosphere is explored to create a common hydrodynamic core, as discussed in Marshall et al. (2004), which allows the modeling of both fluids by changing a few parameters. The atmosphere and ocean are integrated forward in a horizontal "cubed sphere" C32, composed by four faces with $32 \times 32$ cells each, yielding a nominal resolution of $2.8^{\circ}$ of latitude (Adcroft et al. 2004). This approach eliminates the meridian convergence problem and assures that the polar regions are resolved with as much confidence as elsewhere.

\subsubsection{The Atmospheric Model}

The atmospheric model is based on a spectral primitive-equation dynamical core and employs the Simplified Parameterization, Primitive Equation Dynamics (Speedy), developed to work with few vertical levels (Molteni, 2003). This physics package is well suite to exploratory climate simulations, with the following modules of parameterization:

\section{Surface Fluxes of Momentum and Energy}

Fluxes are defined by bulk aerodynamic formulas with different exchange coefficients between the land and sea. Coefficients for (sensible and latent) heat fluxes also depend on the vertical gradient of potential temperature between the surface and the lowest model level. 


\section{Convection}

A simplified mass flux scheme is activated when conditional instability is present, and where relative humidity in the planetary boundary layer (PBL) exceeds a fixed threshold. The cloud-base mass flux (at the top of the PBL) is such that the PBL relative humidity is relaxed toward the threshold value. Detrainment occurs only at the cloud-top level (determined by the conditional instability criterion), while entrainment occurs in the lower troposphere if the cloud top is at the highest tropospheric level. The air in the updrafts is assumed to be saturated.

\section{Large-Scale Condensation}

When relative humidity exceeds a fixed threshold, specific humidity is relaxed toward the corresponding threshold value, and the latent heat content removed from the atmosphere is converted into dry static energy.

\section{Cloud Cover}

Cloud cover is determined diagnostically from the maximum relative humidity in an air column including all tropospheric layers except the PBL.

\section{Shortwave Radiation}

Shortwave radiation is reflected by clouds at the top of the troposphere and at the surface; the cloud albedo is proportional to the total cloud cover. The shortwave transmissivity is a function of layer mass, specific humidity, and cloud cover.

\section{Longwave Radiation}

A four-band longwave scheme is used, one for the atmospheric "window" and the remaining four for the absorption by water vapor and carbon dioxide, dependent on the mass and humidity of the layers.

\section{Vertical Diffusion (Shallow Convection)}

Vertical diffusion only acts between the two lowest model layers. Dry static energy and specific humidity are diffused when a conditional instability criterion is satisfied. 
Otherwise, only humidity is diffused, at a slower rate.

\subsubsection{The Ocean Model}

The ocean model is a flat-bottomed $3 \mathrm{~km}$ deep divided by 15 vertical levels, with resolution that spans from $40 \mathrm{~m}$ at surface to $435 \mathrm{~m}$ at bottom. The mesoscale, not resolved, is parameterized by isopycnal diffusion after Gent and Mcwilliams (1990); Redi (1982), with a transfer coefficient of $800 \mathrm{~m}^{2} \mathrm{~s}^{-1}$. The vertical and horizontal eddy viscosity are set to $10^{-3} \mathrm{~m}^{2} \mathrm{~s}^{-1}$ and $3 \times 10^{5} \mathrm{~m}^{2} \mathrm{~s}^{-1}$, respectively. Sea ice is allowed to form and it is controlled by a thermodynamic two-and-a-half layer ice model based on Winton (2000). No sea ice dynamic is used. The solar constant is fixed at $S_{0}=1368 \mathrm{Wm}^{-2}$ and the greenhouse is set to pre-industrial concentration.

The land model is a simple two-layer model with three prognostic variables: temperature, liquid groundwater and snow height.

\subsection{Experiments Designin}

\subsubsection{AquaPlanet}

The AquaPlanet experiment (Fig. 1.5a) is the start point for all further experiments employed here. It consists of a planet with no land, covered by a flat-bottom $3 \mathrm{~km}$ deep ocean. It is initialized whit the averaged temperature and salinity sections extracted from the center Pacific from the World Ocean Atlas 2009 dataset (WOA09) (Locarnini et al. 2010; Antonov et al. 2010).

The Aquaplanet experiment is integrated for 2500 model-years, and the average of the last 50 years is used to create the initial condition for all other simulations.

\subsubsection{Double Drake}

The DDrake experiment initiates with the AquaPlanet final equilibrium, where it is added two one-grid wide land barriers from north pole until $35^{\circ} \mathrm{S}$, separated by $90^{\circ}$ of longitude, as shown by Fig. 1.5c. It configures two northern basins, the small basin and the large basin, resembling the Atlantic and Indo-Pacific sectors. For clarity, the idealized basins are referred to as Atlantic-like and Pacific-like basins. Using the initial condition 
created by the AquaPlanet experiment, the DDrake is integrated for 2500 model-years, and the last 500 model-years are used in the analyses.

\subsubsection{Double Drake Extended}

The experiment Double Drake Extended (DDex) starts from the DDrake, where the western boundary of the small basin is extended until approximately $60^{\circ} \mathrm{S}$. This experiment was first idealized to explore the impact of the mismatch of the latitudinal extension of the land barriers. As discussed later in this thesis, its results were mostly used to tune-up the subsequent experiments.

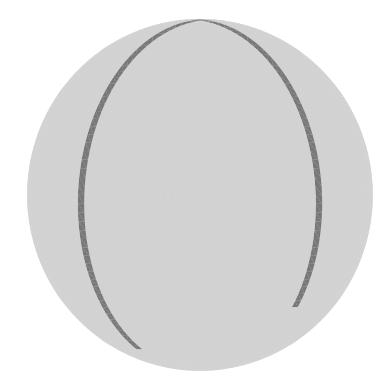

Figure 2.1: Topography of the Double Drake Extended experiment.

The DDex is integrated for 2000 model-years, and the last 50 years are used in the analysis.

\subsubsection{Triple Drake First Version}

The Triple Drake First Version (TDv0) is the first attempt to create an idealized topography with three northern basins, similar to the Atlantic, Indian and Pacific oceans. It starts from the DDex where it is add a third meridional barrier, from the north pole until approximately $44^{\circ} \mathrm{S}$, separated by $90^{\circ}$ of longitude. It allows to investigate the effect of an IT-like, connecting the large and intermediate basins near $10^{\circ} \mathrm{S}$. As discussed later in this thesis, the results from this experiment were compromised by an anomalous circulation in the intermediate basin. Its results however helped to improve the quality of the next topographies. TDv0 was integrated by 1000 model-years, and the last 50 years are used in the analyses. 


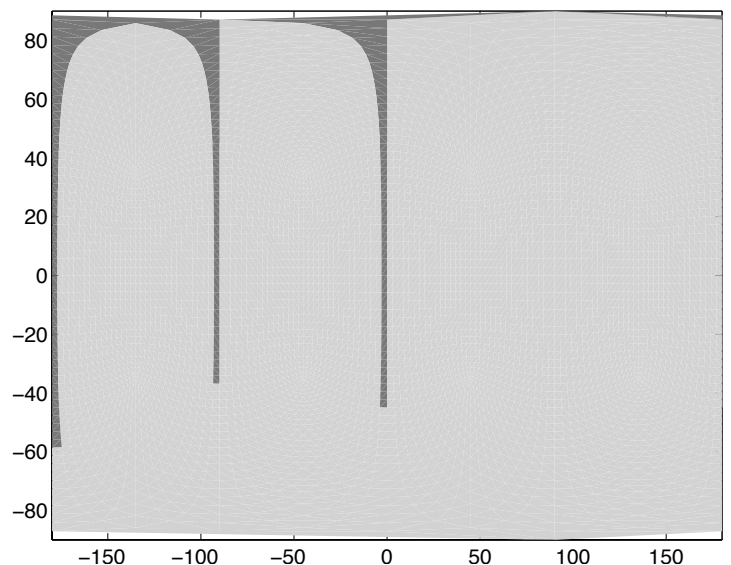

(a) NoITF

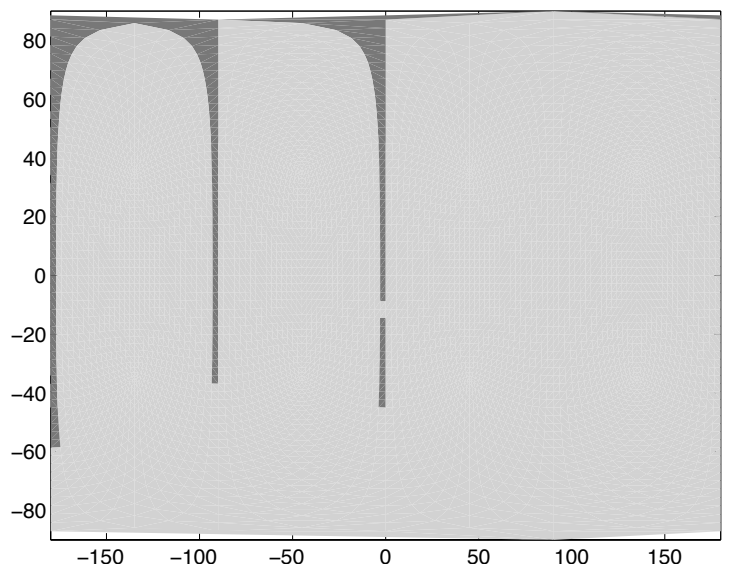

(b) ITF

Figure 2.2: Topography of the Triple Drake First Version experiment without the Indonesian Throughflow (a) and with the Indonesian Throughflow (b).

\subsubsection{Triple Drake}

The Triple Drake experiment (TDrake) evolves from the results of the DDex and TDv0. It was learned from TDv0 the need to restrict the intermediate basin until $20^{\circ} \mathrm{N}$, which is done by a zonal one-grid wide land barrier connecting the second and the third meridional barrier. North of $20^{\circ} \mathrm{N}$ there is no intermediate basin, and the TDrake is the same as the DDrake.

The experience from DDex shows the need to adjust the meridional extension of each land barrier. For the previous experiments the meridional extension was set to be close to their equivalents on the real world, the southern tip of South America, Africa and Australia. On TDrake the meridional extension is set accordingly to the surface wind directions of DDrake, since the the wind field is meridionally shifted in the idealized experiments. The southern tip of the first, second and third meridional barrier are them set to approximately $44^{\circ} \mathrm{S}, 35^{\circ} \mathrm{S}$ and $38^{\circ} \mathrm{S}$, respectively.

The TDrake set of experiments is composed by four idealized topographies (TD00, TD01, TD10 and TD11). They differ from one to another by specific details in the topography. These differences regard the meridional extent of the African-like continent and the presence or absence of a passage on the third meridional barrier. By moving the Africa-like continent the Agulhas Leakage-like is blocked (TD00 and TD01) or allowed (TD10 and TD11). The passage in the third meridional barrier simulates the IT, which is blocked (TD00 and TD10) or open (TD01 and TD11). Thus, the AL and the IT are 
represented by the first and second binary indices in the experiment names, respectively.

All Triple Drake experiments were integrated for 1500 model-years, and the last 500 are used in the analyses.

\subsubsection{Triple Drake - TD00}

The TD00 (Fig. 2.3), with no AL or IT, has meridional barrier ending at $44^{\circ} \mathrm{S}, 35^{\circ} \mathrm{S}$ and $38^{\circ} \mathrm{S}$. The AL is prevented to occur by a viscous choking, as the end termination of the African-like continent is close enough to the zero curl of the wind stress. One should notice that the high eddy viscosity implies in a thick Munk boundary layer, compared to the gap between the African-like tip and the maximum westerlies.

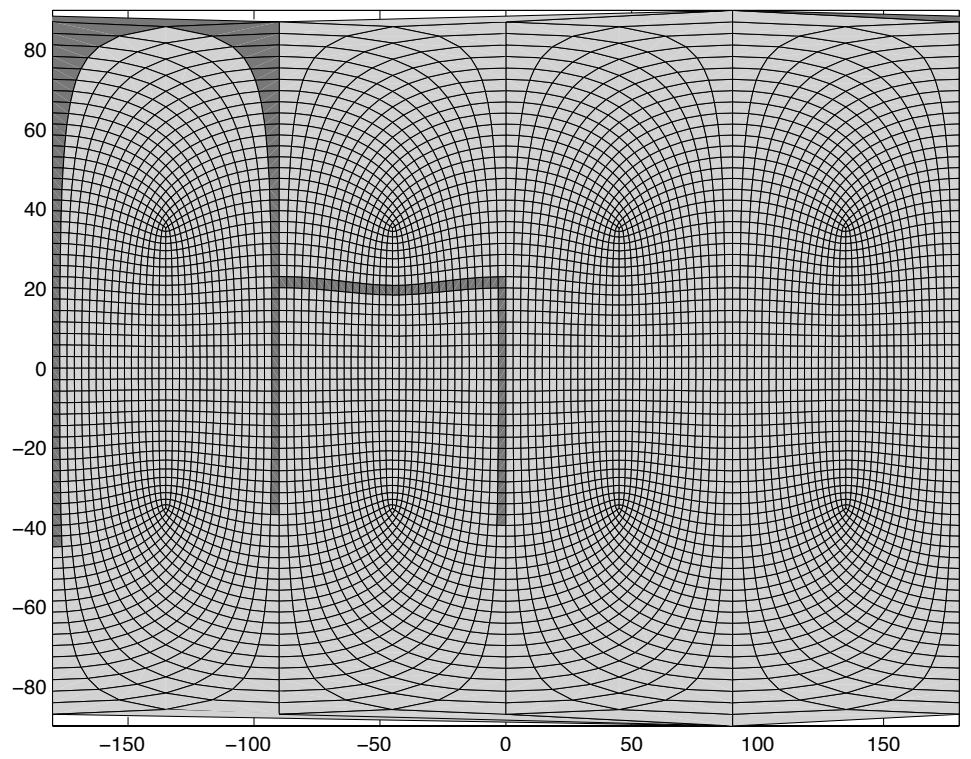

Figure 2.3: Idealized topography of the TD00 experiment.

\subsubsection{Triple Drake - TD10}

In order to allow the $\mathrm{AL}$ to occur, the meridional extension of the second barrier is reduced until $30^{\circ} \mathrm{S}$ (Fig. 2.4). It opens a gap sufficiently large between its southern tip and the zero curl of the wind stress that allows the input of thermocline water from the Indian-like to the Atlantic-like basin. The IT remains closed. 


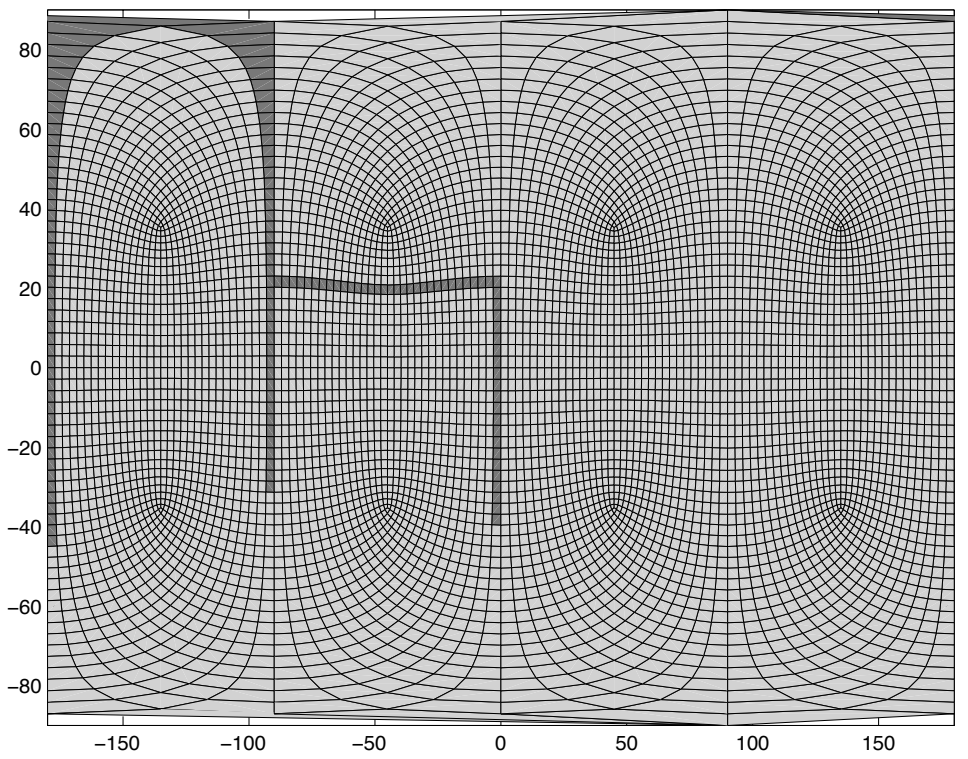

Figure 2.4: Idealized topography for the TD10 experiment.

\subsubsection{Triple Drake - TD01}

The TD01 is similar to TD00, but the IT passage is opened (Fig. 2.5). The IT, in high resolution simulations, describes complex paths before entering the final channels of the Indonesian Gateways, which starts at $10^{\circ} \mathrm{N}$ approximately. In order to introduce a slight complexity in this sense, the idealized IT passage is build as a channel of $1 \mathrm{~km}$ deep that opens in the Pacific-like at approximately $10^{\circ} \mathrm{N}$ and in the Indian-like at $10^{\circ} \mathrm{S}$, approximately.

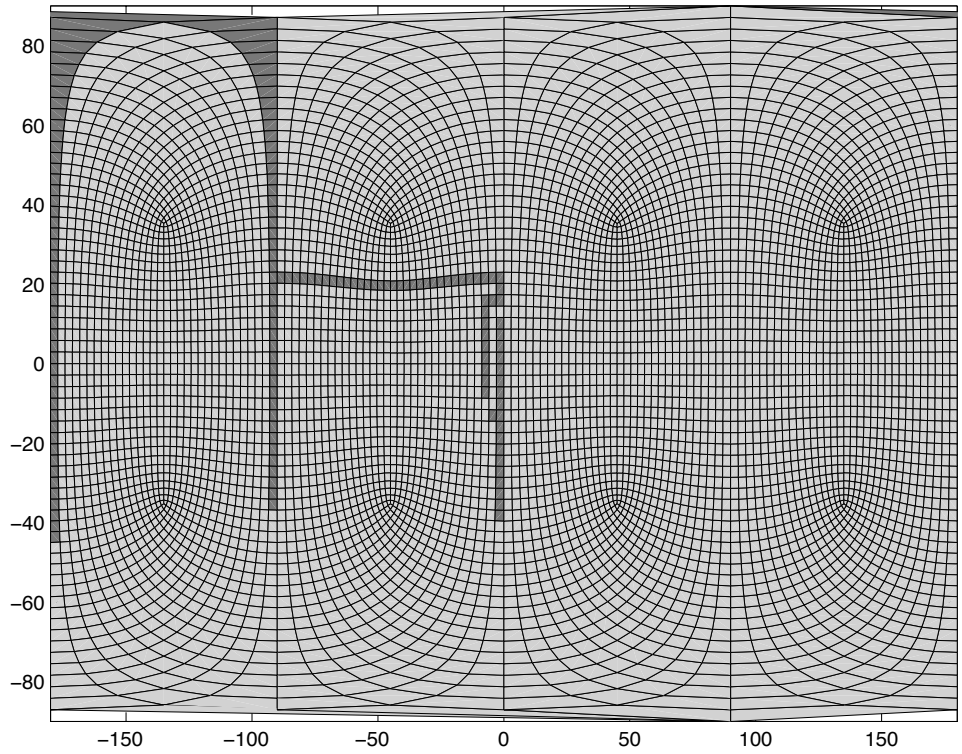

Figure 2.5: Idealized topography for the TD01 experiment. 


\subsubsection{Triple Drake - TD11}

The TD11 (Fig. 2.6) is similar to the TD10 and TD01, combining the AL and the IT passage.

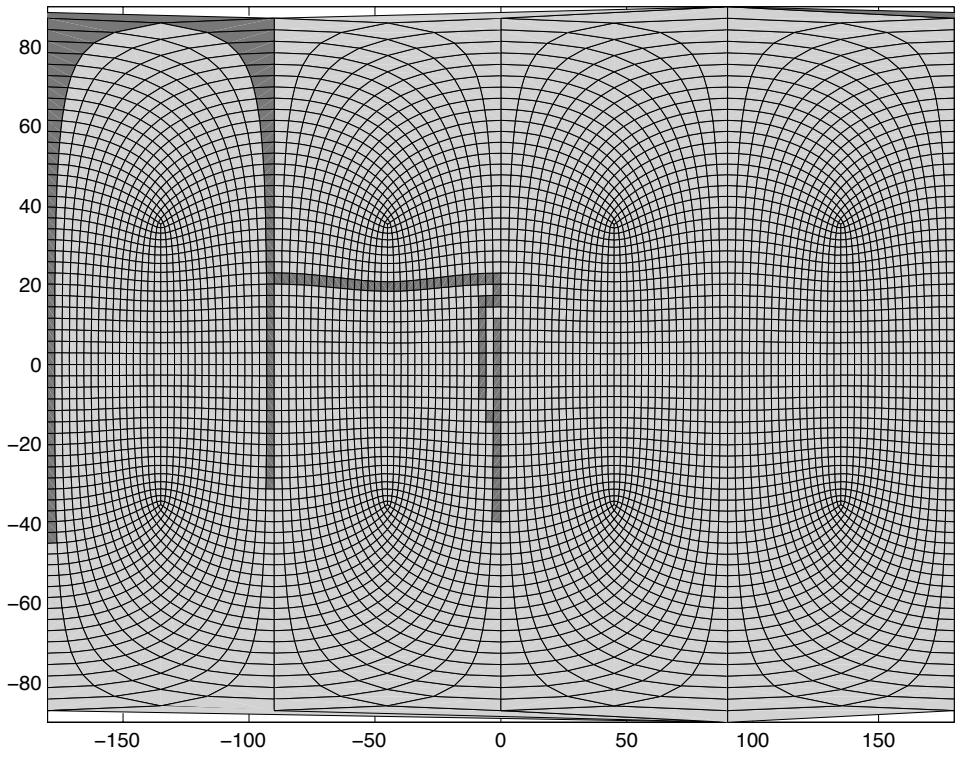

Figure 2.6: Idealized topography of the TD11 experiment. 
Chapter 3

\section{Results and discussion}

\subsection{The Aquaplanet Experiment}

The goal of using idealized experiments, such as the Aquaplanet, is not to simulate accurately the present or past climate. Rather, it is to study the details of a coupled system in a simplified framework, whereby the main aspects of climate are present while most of its complexity is reduced. The Aquaplanet is the first step on a series of experiments along this study. Although the final analyses do not focus on this experiment, Aquaplanet configures the initial condition to the further experiments. Thus, this experiment has to be validated against previous studies of the Aquaplanet climate, ensuring the next experiments lies on a solid basis.

\subsubsection{The Aquaplanet's Mean State}

The ocean circulation in the Aquaplanet is quite different from the real ocean, although the atmospheric circulation is already reminiscent of the observations. The atmospheric MOC (Fig. 3.1 $a$, top) shows a Hadley cell centered at the equator, followed by the Ferrel cells in mid-high latitudes, and the Polar cells extending until $\pm 60^{\circ}$ latitude. The MOC in the ocean (Fig. 3.1 a, bottom) is symmetric to the prevailing winds above, entirely controlled by the eddy-driven and wind subduction, with no THC driven convectively near the poles. 


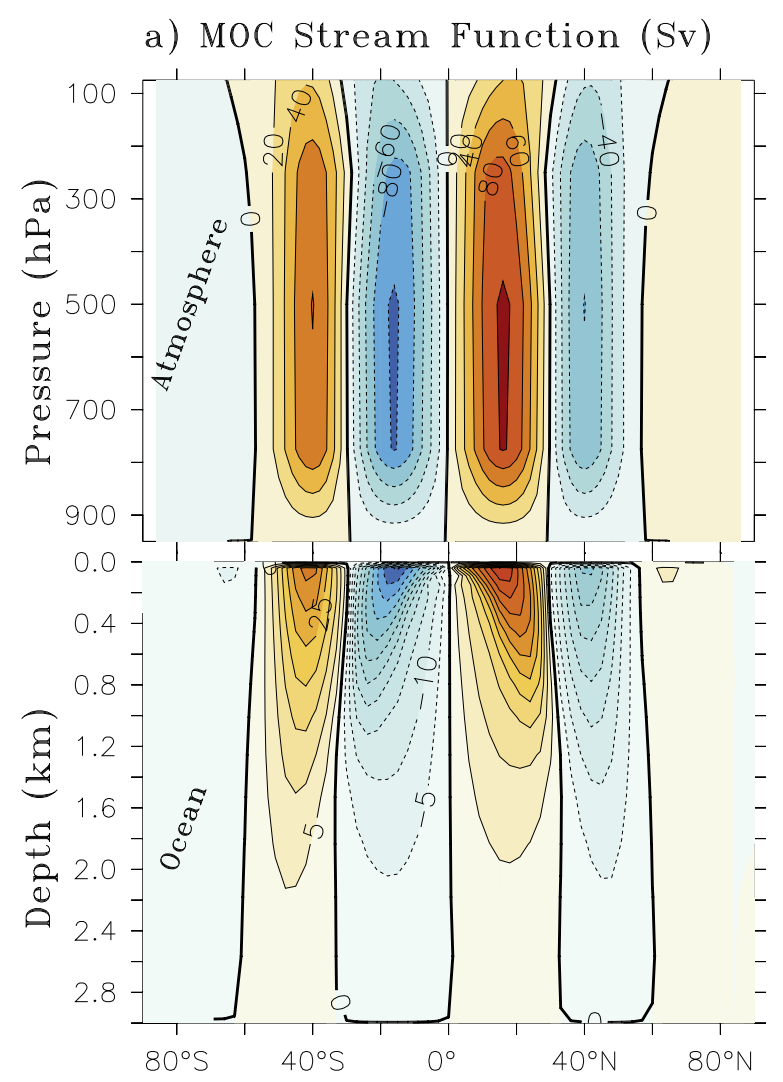

b) Potential Temperature $\left({ }^{\circ} \mathrm{C}\right)$

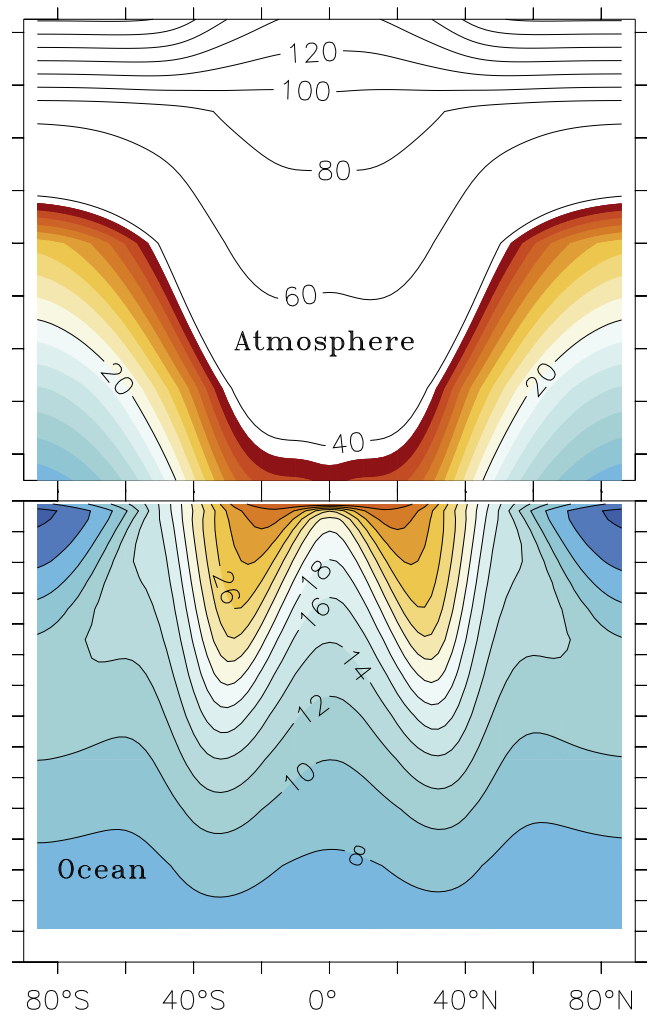

Figure 3.1: The Aquaplanet's eulerian meridional overturning stream function for atmosphere (a, top) and ocean (a, bottom), in Sv, and the zonal mean potential temperature for the atmosphere (b, top) and ocean (b, bottom), in ${ }^{\circ} \mathrm{C}$.

The potential temperature (Figs. $3.1 b$ ) is meridionally symmetric in both fluids. The large scale pattern of oscillation in the ocean temperature is controlled by the Ekman pumping, set by the surface stress, which upwells the colder water around the equator and $\pm 60^{\circ}$, while downwelling occurs around $\pm 30^{\circ}$. Salinity (not shown) is also meridionally symmetric and affected by the Ekman pumping.

The present results of the Aquaplanet experiment is in accordance to the overall results from Marshall et al. (2007), where the main state and variability of the Aquaplanet are deeply discussed. However, the solution obtained here follows the results from Ferreira et al. (2010), showing a warmer climate with no sea-ice on the poles. Ferreira et al. (2010) has described three different equilibria for the Aquaplanet, using the same set of parameters: a cold state in which a polar sea-ice cap extends into the midlatitudes; a warm-state, which is ice-free; and a completely sea ice covered "snowball state". The warm-state equilibrium naturally emerges on the present Aquaplanet and is maintained on the further experiments. The overall mean state expected for an Aquaplanet experiment is 
thus achieved, demonstrating the local implementation of the MITgcm, as well the model configuration, has consistent results, and further experiments can be explored.

\subsection{The Double Drake Experiment}

\subsubsection{The DDrake's Mean State}

Given the overall results of the Aquaplanet analyzed earlier, the most relevant aspects introduced by the DDrake are the meridional and the zonal asymmetries, which approximates this idealized climate to the real Earth's climate.

\subsubsection{Temperature (Figs. 3.2 and $3.2 b$ )}

The changes in circulation lead to interhemispheric and a zonal asymmetries on SST and surface air temperature. The northern Atlantic-like is $2{ }^{\circ} \mathrm{C}$ warmer than the northern Pacific-like, while the northern latitudes are warmer by, in average, $7^{\circ} \mathrm{C}$ than the southern latitudes. In the tropical region, an oceanic warm pool is formed on the western Pacific-like, which is also present in the surface air temperature.

\subsubsection{Surface Salinity and Freshwater Flux (Figs. $3.2 c$ and $3.2 d$ )}

At the latitudes where the ocean is blocked, the Sverdrup balance creates gyres that mix ocean properties as heat and salt. The resulting SSS is then affected by the ocean currents, increasing the salinity over areas of negative freshwater forcing. The North Atlantic-like is saltier than the North Pacific-like, which is in agreement to the higher negative freshwater forcing on the Pacific-like north of $40^{\circ} \mathrm{N}$. Additionally, due to the zonal extension of the Pacific-like being three times the Atlantic-like, the surface waters are longer exposed to the freshwater forcing on the Pacific-like.

\subsubsection{Surface Wind and Currents (Figs. 3.2 e and $3.2 f$ )}

An analogous to the Antarctic Circumpolar Current (ACC) of our modern climate is established between $60^{\circ} \mathrm{S}$ and $40^{\circ} \mathrm{S}$. This oceanic jet is in accordance with the surface wind forcing, which reverses its direction south of approximately $60^{\circ} \mathrm{S}$ under the Polar cell. As there is no ice cap on the south pole, the Ekman transport piles water on South Pole and 
creates a local minimum in ocean surface elevation around $65^{\circ} \mathrm{S}$, geostrophically coherent with the westward currents poleward of $65^{\circ} \mathrm{S}$.

a) DDrake - $\mathrm{SST}\left({ }^{\circ} \mathrm{C}\right)$

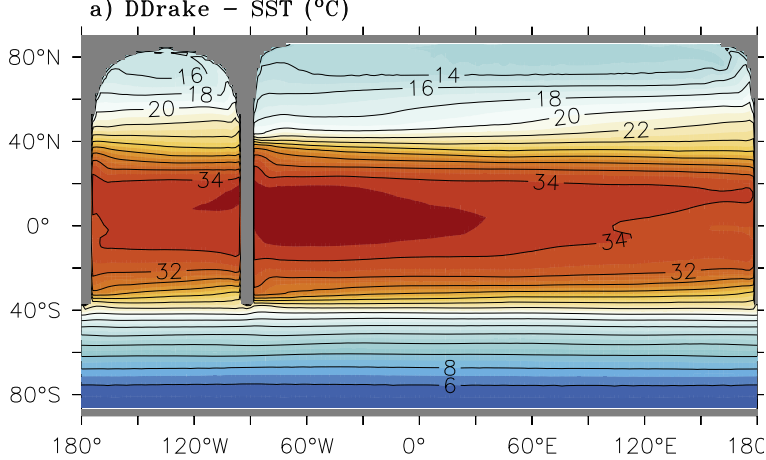

c) Drake - SSS (Psu)

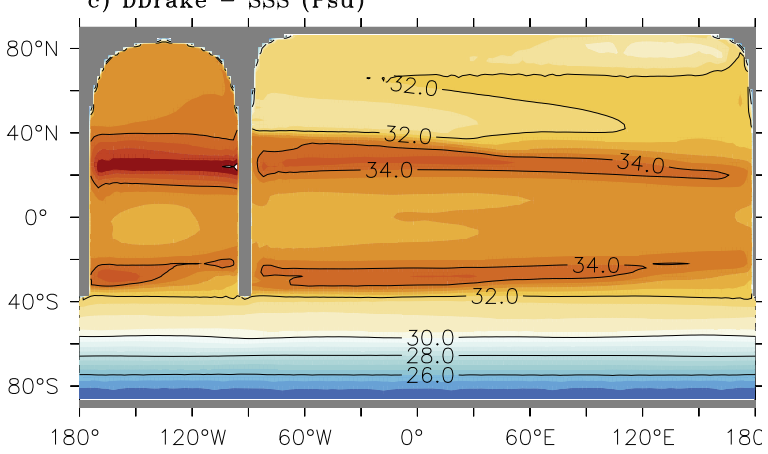

e) DDrake - Currents $0-400 \mathrm{~m}\left(\mathrm{~cm} \mathrm{~s}^{-1}\right)$

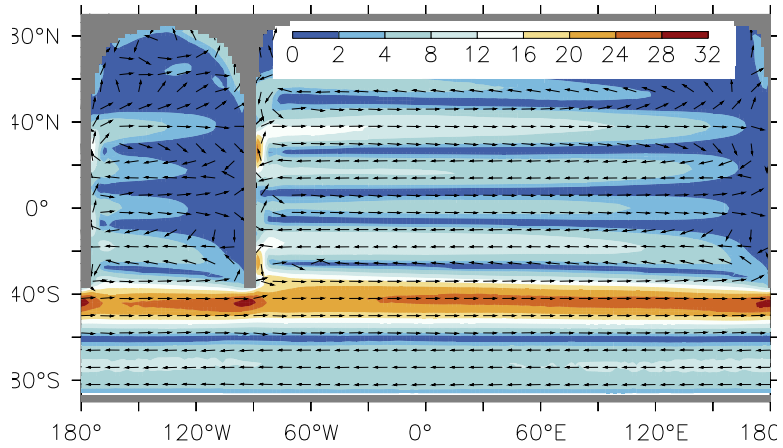

g) D Drake - Ocean MOC Stream Function (Sv)

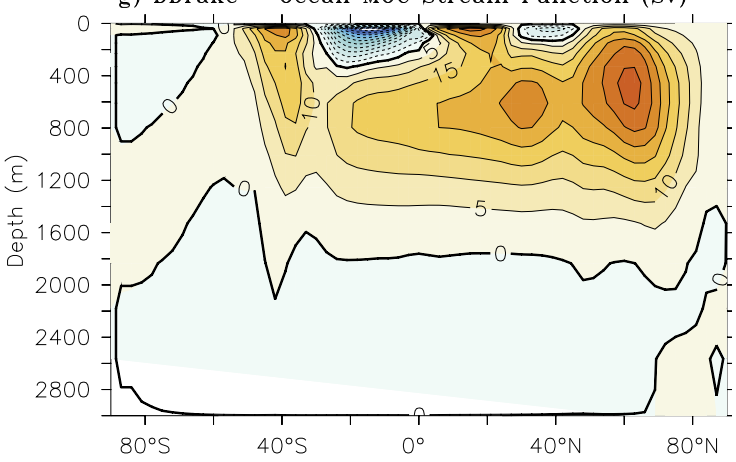

b) DDrake - Sup. Air Temp $\left({ }^{\circ} \mathrm{C}\right)$

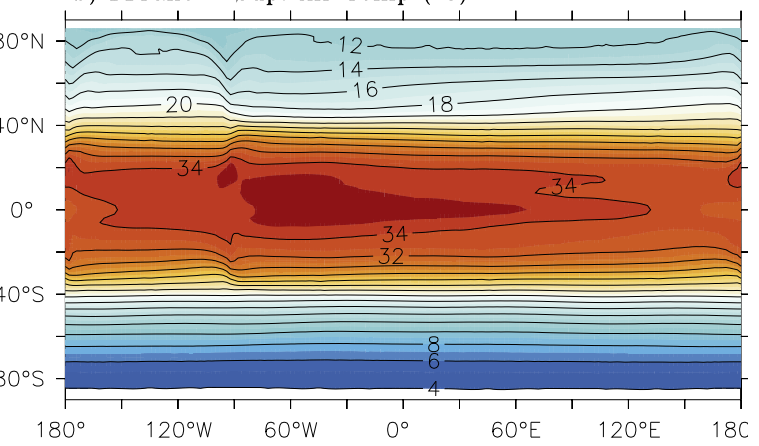

d) DDrake - Freshwater Flux (mm day $\left.{ }^{-1}\right)$

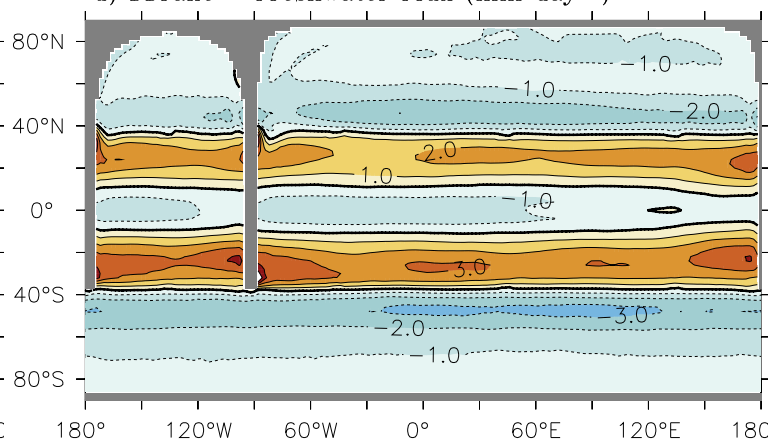

f) DDrake - Superficial winds $\left(\mathrm{m} \mathrm{s}^{-1}\right)$

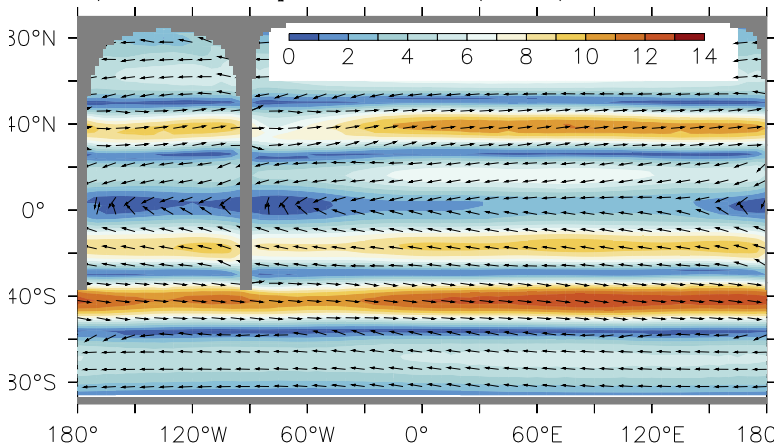

h) DDrake - Atm. MOC Stream Function (Sv)

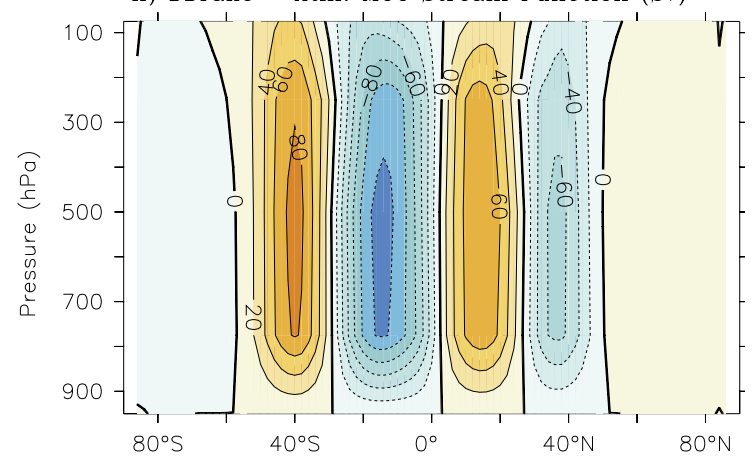

Figure 3.2: Mean state for the DDrake experiment. 

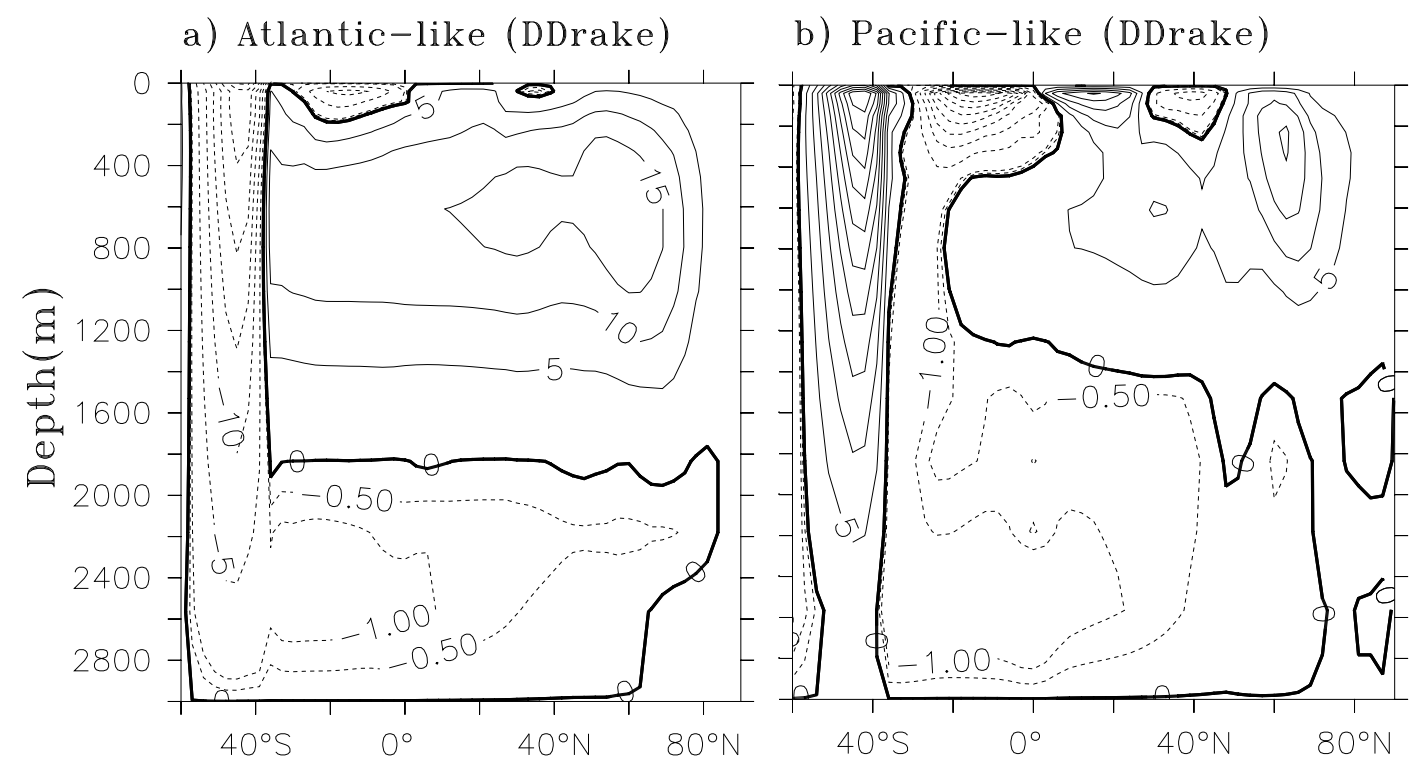

Figure 3.3: Meridional overturning stream function for the Atlantic-like (a) and Pacific-like (b) basins of DDrake. Units in Sv.

\subsubsection{Global Overturning Circulation (Figs. $3.2 \mathrm{~g}$ and $3.2 \mathrm{~h}$ )}

The global ocean MOC loses its meridional symmetry and presents a strong interhemispheric cell that reaches $1800 \mathrm{~m}$ deep, which, although the differences in the mean ocean depth, is remarkable similar to the MOC of the real ocean. The atmospheric MOC of DDrake shows the meridional cells to change in strength and position from the Aquaplanet's equilibrium. The latitude position where the northern and southern cells of the Hadley cell encounters, at low levels, used here as an approximation to the ITCZ position, is positioned north of the equator, as the observed ITCZ (Marshall et al., 2014).

\subsubsection{Ocean Deep Convection}

The deep convection index is mostly confined in the northern Atlantic-like in DDrake (Fig. 3.4) in agreement to the results from Ferreira et al. (2010), although here there is still a sinking region in the northern Pacific-like. The deep convection index shows the fraction of time the convective adjustments are active on each grid cell. 


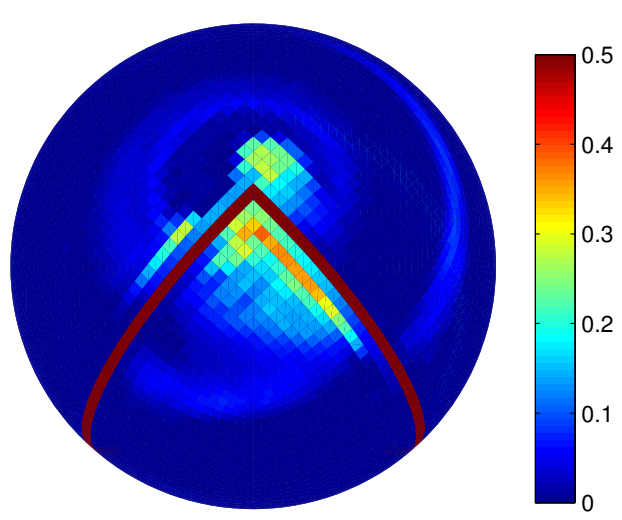

Figure 3.4: The convection adjustment Index averaged on the upper $700 \mathrm{~m}$. It shows the fraction of time that the convective adjustment is active on each grid cell.

The deep convection leads to asymmetries on the THC between basins, which is evidenced by computing the meridional overturning separately in the Atlantic-like and Pacific-like basins (Figs. $3.3 a$ and $b$ ). In the Atlantic-like, the meridional overturning is similar to the AMOC (Figs. $3.3 a$ ), with deep convection in northern latitudes and upwelling in the southern hemisphere. The deepwater flows southward above a bottom water formed on the ACC-like region, which enters the basin through the bottom and returns around 2000 m depth. This is similar to the deeper AMOC cell formed by the Antarctic Bottom Water $(\mathrm{AABW})$ and its return flow in the real world. In the Pacific-like, the overturning is reminiscent from the Atlantic-like, but rather weaker and shallow. There is deep convection on the northern Pacific-like, but most of it recirculates around $60^{\circ} \mathrm{N}$. The presence of an interhemispheric overturning in the Pacific-like resembles the solution from Sijp and England (2009), where the Agulhas Leakage is blocked by an equatorward shift of the South Hemisphere westerlies maximum. In the DDrake, the leakage is blocked by a viscous choking. In both cases, an asymmetric overturning cell develops in the Pacific, but shallow and weaker than on the Atlantic.

The overturning circulation in the Atlantic-like (Fig. 3.3 a) leads to a zonal mean salinity similar to the observations. Fig. 3.5 compares the zonal mean salinity anomaly in the Atlantic between DDrake and WOA09. The zonal mean anomaly is computed by subtracting the basin averaged from the zonal averaged salinity. The anomaly is used rather than the salinity itself since the total salt budget in DDrake is smaller than the observations. This results from the first initial condition of the Aquaplanet, which is further used in all other experiments. This first initial condition was extracted from a meridional 
section from central Pacific (from WOA09), instead a global averaged salinity section. It implies a reduction in the total salt budget in DDrake. Thus, the basin average salinity is subtracted from the zonal mean salinity, so the results could be compared. The results (Figs. 3.5) show the salinity to present a spatial field similar to the WAO09, with a North Atlantic-like Deep Water (NADW-like) formed on the northern latitudes, extending toward the southern hemisphere above an Antartic-like Bottom Water (AABW-like), which enters the basin from its southern entrance. The Antartic-like Intermediate Water (AAIW-like) signature is not observed as far as at the equator, where the South Atlantic-like Central Water (SACW-like) is almost erased. Despite the differences, naturally expected for such idealized experiment, these results demonstrate that the DDrake's Atlantic-like dynamics work in a very similar way to the Atlantic, not only in terms of circulation, but also regarding the water masses involved.

a) DDrake Salinty Anom (Psu); Mean=33.3Psu

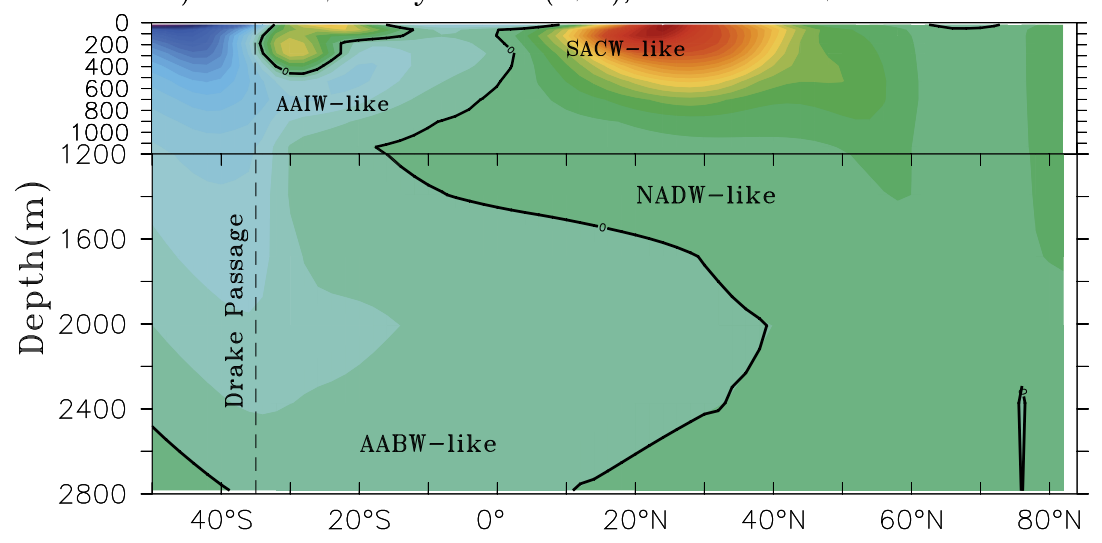

b) WOA09 Salinty Anom (Psu); Mean=34.9Psu

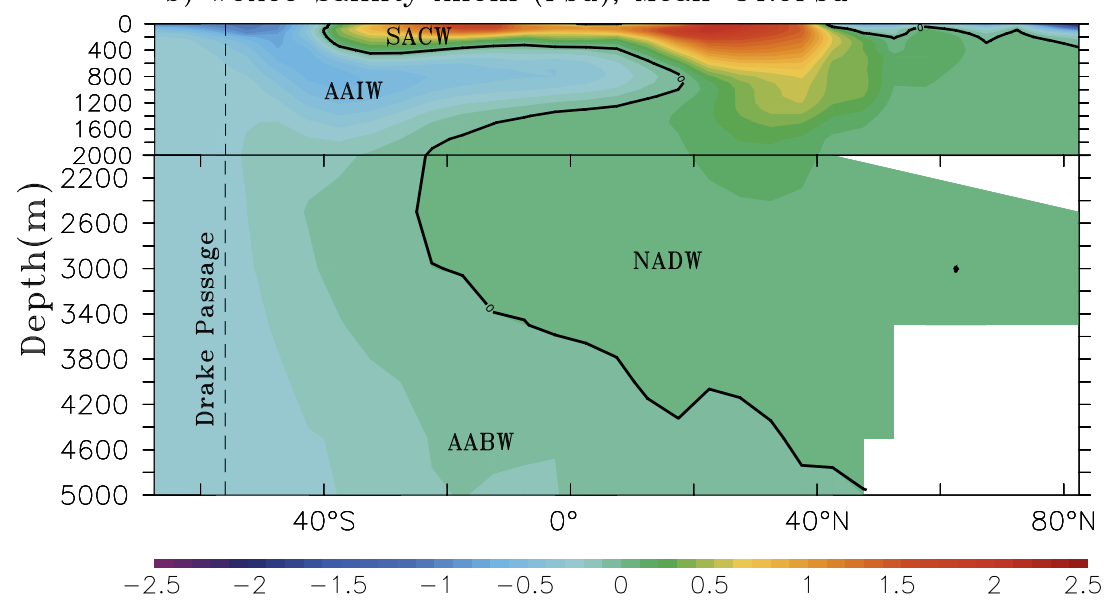

Figure 3.5: The zonal salinity anomaly over the Atlantic for DDrake (a) and from WOA09 (b). The anomaly is computed by subtracting the zonal mean from the basin average. Units in Psu. 


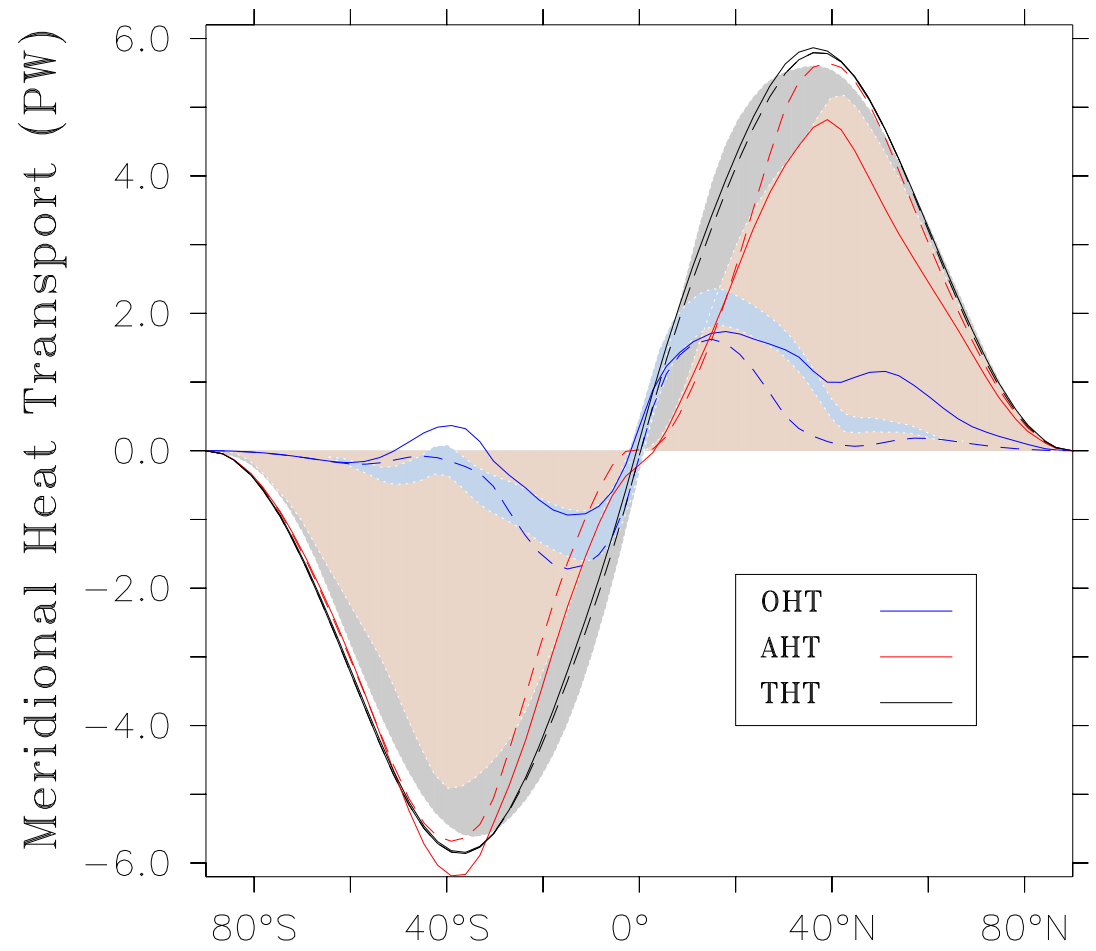

Figure 3.6: The meridional heat transport in the ocean (blue), atmosphere (b) and the total heat transport (black), for experiments Aquaplanet (dashed), DDrake (line) and the estimative from Trenberth and Caron (2001) (colored background). Units in $P W$. The observed OHT is filled regarding its error range.

\subsubsection{Meridional Heat Transport (Fig. 3.6)}

By comparing the meridional heat transport of the Aquaplanet and the DDrake experiments to the estimates from Trenberth and Caron (2001), it is striking that the gross characteristics are so similar to one another, regarding their magnitudes and pattern. However, after a closer inspection, it is seen that despite that the THT changes little, significant differences in the partition between ocean and atmosphere are evident. The inter-hemispheric THC (Fig. $3.2 \mathrm{~g}$ ) organizes the OHT and leads to a positive northward OHT across the equator of about 0.35 PW (inside the observation errors). As mentioned, the ITCZ position shifts northward, as expected from the AHT compensation to the OHT (Marshall et al., 2014). Comparing to the estimative, two oddly enhanced positive OHT are found around $40^{\circ} \mathrm{S}$ and $50^{\circ} \mathrm{N}$. Positive values of $\mathrm{OHT}$ at $40^{\circ} \mathrm{S}$ are possible in observation, but on the DDrake it is larger in magnitude and meridional coverage. The positive OHT around $50^{\circ} \mathrm{N}$ reflects the THC circulation, which is still active on higher latitudes in the absence of great land-masses. The AHT is modified in order to compensate the OHT, keeping the THT little changed. 


\subsubsection{Remarks on the DDrake Mean State}

The DDrake experiment introduces asymmetries that brings the Aquaplanet's climate toward the observations. The warmer northern Hemisphere, the saltier Atlantic-like and the deep sinking most concentrated on its northern latitudes, as also its strong THC, gives to the DDrake an equilibrium reminiscent of the observed climate. The success of using idealized experiments to address issues of the real climate, such as the Indonesian Throughflow, depends on their ability to represent the gross characteristics of climate, which is promisor in DDrake. Before continuing to increase the topography's complexity, necessary to investigate the Throughflow, the DDrake's variability is investigated.

\subsubsection{DDrake Variability}

The strength of the AMOC (or the AMOC Index) is usually defined as the maximum of zonal integrated annual mean overturning streamfunction in the Atlantic at $40^{\circ} \mathrm{N}$. The strength of the DDrake Atlantic-Like MOC (also referred to as AMOC) is defined as such, but regarding the small basin. For simplicity, the AMOC Index is hereinafter referred to as AMOC. The AMOC variability from a realistic simulation (Zhang, 2008) presents a standard deviation (SD) of $1.8 \mathrm{~Sv}$, while the DDrake's AMOC has a SD of 0.6 Sv. However, observation suggests the real AMOC Index SD might be smaller than the simulated $(\mathrm{SD}=1.8 \mathrm{~Sv}$; Zhang, 2008). Despite the smaller amplitude of the AMOC variability in DDrake, the goal in this section is to investigate the mechanism that drives its decadal variability on such idealized experiment, rather than reproduce the correct amplitude itself.

The AMOC for the DDrake (Fig. 3.7 a) and its wavelet analysis (Fig. 3.7 b) reveals that its variance is scattered distributed onto interannual variations and onto more consistent decadal variabilities, which spans from one to three decades approximately. In simulations with realistic topography the AMOC Index is only a good measure of the AMOC variability at timescales of decades or longer (Vellinga and $\mathrm{Wu}, 2004$ ), thus the variabilities with timescales shorter than the interdecadal are filtered by a Hanning smoother with a 10year-window (Press et al., 1986). 

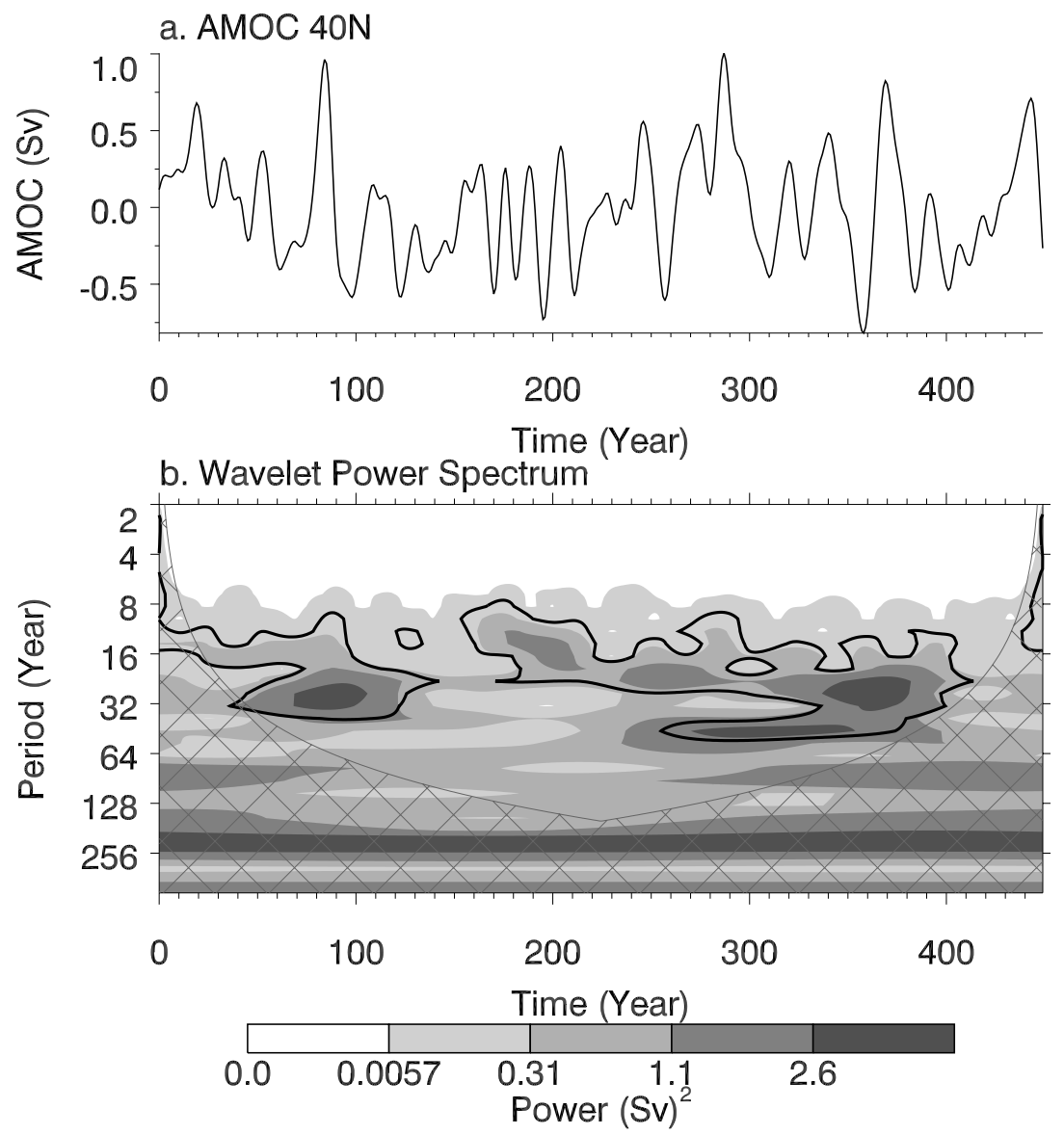

Figure 3.7: (a) The OHT time series, detrended and smoothed by a 10-year moving mean, in PW. (b) The wavelet power spectrum. The cross-hatched region is the cone of influence of the time series edges. The black contour encloses the regions where the variance exceeds the $95 \%$ confidence level of a red-noise process. More details about the wavelet analyses are found on Torrence and Compo (1998).

From considerations of mass conservation, the spin-up of the AMOC requires more surface waters to undergo into the deep ocean through the deep convection sites. Hence the vertical motion $(w)$ over these areas should also capture the AMOC variability. Fig. 3.8 compares the mean convective adjustment index at $65 \mathrm{~m}$ (shaded colors) to the areas of strong downwelling at $700 \mathrm{~m}$ (black contour), using an empirical threshold of $w<$ $-5 \times 10^{-6} \mathrm{~ms}^{-1}$ to define the strong downwelling itself. The intense vertical motion is found in two main regions (black contour on Fig. 3.8): one smaller north of $70^{\circ} \mathrm{N}$ off the western boundary (A1), and the other spreading from $50^{\circ} \mathrm{N}$ to $90^{\circ} \mathrm{N}$ off the eastern boundary (A2). The area-averaged $w$ over A1 and over A2, at $700 \mathrm{~m}$, is set as a proxy of the deep convection efficiency to produce vertical motion. 


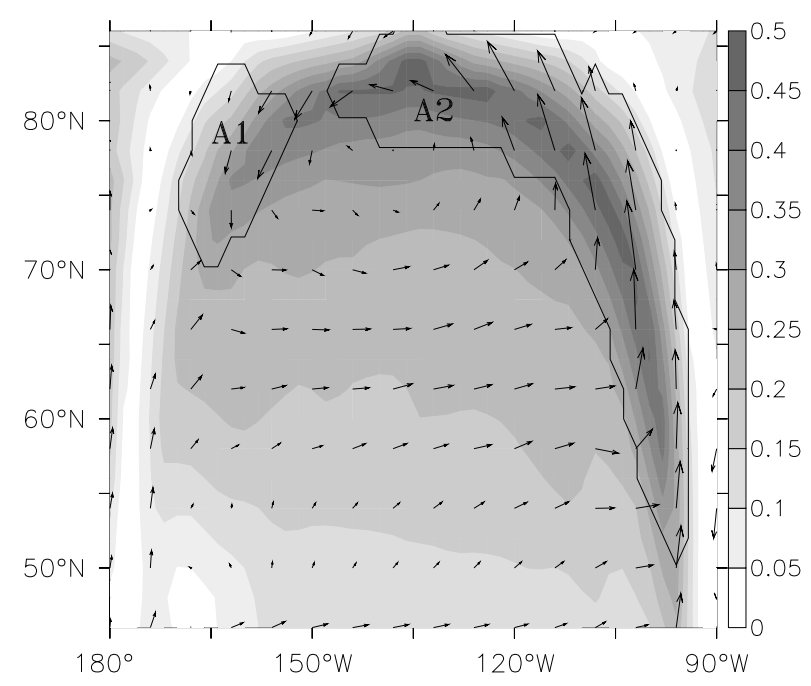

Figure 3.8: The convection adjustment index at $65 \mathrm{~m}$ (grayscale) and the regions (A1 and A2) where $w<-5 \times 10^{-6} m s^{-1}$, at $700 \mathrm{~m}$ (black contour). The vectors shows the averaged currents between 0-150 m.

It is found the convection over A1 and A2 to be intrinsically different. The A1 region comprehends the convergence of the upper western boundaries currents (Fig. 3.8) and reflects the changes in the wind strength at the sea surface. Additionally, most of its downwelling recirculates around $60^{\circ} \mathrm{N}$. Our interest, however, regards the deep convection associated with the salinity-driven changes on buoyancy, as is the salinity that controlls the deep convection in DDrake (Ferreira et al., 2010). Thus the investigation is focused on the variability of $w$ over A2.

Two composites of the AMOC are performed by sorting the AMOC in two groups, regarding the strength of the convection over A2 (defined above as the area-averaged $w$ over A2 at $700 \mathrm{~m}$ ). Specifically, one group contains the AMOC averaged over periods when the deep convection over A2 exceeds 1.5 times its SD. The other group is similar, but for periods when the deep convection over A2 is less than -1.5 times its SD. The departure from these two composites is shown in Fig. 3.9. The threshold of 1.5 times the SD is defined as it gives similar number of events to be computed for both composites. The differences between the two composites are remarkably similar to the third Empirical Orthogonal Function (EOF) of the AMOC (Fig. 3.9), computed on the northern hemisphere, which explains $15.5 \%$ of the AMOC variance. Comparing the convection over A2 to the expansions coefficients of the EOF 3 a correlation of 0.63 is found, addressing the sinking over A2 to the variability captured on EOF 3. 


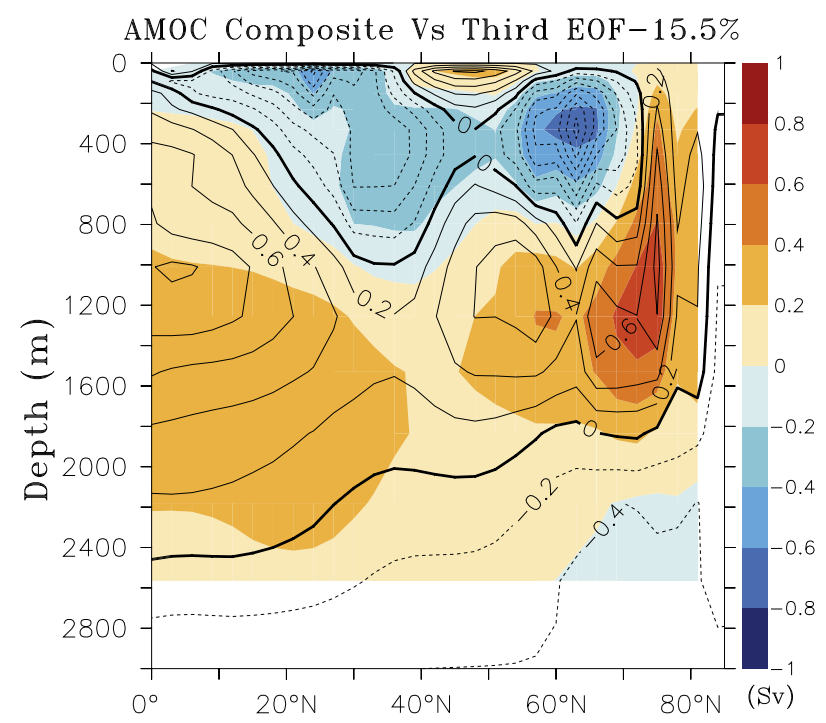

Figure 3.9: Comparison between the composite of the AMOC (colored) and the EOF 3 of the AMOC (contour). The composite is computed by averaging the AMOC for strong and weak events of deep convection over A2, separately, using a threshold of \pm 1.5 times its standard deviation, and taken the departure between the strong minus weak composites. Units in Sv.

The buoyancy in the northern Atlantic-like is mostly driven by salinity, hence it is checked the correlation between the convection over A2 and the SSS (Fig. 3.10). The convection is most negatively correlated to the SSS over A2, reaching a coefficient of - 0.6 on the southeast sector of A2. By comparing the spatial distribution of this correlation to the upper currents on Fig. 3.8, it suggests the correlation of convection with the SSS is associated to the salinity transported by the surface currents, which is investigated latter in this section. In advance, the salinity anomalies are indeed advected by the mean circulation until northern latitudes rather than originated locally by surface fluxes.

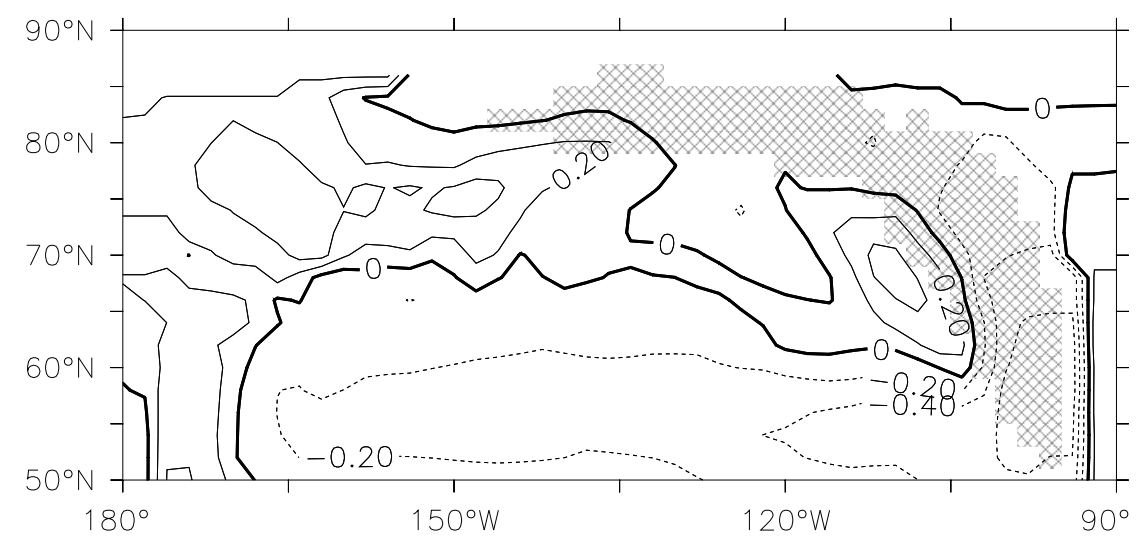

Figure 3.10: Linear correlation between the SSS and the deep convection over A2. 


\subsubsection{Salinity Anomalies and Freshwater Flux}

The salinity budget variations on an overturning circulation cycle show that the advective transport dominates the salinity flux north of $35^{\circ} \mathrm{N}$, while the surface fluxes dominate the salinity anomalies in the tropical regions (Vellinga and $\mathrm{Wu}, 2004$ ). The correlation between the freshwater flux and the sea surface salinity anomaly (SSA) over A2 is weak $(<0.2)$, suggesting the surface forcing can also be neglected on controlling the SSS in high latitudes in the DDrake. In that case, the salinity anomalies over A2 are formed elsewhere and then transported towards higher latitudes. The Fig. 3.11 shows the hovmoller of the zonally averaged SSA in the Atlantic-like basin. There is a clear pattern of propagation, and those anomalies that reach high latitudes are originated between $25^{\circ} \mathrm{N}-45^{\circ} \mathrm{N}$, approximately, from where they move northward with time.

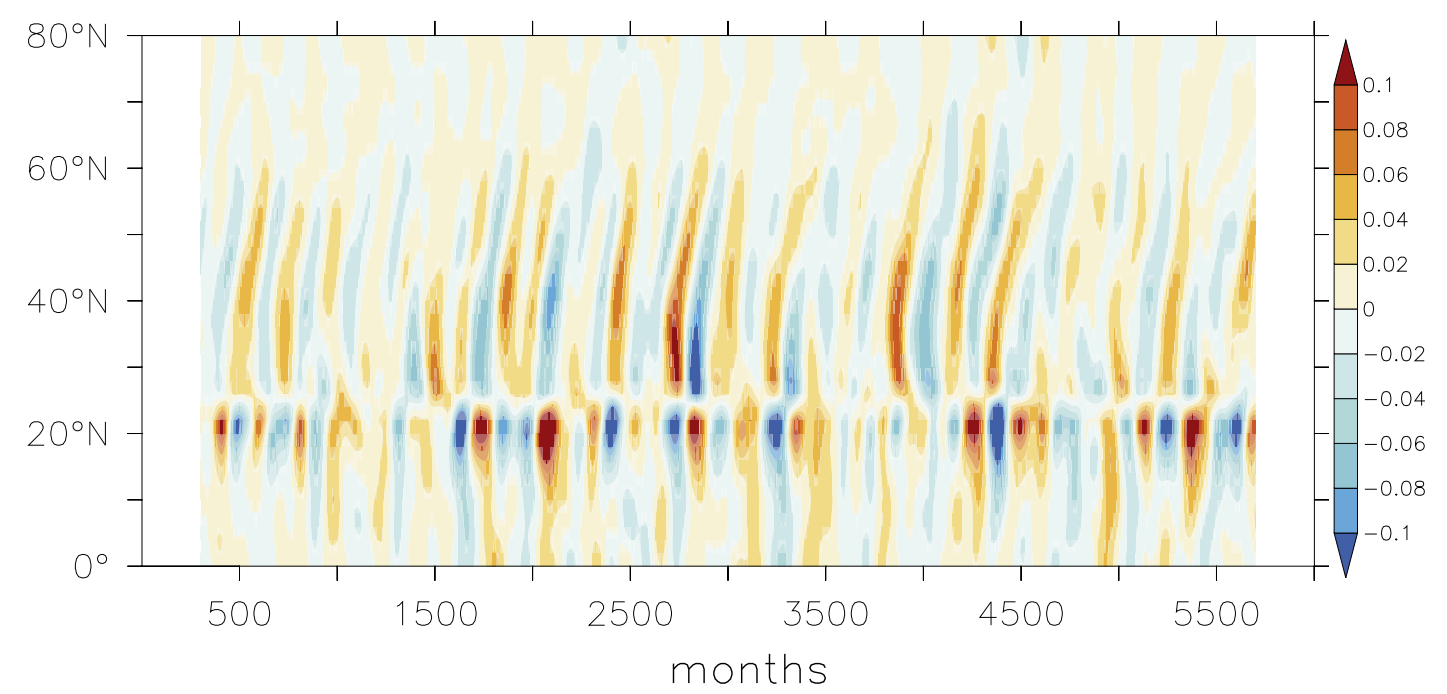

Figure 3.11: Hovmoller of the zonally averaged SSA over the Atlantic-like basin. Units in Psu.

Over the 500 years of simulation, the northward propagation of SSA present a persistent pattern of spatial propagation, coherently with the surface mean currents. In order to show this propagation signal, a composite is made by averaging the SSA in the Atlantic-like basin when the zonally averaged $\mathrm{SSA}$ at $30^{\circ} \mathrm{N}$ reaches a local Maxima $\left(\mathrm{t}_{M}\right)$. The SSA is also averaged for $\mathrm{t}_{M}-4 \mathrm{yr}, \mathrm{t}_{M}+4 \mathrm{yr}$ until $\mathrm{t}_{M}+16 \mathrm{yr}$, with $4 \mathrm{yr}$ intervals (Fig. 3.12). The SSA are formed in the western part of the small basin, between $25^{\circ} \mathrm{N}-45^{\circ} \mathrm{N}$, approximately (Fig. $3.12 a$ ), and propagate eastward within the subtropical gyre, creating a zonal-wide anomaly (Fig. $3.12 b$ ). After spreading over the small basin, they propagate northeastward (Figs. $3.12 c$ and $d$ ), and around $60^{\circ} \mathrm{N}$ the eastern sector of the anomalies is advected northward 
by the eastern boundary current, describing a counterclockwise path over the A2 (Figs. $3.12 e$ and $f)$.
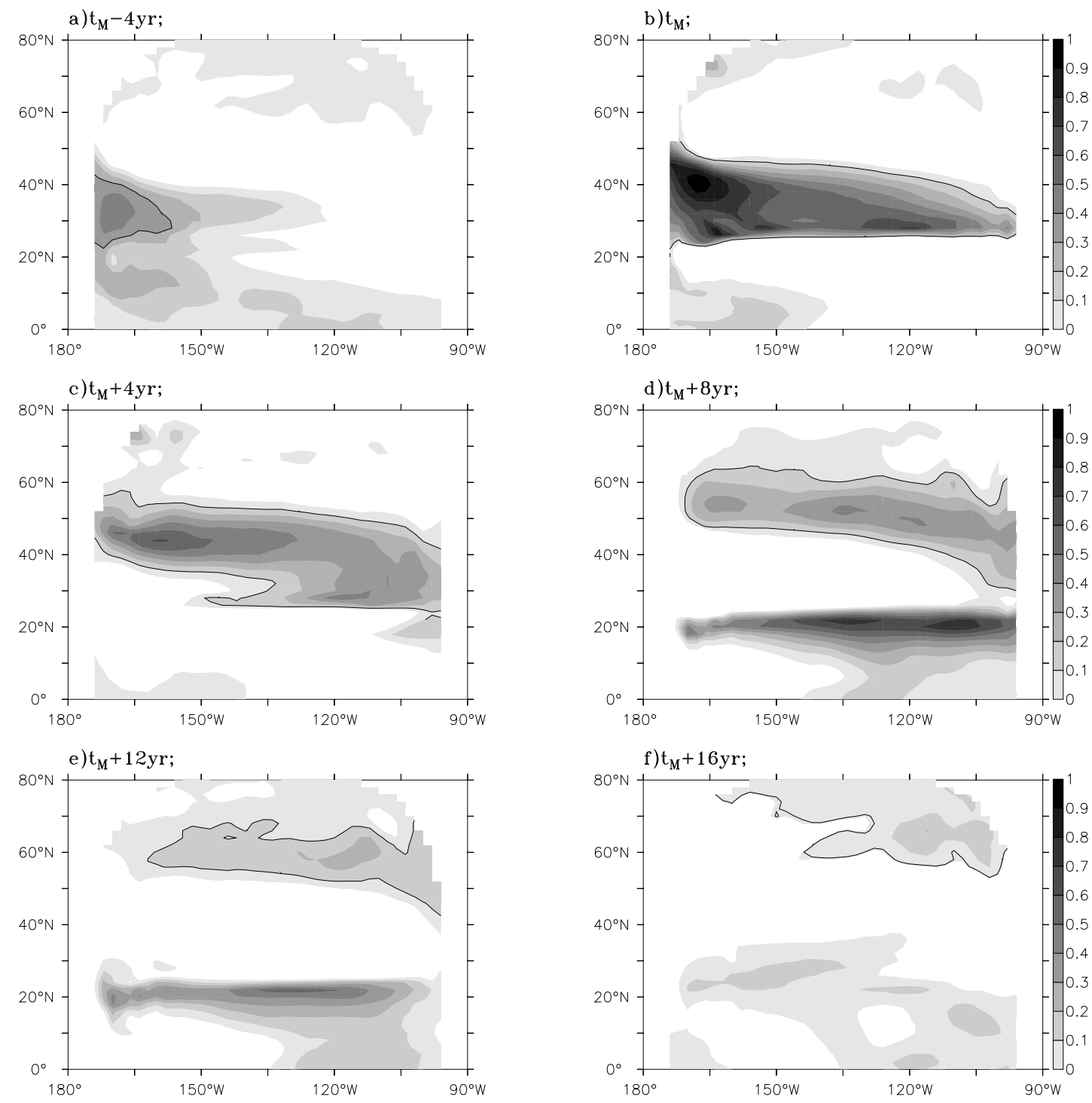

Figure 3.12: Mean SSS for $\mathrm{t}_{M}-4 \mathrm{yr}(a), \mathrm{t}_{M}(b), \mathrm{t}_{M}+4 \mathrm{yr}(c), \mathrm{t}_{M}+8(d), \mathrm{t}_{M}+12(e)$ and $\mathrm{t}_{M}+16(f)$. The $\mathrm{t}_{M}$ represent all instants when the zonally averaged SSA at $30^{\circ}$ reaches a local maxima. The black contour elucidates the anomaly propagation path. Units in $10^{-1} \times$ Psu.

This pattern of propagation is strikingly similar to the steps described by Vellinga and $\mathrm{Wu}(2004)$, but with a very different time scale. In our experiments, these anomalies are advected by the actual currents, so it usually takes less than two decades to form and reach the deep convection areas, while it takes many decades on the experiment conduced by Vellinga and $\mathrm{Wu}(2004)$. However, in both cases the anomalies originate away from the deep water formation areas and are transported until there.

On the DDrake these SSA are formed next to the western boundary between $180^{\circ} \mathrm{W}$ - 
$165^{\circ} \mathrm{W}$ and $20^{\circ} \mathrm{N}-45^{\circ} \mathrm{N}$ (defined as A3), approximately. When the freshwater flux and the SSS are compared over A3, a strong and negative correlation of -0.8 is found, indicating that these salinity anomalies are locally controlled by the surface forcing variability. Using the SSA area averaged over A3, a composite of the Freshwater flux (FWF) zonally averaged over the small basin is computed for strong and weak SSA events, using 1.5 times its standard deviation as a threshold (Fig. 3.13). It is found the SSA variability is associated with a meridional offset of the freshwater field, which produces intense anomalies between $30^{\circ} \mathrm{N}$ and $45^{\circ} \mathrm{N}$, approximately. The salinity anomalies captured in the hovmoller (Fig. 3.11) are also coherent with these freshwater anomalies, changing signals around $25^{\circ} \mathrm{N}$ and $50^{\circ} \mathrm{N}$.

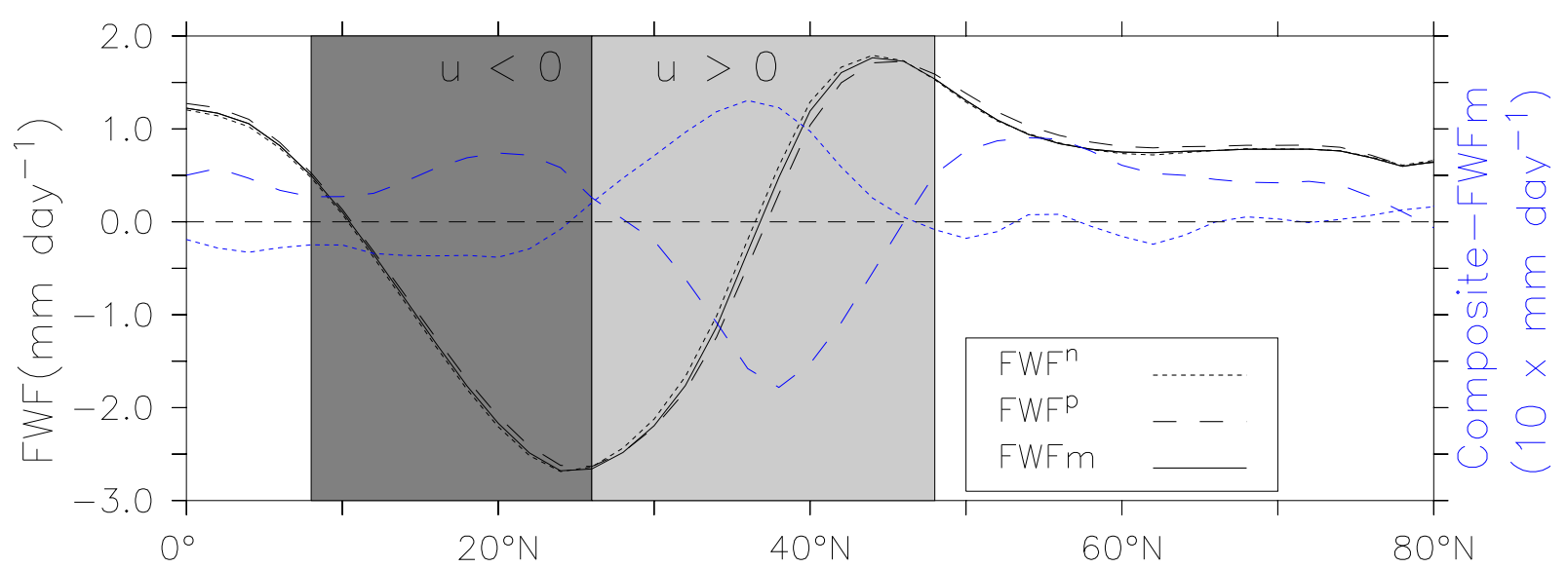

Figure 3.13: FWF zonally averaged over the small basin (FWFm, black line), and the FWF composites, composed when the surface salinity over $\mathrm{A} 3$ is greater $\left(\mathrm{FWFa}^{p}\right.$, dashed) or lesser $\left(\mathrm{FWFa}^{p}\right.$, dotted) than \pm 1.5 times its standard deviation, respectively. Units in $m m \times d a y^{-1}$. The departure $\mathrm{FWFa}^{p}-\mathrm{FWFm}$ (blue dashed line) and $\mathrm{FWFa}^{p}$-FWFm (blue dotted line) are also shown, with units in $10 \times m m \times d a y^{-1}$.

The first EOF (Fig. 3.14) of both the SSS (55\% of its variace) and freshwater flux (26\% of its variance) presents a spatial distribution coherent with the meridional shift shown by the freshwater forcing composites (Fig. 3.13). The time expansion of both EOFs presents a liner correlation of $r=-0.8$, indicating they are physically connected. When these EOFs are calculated in the northern Atlantic-like, between $50^{\circ} \mathrm{N}-85^{\circ} \mathrm{N}$ (not shown), their spatial coherence is lost in the leading EOF, reinforcing that the freshwater flux is not locally controlling the SSS in high latitudes in DDrake. 


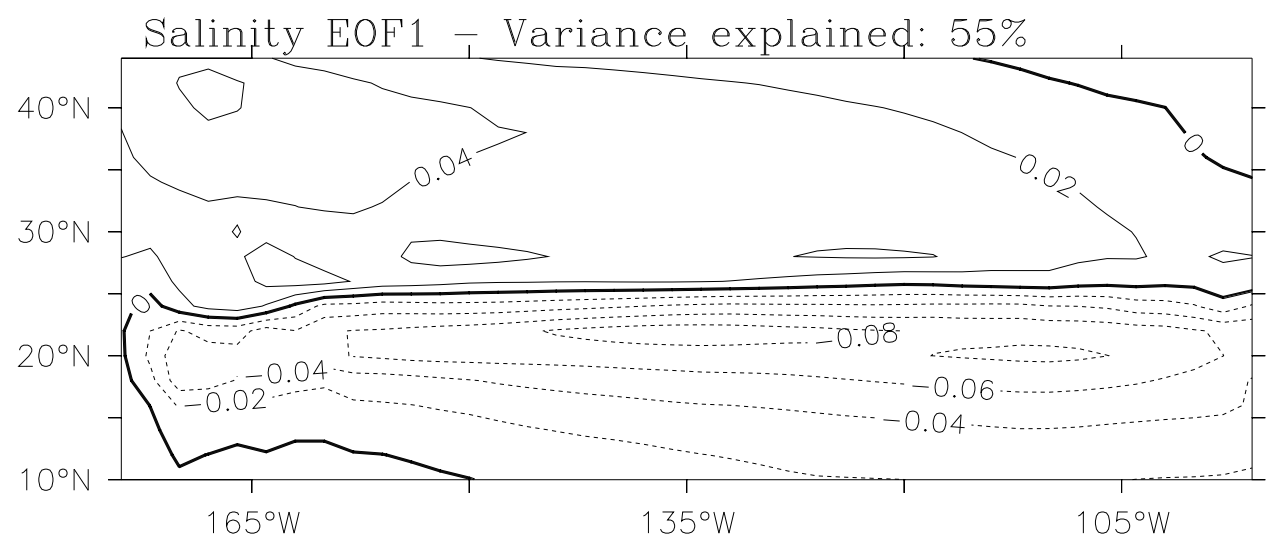

(a)

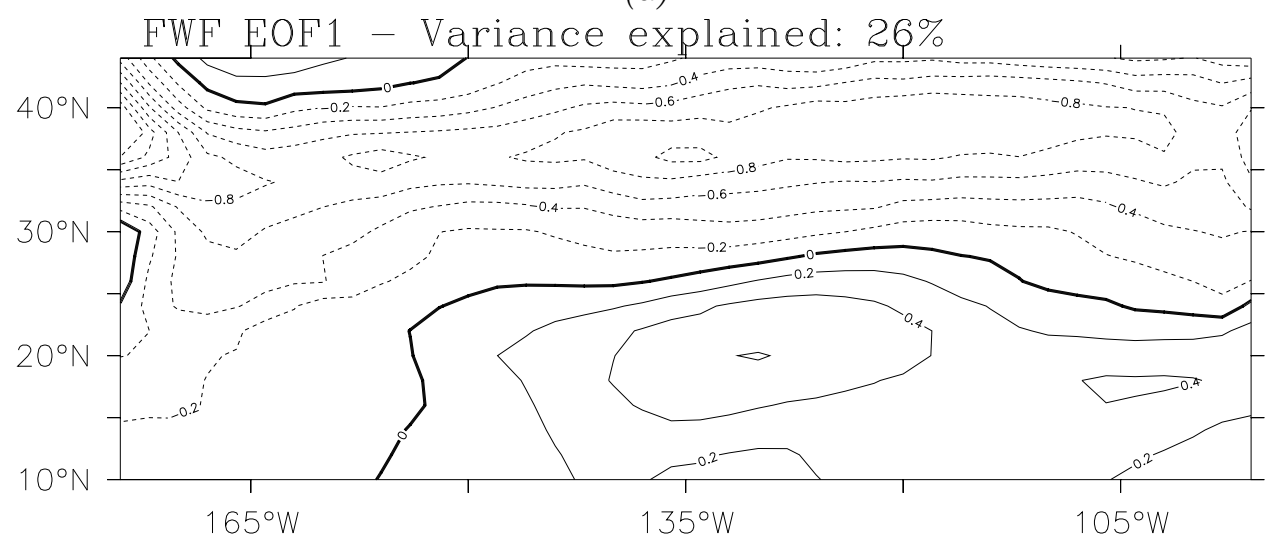

(b)

Figure 3.14: First EOF for (a) SSS and (b) freshwater flux over the small basin. Units in Psu for salinity and $m m \times d a y^{-1}$ for freshwater flux.

These results show that the SSS in the Atlantic-like is strongly associated with the meridional offset of the freshwater flux field (Fig. 3.13). The zonally averaged freshwater flux, on the other hand, directly reflects the mean atmospheric meridional circulation: in the equatorial region, the precipitation exceeds evaporation where the Hadley cell leads to convergence of moisture at low levels. On the descending branch of the Hadley and Ferrel cells, the evaporation dominates creating the dry zone in subtropics. In the extratropics, the synoptic eddies sustain the predominance of precipitation over evaporation. Hence, the meridional displacement of the freshwater flux in DDrake is suggestive to be connected to the variability of the mean atmospheric circulation, which is now explored.

\subsubsection{The Atmospheric Meridional Cells}

In order to understand the meridional offset of the freshwater flux and the atmospheric circulation, two other composites are computed for the global atmospheric meridional overturning circulation (AtMOC) regarding the strength and sign of SSA averaged over A3. 
These composites (Fig. 3.15 a) create a picture of the atmospheric meridional cells during the salinity anomalies extreme events, revealing that the meridional cells are shifted and strengthened accordingly to the salinity anomaly sign. It can be described schematically as strengthening-expansion versus weakening-shrinking of the northern Hadley cell. As the northern Hadley cell intensifies, it expands and pushes poleward the other meridional cells. When the northern Hadley cell is weak, it shrinks and pulls all others cells toward itself.

Such mechanism connects the freshwater flux and salinity anomalies to the meridional cells. It also incorporates the ITCZ positioning itself: when the northern Hadley cell shrinks, the ITCZ shifts northward while the northern downward branch of the Hadley and Ferrel cells shifts southward, moving the dry zone with it. It creates the positive freshwater flux anomaly between approximately $25^{\circ} \mathrm{N}-45^{\circ} \mathrm{N}$ (Fig. 3.13) and the ensuing negative anomaly in surface salinity. When the northern Hadley cell intensifies and expands, the opposite is observed. Thus, the variability on the AMOC captured by its EOF 3 (Fig. 3.9) is in fact connected with this pattern of atmospheric variability.

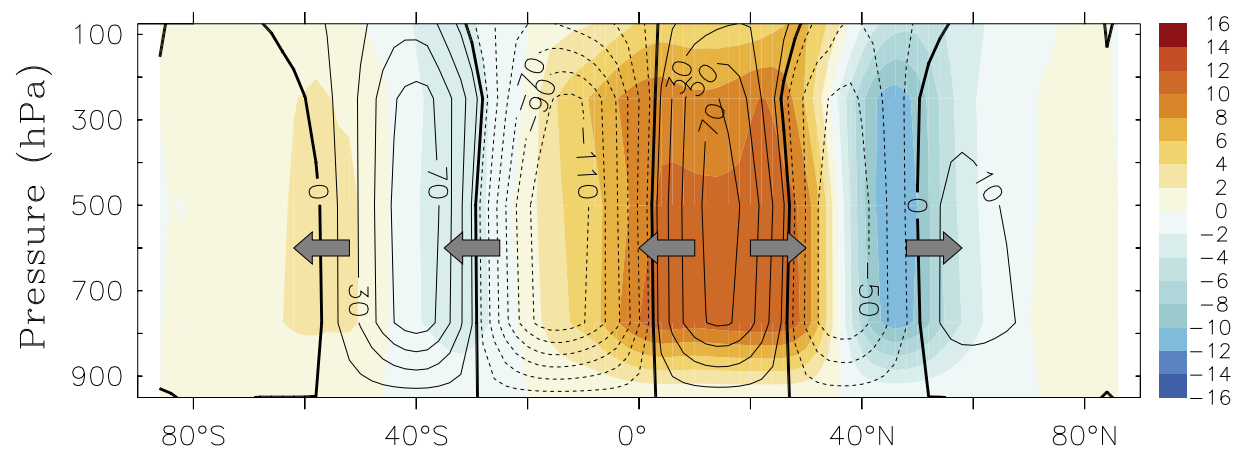

(a) Composite of the AtMOC

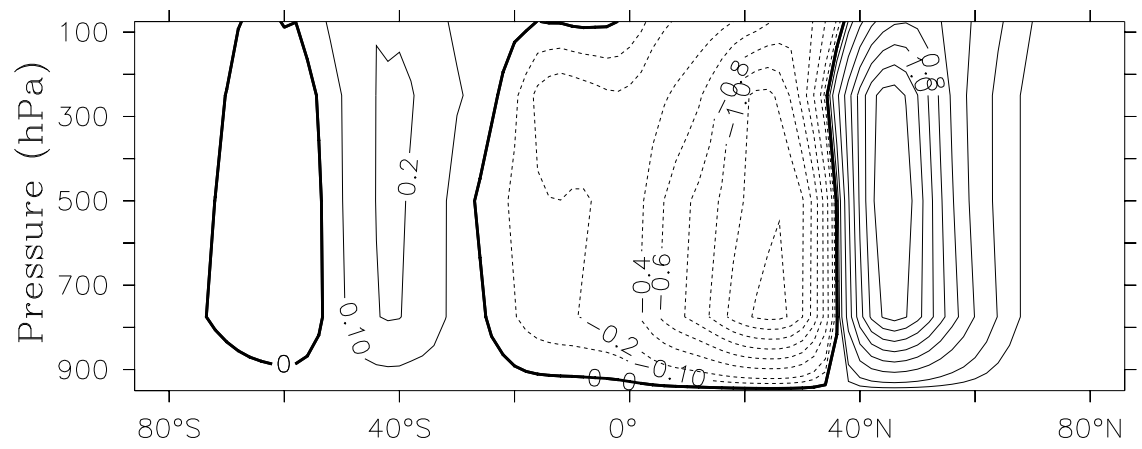

(b) AtMOC EOF 2. Variance explained: $29 \%$

Figure 3.15: The composites of the AtMOC stream function (a), composed as the SSA over A3 exceeds \pm 1.5 times its standard deviation. The colored background shows the difference of the Strong minus Weak Composites. The contouring shows the mean AtMOC stream function. The arrows denote the offset of the meridional cells between the composites. In (b) the EOF 2 of the AtMOC, explaining $29 \%$ of its variance. Units in Sv. 
The EOF 2 of the global AtMOC (Fig. 3.15b) is spatially coherent with the anomalies shown by the composites, and explains $29 \%$ of the global AtMOC variance. The leading EOF (not shown) is qualitatively symmetric to the EOF 2, with stronger variability in the southern hemisphere and explaining $59 \%$ of the total AtMOC variance. When the EOF is calculated only in the northern hemisphere, the spatial pattern of the composite becomes the leading EOF and explains $86 \%$ of the northern hemisphere variability.

The expansion coefficients of the global AtMOC EOF 2 and the freshwater flux anomalies over A3 has a linear correlation of 0.8. Additionally, using a time-lag of about 12-16 years, the correlation between the AtMOC EOF 2 and the sinking over A2 is about 0.5. The ITCZ mean position is also associated with the AtMOC EOF 2, presenting a linear correlation of about 0.64. These results indicate a strong connection of the AMOC variability with the AtMOC variability in DDrake.

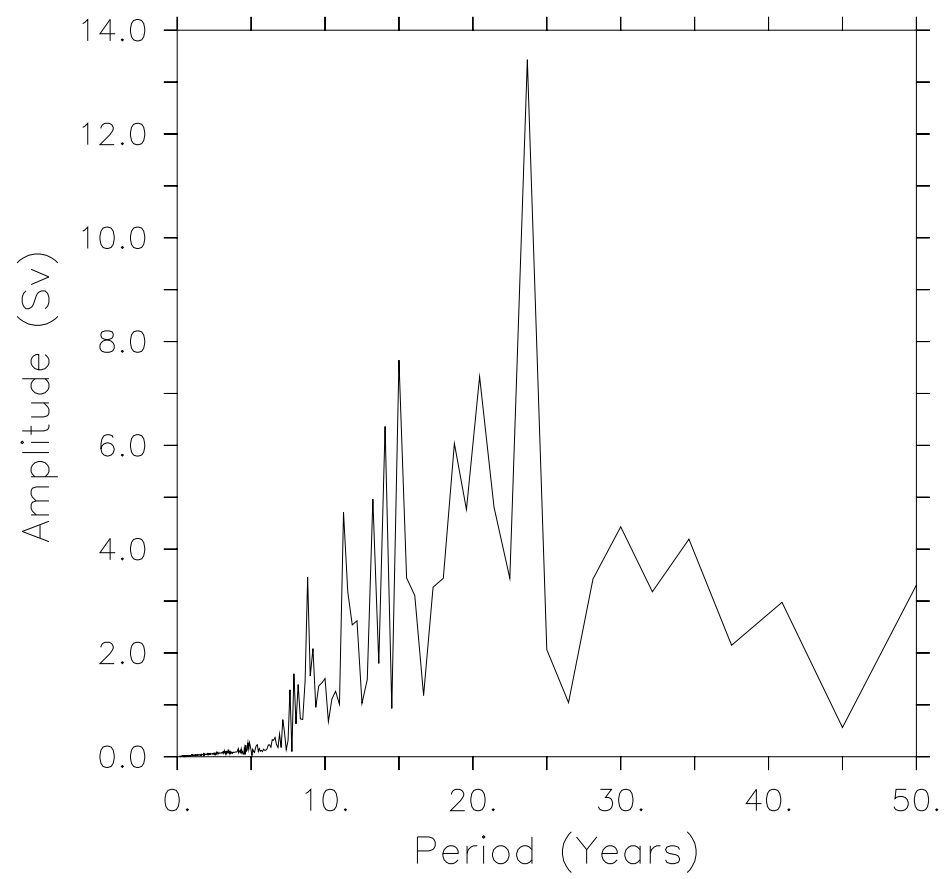

Figure 3.16: Spectra of the EOF 2 expansion coefficients for the atmospheric MOC.

The mode of variability captured by the AtMOC EOF 2 (Fig. 3.15b) is the equivalent of the zonal Index described by Oliver (2005), which is characterized by fluctuations in strength and position of the westerlies due to anomalous meridional circulation driven by eddy momentum fluxes. This meridional shift of the jets is a common component of the southern hemisphere variability (Robinson, 1991; Watterson, 2000). In the DDrake, the 
influence of the continents is critically reduced, and the zonal Index easily develops in the northern hemisphere. The leading EOF of the global AtMOC (not shown) is the zonal Index equivalent to the southern hemisphere. Marshall et al. (2007) have identified this variability in the Aquaplanet as the first mode of variability for its zonally averaged fields. They show this atmospheric mode to presets a large spectrum of variability. However, resonance with ocean circulation concentrates the power spectrum in specific frequencies. The resonance mechanism in the ocean involves heat anomalies produced by Ekman pumping in response to the anomalous wind stress, which are meridionally advected by the overturning circulation. The ocean thus rearranges the heat anomalies accordingly to its own characteristic advective timescale. After such interval, the advected heat anomalies are positioned in order to reinforce a new phase of the atmospheric variability. For the characteristic THC of Aquaplanet, this mechanism reinforces the atmospheric variability at every $\sim 10$ years (Marshall et al. 2007).

In DDrake, the MOC is different in each basin (Fig. 3.3), and both are different from the results in Aquaplanet (Fig. 3.1 a, bottom). Thus, the resonance periods may also be different in DDrake, as the adjective timescale depends on the THC. Fig. 3.16 shows the power spectrum of the expanded coefficients of the AtMOC EOF 2. Energetic variabilities are found around periods of 24,20 and 15 years.

In order to investigate the feedback mechanism between ocean and the atmospheric variability, a new composite regarding the surface salinity anomaly over A3 is computed, but for the zonally averaged temperature anomalies in Pacific-like (Fig. 3.17 a) and Atlantic-like (Fig. 3.17 b) basin, for the 0-900 m depth. One should note that, to cover both phases of the composites, for the Pacific-like the negative phase is shown, while the positive phase is shown for the Atlantic-like. At $t_{M}$, the anomalous Ekman pumping drives temperature anomalies that reaches $900 \mathrm{~m}$ depth around $30-40^{\circ} \mathrm{N}$ in both basins. In the Pacific-like, as time passes, the MOC advects and splits this heat anomaly in two different pathways: one toward the surface (green arrows) and another toward the equator in subsurface (purple arrows). The heat anomaly advected poleward splits at the surface, contributing to hold the original surface anomaly between $30-40^{\circ} \mathrm{N}$ while also contributing to shift the surface anomaly around $50^{\circ} \mathrm{N}$ (see the green arrows at $t_{M}+6$ and $t_{M}+7$ in Fig. $3.17 a$ ). The anomaly advected in subsurface takes longer to reach back the surface, what occurs at about $t_{M}+12$. This is the half cycle of the most intense peak on the EOF 
2 spectrum (Fig. 3.16), while the reinforcement at about $t_{M}+7$ coincides with the peak at 15 years per cycle. This suggest that, as each event may vary from this average description, the atmospheric variability spectrum is controlled by the arrangement between these reinforcement pathways.

The Atlantic-like is also investigated. Its meridional overturning is dominated by a strong meridional cell, different from the Pacific-like (Fig. 3.3). Their anomalies are more efficiently advected until the northern Atlantic-like (Fig. 3.17 b), tilting with height as the transport is faster at surface. Between $t_{M}$ and $t_{M}+10$, the heat (and salinity) anomaly from $30-40^{\circ} \mathrm{N}$ reaches $50-60^{\circ} \mathrm{N}$, reinforcing a new phase of the variability at a 20 years per cycle. This reinforcement, however, already began at $t_{M}+7$ and extends until $t_{M}+12$. It suggest that, depending on the AMOC strength, one or another frequency may be intensified.

Combining the Pacific-like and Atlantic-like resonance mechanisms, the colored spectrum of the AtMOC (Fig. 3.16) is mostly explained, with variance peaking at about 24, 15 and 20 years per cycle, respectively. The Pacific-like, with its shallow meridional cells reminiscent from the Aquaplanet, presents a more complex feedback mechanism to the atmospheric variability. In the Atlantic-Like, on the other hand, the heat anomalies are advected poleward, and although they interact with the atmosphere at surface, most of the heat and salty anomalies are injected into the deep ocean by the AMOC. In fact, these anomalies introduced in the deep ocean by the AMOC are those tracked through this section. 
a) Temp. and MOC (Pacific-like)

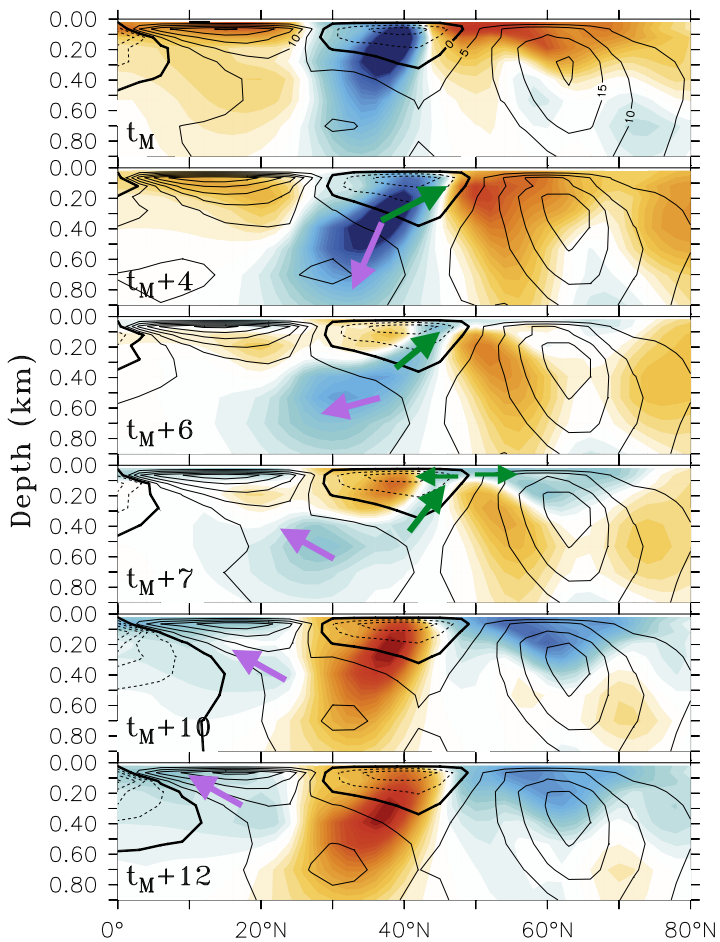

b) Temp. and Sal. (Atlantic-like)

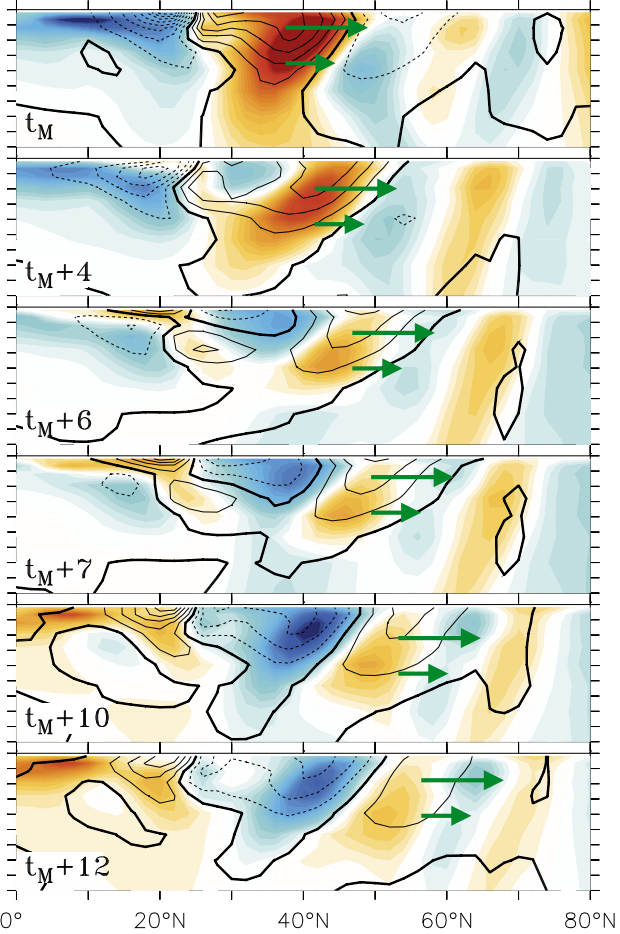

Figure 3.17: Composites of the heat $(\mathrm{a}, \mathrm{b})$ and salinity $(\mathrm{b})$ anomalies, associated to the zonal Index variability. The contour in (a) shows the composite of the THC, while the contours in (b) shows the salinity anomalies. Units are in ${ }^{\circ} \mathrm{C}$, Psu and Sv.

Although these results are related to the equivalent of the zonal Index in DDrake, changes on the meridional cells in the atmosphere are observed at other occasions. Investigating atmospheric reanalysis products, Seager et al. (2003) show that during El-Niño events meridionally and zonally symmetric anomalies are formed, with an intensified and contracted Hadley circulation. Among the simulations from the Fourth Assessment Report of the Intergovernmental Panel on Climate Change, as a response to global warming, it is found a weakening and a poleward expansion of the Hadley circulation (Lu et al. 2007). It is also found a poleward shift of the eddy-driven jets and midlatitudes storm tracks. In Vellinga and $\mathrm{Wu}(2004)$ there are changes in the Hadley cell and ITCZ mean position related to the MOC intensity. The asymmetry of the Hadley cell and the ITCZ positioning is associated with the interhemispheric temperature gradient in timescales from glacial-interglacial to decades, which is influenced by the OHT, radiation, clouds, aerosols and surface processes at all latitudes (Bischoff and Schneider, 2015; Broccoli et al., 2006; Kang et al., 2008; Yoshimori and Broccoli, 2008; Zhang and Delworth, 2005). In the DDrake, the meridional excursion of the great atmospheric cells presents itself capable to introduce anomalies into 
the ocean thermohaline circulation. It is reasonable to suggest that similar variations in the real world, as mentioned, would print their signature in the SSS. However, whether these salinity anomalies would reach and impact the deep convection or being erased by surface forcing is an interesting question, but out of the scope of this study.

\subsubsection{Meridional Heat Transport}

The previous sections described the mechanism in the DDrake that connects the meridional cells of both atmosphere and ocean circulation. The atmospheric component incorporates the ITCZ itself, while the oceanic component involves variabilities in the AMOC. As the ITCZ position and the MOC are attributed to be the major controllers of the AHT and the OHT across the equator (Marshall et al. 2014), respectively, it is raised the question whether such mechanism would also connects the ATH and OHT.

Fig. 3.18 shows the linear regression for AHT vs ITCZ position and OHT vs AMOC. There is a strong correlation of 0.9 for the OHT vs AMOC, suggesting the anomalies in the AMOC identified earlier contribute significantly to the OHT variability. In fact, the OHT and the AMOC EOF 3 (Fig. 3.9 c) present a correlation of approximately 0.4. Hence, according to the mechanism described earlier, the strengthening and expansion of the northern Hadley cell leads to a positive anomaly in the SSS, which in turns is advected to northern latitudes and impacts on the AMOC intensity and affecting the OHT across the equator.
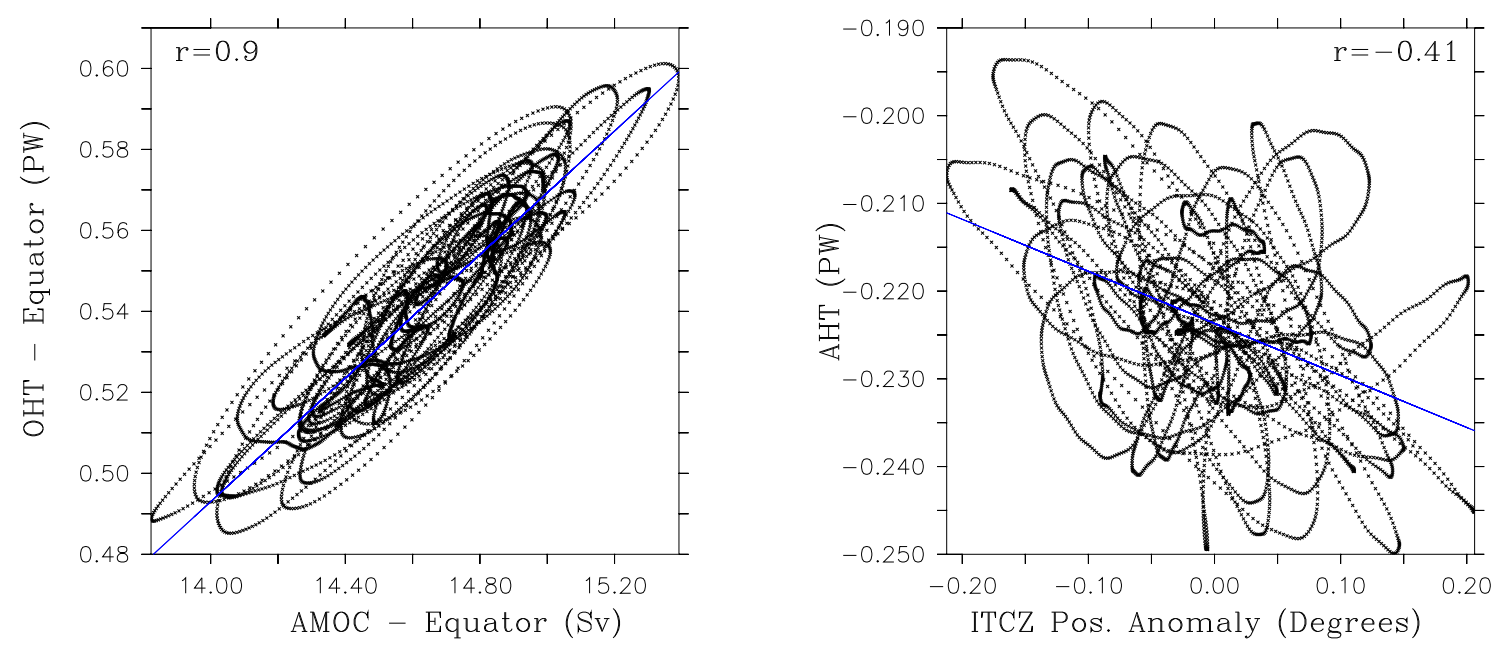

Figure 3.18: Dispersion plot for OHT and MOC (a) and AHT and ITCZp (b). The blue lines are the best fit of a linear regression, and the $r$ denotes the linear correlation coefficient. 
With regard to the atmospheric component, the correlation between AHT and the ITCZ position is about -0.4, weaker than the oceanic component. Since the Hadley Cell can change its strength without a meridional shift, the AHT can vary without changing the ITCZ position. Hence, the meridional component of the wind at the surface, zonally averaged over the equator, is used as a proxy of the Hadley cell strength and position altogether (referred to as ITCZp). The AHT and the ITCZp presents a correlation of -0.7.

Comparing the expansion coefficients of the global AtMOC EOF 2 to the ITCZp, it gives a correlation of 0.5 , while when the EOF 2 is compared to the ATH a correlation $<|0.1|$ is found. Additionally, the AtMOC EOF 1 is also compared to ITCZp and AHT, with very similar results. It shows that, although the zonal Index equivalent in DDrake affects the tropical circulation, the inter-hemispheric AHT is insensitive, and there is no direct compensation between OHT variability and AHT.

It is found however that the AMOC variability impacts the interhemispheric OHT, with possible later impact on the AHT, depending on whether or how these heat anomalies reach the surface and affect the interhemispheric thermal gradient (Broccoli et al., 2006; Kang et al. 2008). Kang et al. (2008) show that the ITCZ position responds to the imposed cross-equatorial heat flux in the ocean and this response is treated as the compensation of the AHT from the imposed OHT. It is then reasonable to expect that the OHT anomalies investigated here may later impact the Hadley cell and the AHT, as the anomalies in the deep ocean from the northern Atlantic-like would return to surface and feedback into the atmosphere. When the AtMOC is computed between $20^{\circ} \mathrm{S}$ and $20^{\circ} \mathrm{N}$ (not shown), its EOF 3 strongly correlates to the AHT across the equator, accounting for about $45 \%$ of the AHT variability. This indicates that, despite the mechanism described here does not directly impact the AHT, the variability in the meridional cells does account significantly for the AHT variance, and these variabilities can still be the subject of the OHT anomalies influence. However, the required investigation to answer these questions is out of the scope for this study.

\subsubsection{Remarks on DDrake's Variability}

The variability in the results of the idealized DDrake experiment has been analyzed to investigate and describe a mechanism that links an atmospheric pattern of variability and the AMOC, on inter-decadal timescale. The anomalies found in the deep ocean circulation 
were tracked back to the atmospheric forcing, which is a pattern of atmospheric variability that comprehends its main meridional cells, an equivalent of the so-called "zonal Index". In DDrake, it presents itself as a mechanism of strengthening-expansion vs weakeningcontraction of the northern Hadley cell.

In the Atlantic-like basin, the latitudinal shift of the atmospheric cells leads to freshwater anomalies that change the SSS over the subtropics. These salinity anomalies are advected northward by the mean ocean circulation until the areas of deep convection. As the salinity anomalies reach the deep convection areas, they impact the downwelling and the AMOC strength, affecting also the interhemispheric OHT.

The meridional shift of the atmospheric cells leads to heat anomalies due to anomalous Ekman pumping in both Atlantic-like and Pacific-like basins. In the Atlantic-like, these heat anomalies are advected with the described salinity anomalies and are introduced into the deep ocean by the mean THC. In the Pacific-like, the circulation has meridional cells reminiscent from the Aquaplanet, which recirculates the heat anomalies to the surface. In both basins, the paths of the heat anomalies lead to a resonance with the atmosphere, modulating the spectrum of the zonal Index variability.

The physical mechanism described in the present study prints its signature on the most significant EOFs of the ocean and atmospheric overturning circulations. The meridional shift of the atmospheric cells is coherent with the EOF 1 of the AtMOC computed in the northern hemisphere, explaining about $86 \%$ of its variance. As described, the anomaly signal propagates northward where it goes into the deep ocean, printing itself on the EOF 3 of the AMOC and explaining about $15 \%$ of its variance. Thus it involves most of the coupled system variability on interdecadal timescale for the DDrake experiment.

Regarding the meridional heat transport partition, the ITCZ position and the AMOC have different contributions to the AHT and OHT, respectively. It is found the ocean to readily affect the interhemispheric OHT through the AMOC, and the pattern of variability we have focused on accounts for $15 \%$ of the OHT variability, showing itself efficient to introduce anomalies in the interhemispheric energy balance. The atmospheric component, however, shows little impact on the AHT across the equator, as it concentrates most of its energy on the extratropics.

The mechanism described here starts from the atmospheric variability to the deep ocean, impacting the interhemispheric OHT. It is still possible, however, these OHT ano- 
malies to impact later the Hadley cell and the AHT. It depends on how or whether these anomalies return to the surface and affect the interhemispheric thermal gradient.

The results from DDrake thus suggest that, despite its idealized topography, it has proved itself to be capable of reproducing important features of the mean climate system, as well as giving new insights on the ocean and atmospheric coupling mechanism.

\subsection{Intermediate Experiments}

After investigating the DDrake's climate, the increasing in topography's complexity continues. Several attempts were made, most of them leading to a dead end. However, at each step the topography was improved and perfected. Some of these experiments and its results are briefly summarized here.

\subsubsection{DDrake Extended}

The DDrake explored in section 3.2 has one important characteristic: both the meridional barriers end at the same latitude. Thus, before attempting to introduce a new land barrier and investigate the Throughflow, it was investigated the impact of a mismatch in the latitudinal termination of the land barriers. It was learned from this experiment that the mismatch between the western and eastern boundaries changes the heat and salt transport into the northern basins. Specifically, the extended American-like continent increases the equivalent of the "cold route" (Gordon, 1986), introducing a positive buoyancy anomaly in the Atlantic-like basin. The AMOC weakens, the interhemispheric OHT and AHT reduces and the ITCZ shifts equatorward. The "warm route", on the other hand, is blocked by the insufficient gap between the African-like tip and the maximum Southern Hemisphere westerlies at surface, leading to a viscous choking and a complete retroflection of the Agulhas Current (Dijkstra and de Ruijter, 2001) .

The problem this experiment has pointed out is the need to correctly set the meridional barrier termination regarding the wind field, in order to better reproduce the Ekman transport at each basin entrance. Moreover, the extended American-like continent has blocked the ACC-like under the Southern Hemisphere westerlies, which remains close to $40^{\circ} \mathrm{S}$. The meridional extent of the atmospheric meridional cells has changed from Aquaplanet to the DDrake, in response to the meridional barriers. However, in all idealized experiments 
explored in this study, the meridional extension of the atmospheric meridional cells remain different from observation. Thus, this suggest the meridional extent of the meridional barriers must consider the wind field from the idealized experiment.

\subsubsection{Triple Drake First Version}

These experiments are the first attempt to introduce an IT-like on the idealized experiments. A third meridional barrier was introduced on the DDrake-Extended, configuring three northern basins, whereby the idealized continents ends at similar latitudes of America, Africa and Australia, respectively. Additionally, a two-grid wide passage is opened at $10^{\circ} \mathrm{S}$ on the third meridional barrier, acting as the IT. Hence, there are two experiments: NoITF, where the passage is closed; ITF, with the passage open. Many comparisons between these two experiments were performed, with some striking similarity to the observed impact of the IT on climate. However, this experiment is quite problematic, as the overall THC changes dramatically. Specifically, the intermediate basin, which would play the role of the Indian ocean, directly competes with the Atlantic-like basin in the deepwater formation and to host the most intense meridional overturning. Despite this problem, one interesting result is the compensation between the Indian-like and the Atlantic-like basins in terms of their OHT. The increased THC in the Indian-like is followed by a weakening on the Atlantic-like THC, which is followed by the OHT in each basin. The net result is a global OHT very close to the DDrake, despite all differences in ocean circulation. Moreover, the overall climate of this Triple Drake first version is closer to the DDrake than the DDrake-Extended.

\subsection{The Triple Drake Experiment}

After a series of attempts, an idealized topography was finally proposed to investigate the throughflow. The earlier experiment, DDex, has pointed out that the land barriers termination must consider the wind field that correctly represents the Ekman transport at the entrance of each basin. Fig. $3.19 a$ shows the mean-zonally averaged surface wind from NCEP, indicating the southern tip of Africa, Australia and the Drake Passage. Considering the relative position of these topography features to the wind field, the termination of each barrier in TD00 is chosen as shown in Fig. $3.19 b$. 


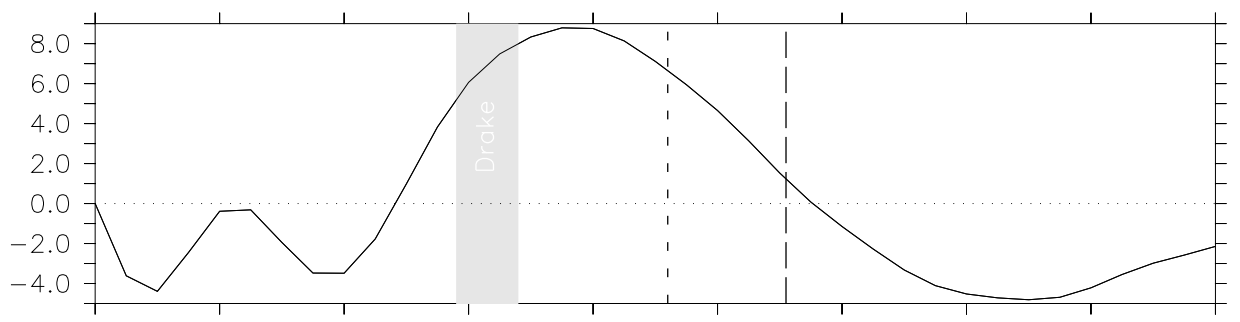

(a) NCEP

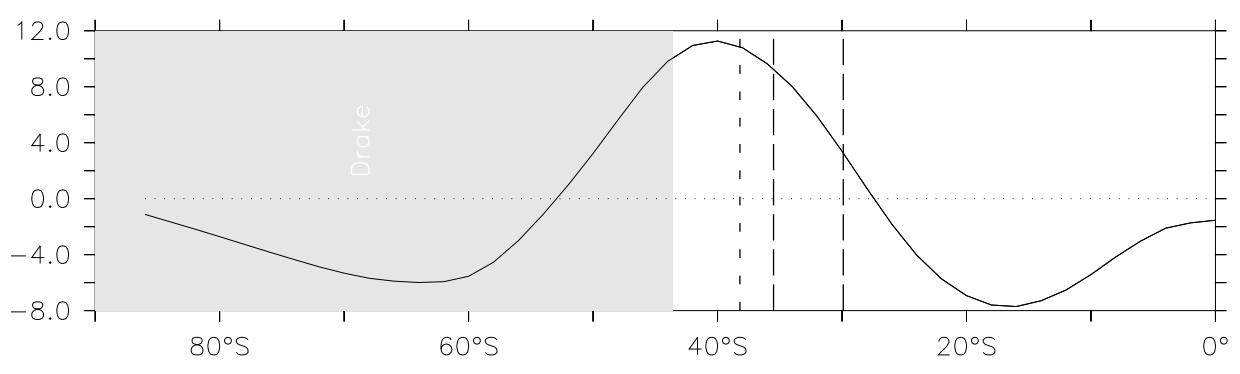

(b) TDrake

Figure 3.19: Time mean and zonally averaged wind at surface, for 10 years averaged from NCEP (a). On (b) the time mean and zonally averaged zonal wind for DDrake. The gray background denotes the Drake passage. The long dashed lines denotes the termination of the second land barrier or the African continent, and the short dashed lines the termination of the third land barrier or the Australia. On (b) there is two long dash lines, one for TD00 and TD01 and the other for TD10 and TD11. Units in $m \times s^{-1}$.

In the Aquaplanet experiment, the meridional cells of the atmospheric circulation have different extensions than observations. The Polar cell reaches approximately $53^{\circ} \mathrm{S}$ while the maximum westerlies lies around $40^{\circ} \mathrm{S}$ (Fig. 3.19b). Hence the southernmost land barrier (the American-like continent) must end between those latitudes, but closer to $40^{\circ} \mathrm{S}$. Similarly, the termination of the second and third barriers are set between the maximum westerlies and the northernmost position of the Ferrel cell (near $28^{\circ} \mathrm{S}$ ), keeping the second barrier shorter than the third one. These changes improves the dynamical background in TD00. 
a)

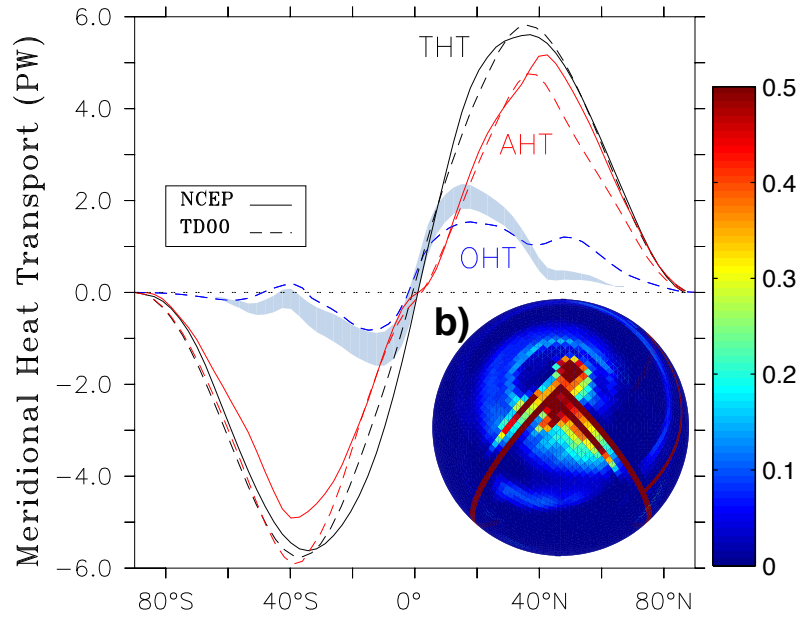

c)

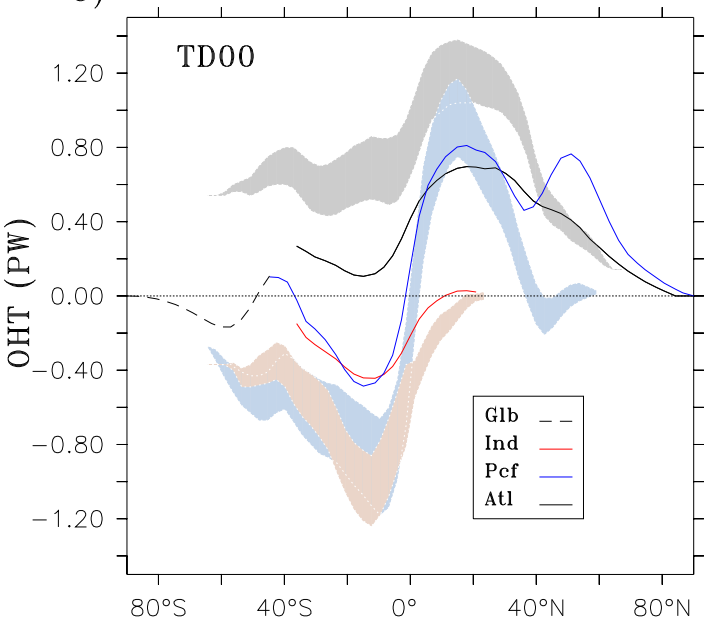

Figure 3.20: On (a) the total heat transport (THT; black), the atmospheric heat transport (AHT red) and the ocean heat transport (OHT; blue) for the DDrake (dashed lines) and the best estimation from Trenberth and Caron (2001) (solid lines and background fill), for the reanalysis from the NCEP. The range on the OHT from NCEP (blue background) represents the uncertainties on the authors estimations. Units in PW. In (b) the fraction of time the convective adjustment is active on each grid cell, averaged over the top $700 \mathrm{~m}$. In (c) the partition of the OHT between the Atlantic-like (black; line), Pacific-like (blue; line) and Indian-like (red; line) basins, compared to correspondents transports from Trenberth and Caron (2001) for the NCEP reanalysis (colored background). From $90^{\circ} \mathrm{S}$ and $45^{\circ} \mathrm{S}$, the THT of the DDrake is shown (dashed black lines), since the basins are laterally unblocked on the southern latitudes.

\subsubsection{The TD00 Mean State}

To allow the extrapolation of the following results to the Earth's climate, considering the hypothetical scenario for ice ages described in section 1.6, and also considering the high idealization in topography employed here, it is expected the TD00 to reproduce a THC in which the Pacific competes with the Atlantic Ocean in the deepwater formation. Moreover, the deep convection has to be present in both the northern Pacific and northern Atlantic, which is confirmed by the convective Index averaged on the top $700 \mathrm{~m}$ (Fig. 3.20 $b)$.

The total meridional heat transport of TD00 is similar to the modern climate estimative from Trenberth and Caron (2001) (Fig. 3.20 a). The OHT in glacial periods is expected to be similar to the present climate as well (Miller and Russell, 1989, Webb et al., 1997), but with decreased OHT on northern latitudes and increased maximum OHT in the North Pacific.

Fig. 3.20 c compares the OHT partition between each basin of TD00 and the transports from Trenberth and Caron (2001). In the Atlantic-like basin, the OHT is predominantly positive over all latitudes, leading to an interhemispheric OHT of about $0.4 \mathrm{PW}$, in ac- 
cordance to a similar aquaplanet experiment (0.4 PW; Marshall et al., 2014) and more direct inferences of the Atlantic Ocean $(0.4 \pm 0.1 \mathrm{PW}$; Ganachaud and Wunsch, 2000). The OHT in the Pacific-like is mostly poleward, but with an interhemispheric OHT of about $0.2 \mathrm{PW}$, while in the Indian-like the OHT across the equator is about $-0.2 \mathrm{PW}$. The Indian-like OHT is mostly southward, as observations. In general, although the differences in magnitude, the OHT is consistently distributed among basins, with a similar interplay as observed in modern climate. There is, additionaly, an enhanced OHT in the North Pacific, as expected during ice-ages (Miller and Russell, 1989, Webb et al., 1997).

The interhemispheric OHT in the Pacific-like is half of the OHT in the Atlantic-like basin. This reflects the strengthening of the THC in the Pacific-like (Fig. $3.23 b$ ), which evolves toward a weak and shallow version of the THC on the Atlantic-like (Fig. $3.23 a$ ). Considering the differences in topography between these idealized experiments and those from Sijp and England (2009), the overall THC obtained here is the equivalent of their THC after a $6^{\circ}$ equatorward shift of the southern hemisphere westerlies. Additionally, the THC of TD00 is coherent with the enhanced THC in the Pacific when the NADW formation is weak, inferred from paleorecords (Duplessy et al., 1988; Keigwin, 1998). These results thus suggest that the TD00 is a dynamically equivalent of the alternative climate hypothesized for an ice-age scenario (section 1.6), and such equivalence is further used to extrapolate the throughflow's impact on the TD00 onto the ice-age climate as well. 


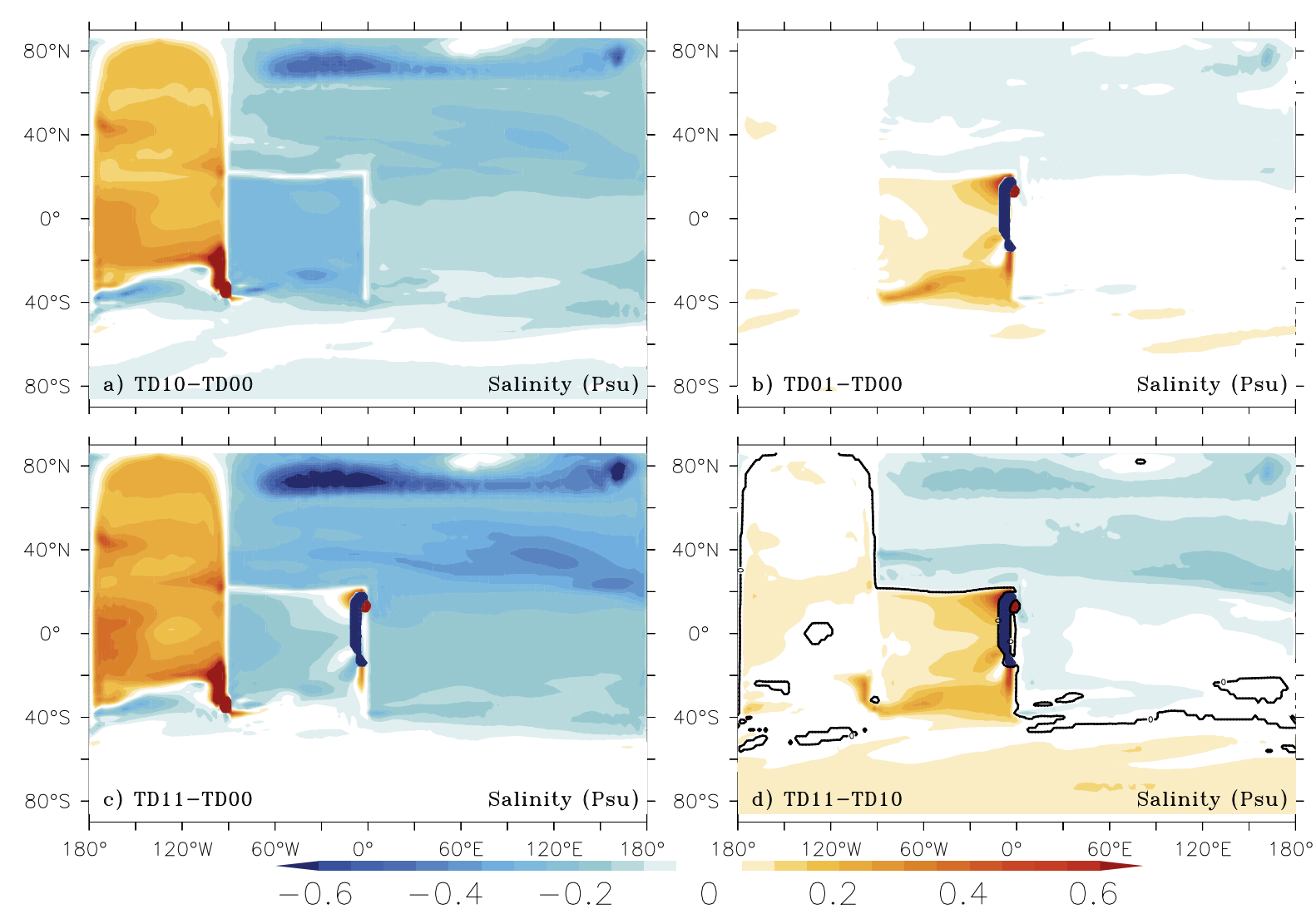

Figure 3.21: The departures of the SSS for TD10-TD00 (a), TD01-TD00 (b), TD11-TD00 (c) and TD11-TD10 (d). Units in Psu.

\subsubsection{The Agulhas Leakage effect}

The impacts of the IT are explored in two situations: with and without the AL. Thus, before addressing the impacts due to the IT itself, the effect of the AL must be understood in these experiments. The AL in these coarse resolution experiments is the water transfer from the Indian-like to the Atlantic-like by only the mean flow, as eddies are not resolved but parameterized. 


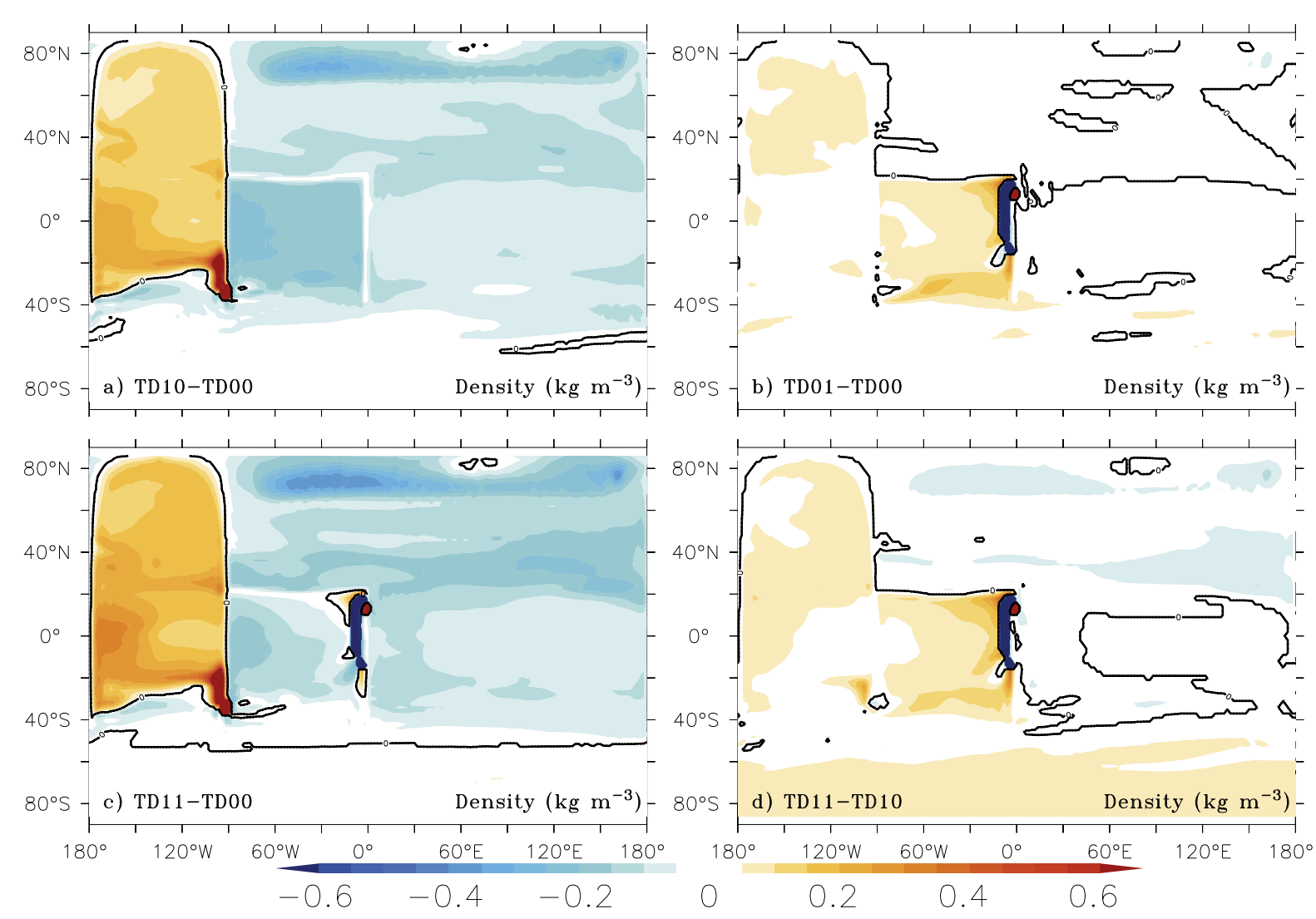

Figure 3.22: The same as Fig. 3.21 but for the surface density. Units in $\mathrm{kg} \mathrm{m}^{-3}$.

Qualitatively, the following results for the AL also applies to the TD11, but the attention is concentrated in the TD10 (the anomalies are TD10 minus TD00), for simplicity. Through its mass transport, the AL directly impacts on both Atlantic-like and Pacificlike stratification, increasing the SSS all over the Atlantic-like basin, while it is decreased everywhere else (Fig. 3.21 a). The same is found for the surface density (Fig. $3.22 a$ ). The changes in SSS and buoyancy over the Atlantic-like leads to a strengthening of the maximum AMOC streamfunction up to $2 \mathrm{~Sv}$ (Fig. $3.23 \mathrm{c}$ ), while in the Pacific-like the THC streamfunction weakens up to $3 \mathrm{~Sv}$ over the recirculation cell on $60^{\circ} \mathrm{N}$ (Fig. $3.23 d$ ). Through the changes in the THC, the individual basin contribution to the interhemispheric OHT mostly compensates each other. The OHT increases in the Atlantic-like by 0.07 PW and weakens in the Indo-Pacific-like by $-0.08 \mathrm{PW}$, leading to a change in the global OHT across the equator of about $-0.01 \mathrm{PW}$. 

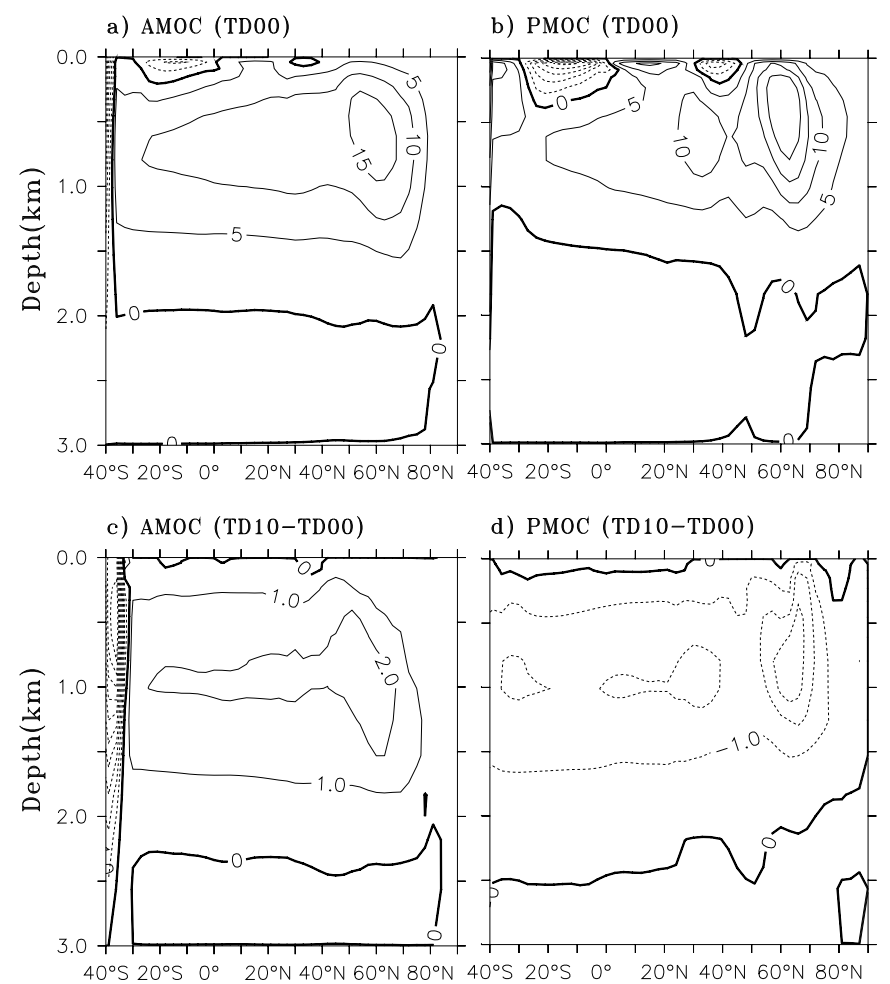

e) AMOC (TD01-TDO0) $\times 10$

f) PMOC (TD01-TD00) $\times 10$

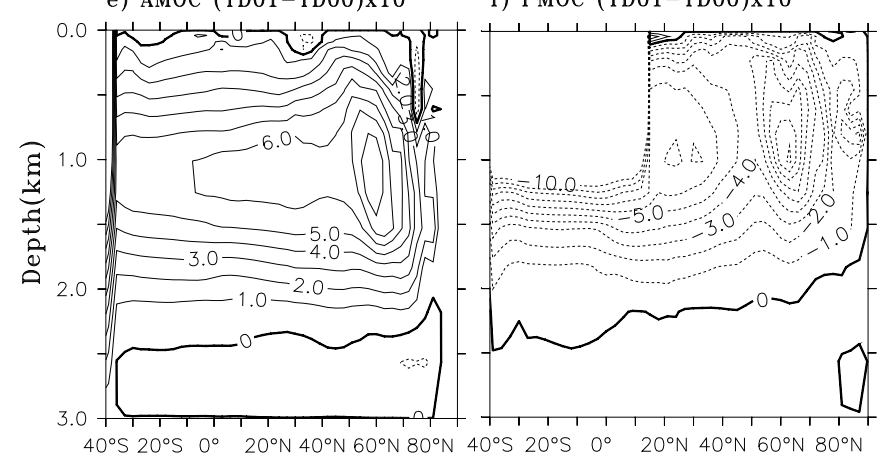

g) $\mathrm{AMOC}(\mathrm{TD} 11-\mathrm{TD} 10) \times 10$

h) PMOC (TD11-TD 10) 10

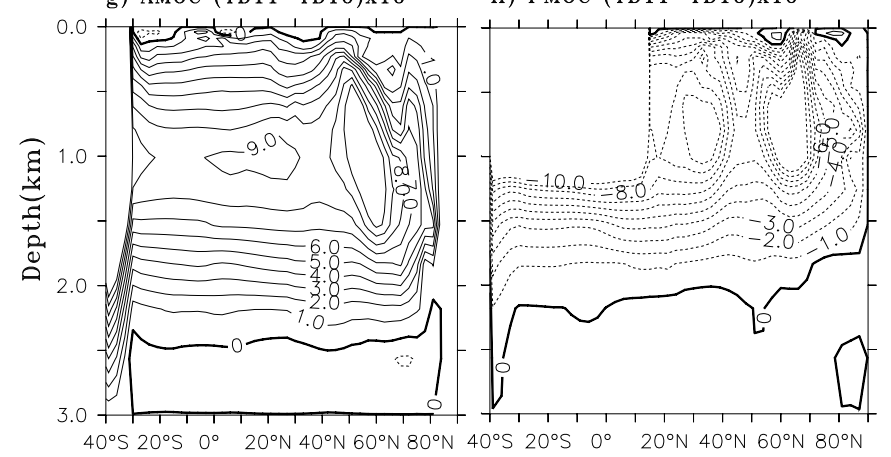

Figure 3.23: The Atlantic-Like meridional overturning stream function for the TD00 (a) and the departures TD10-TD00 (b), TD01-TD00 (c) and TD11-TD10 (d). The (b), (d), (f) and (h) are the same, but for the Pacific-like meridional overturning circulation (PMOC) stream function. Units in Sv, except in (e) to (h), where units are in $10^{-1} \times \mathrm{Sv}$.

The AL in TD10 thus presents the same seesaw effect observed from a poleward shift of the southern hemisphere westerlies (Sijp and England, 2009), except here the anomalies 
are triggered by changing the topography rather than shifting the wind forcing. Here, for TD10, the anomalies in the freshwater flux integrated over Atlantic-like and Pacificlike, between $20^{\circ} \mathrm{N}$ and $90^{\circ} \mathrm{N}$ are $-14 \mathrm{~mm} \times$ year $^{-1}$ and $2 \mathrm{~mm} \times$ year $^{-1}$, respectively. However, the zonally averaged SSA is about $\pm 0.2 \mathrm{Psu}$ in Pacific-like and Atlantic-like basins, respectively, suggesting the freshwater flux does not controls the intensity of the salinity anomalies.

Furthermore, the inter-basin seesaw mechanism acts as a positive feedback between the THC circulation and salinity, reinforcing the northern latitudes anomalies. Given an initial (say negative) anomaly in the northern Atlantic salinity, it weakens the deep convection and slows-down the THC circulation, thereby increasing the residence time of the surface waters there and giving more time to the positive freshwater forcing to operate in midhigh-latitudes. It thus reinforces the salinity anomaly and the overturning weakening. In other words, due to the differences in their THC, the Atlantic-like is less sensitive to the relatively strong and positive freshwater forcing, while the Pacific-like is more sensitive to its relatively weak and negative freshwater forcing, so the salinity anomalies are similar in both basins.

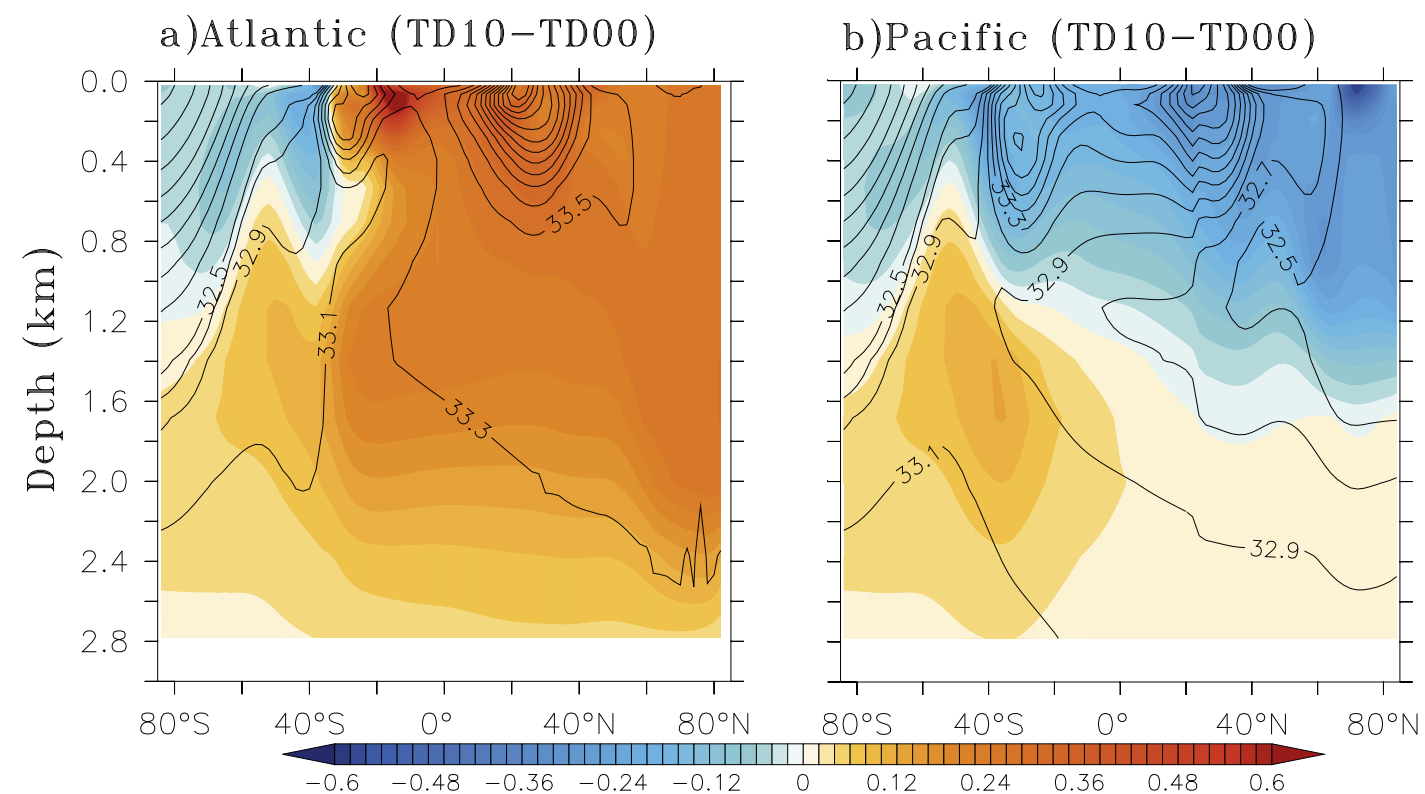

Figure 3.24: Zonally averaged salinity anomaly for the Atlantic-like (a) and Pacific-like (b) basins, for TD10 (TD10 minus TD00). Units in Psu.

For the TD10, the feedback mechanism starts with the Atlantic-like salinization through the AL transport, which decreases the northern Atlantic-like buoyancy and increases the NADW-like formation. Whether the freshwater flux anomaly is not strong enough to 
inhibit the inter-basin seesaw to acts in the Pacific-like, the saltier deepwater from Atlanticlike slowly increases the bottom salinity in the Pacific-like, increasing its stratification and inhibiting its THC. Thus, the salinity anomaly is also reinforced in the northern Pacificlike. The increased salinity in the NADW-like and bottom Pacific-like is seen in Fig. 3.24 $a$ and $b$.

In summary, the AL increases the AMOC while weakens the THC in the Pacific-like, shifting the inter-basin seesaw toward the increased NADW-like formation. This seesaw effect also prints its signature in SST (Fig. $3.25 a$ and $b$ ), leading to the antiphase variation between the North Pacific and North Atlantic SST's inferred in paleorecords (Kiefer et al., 2001).
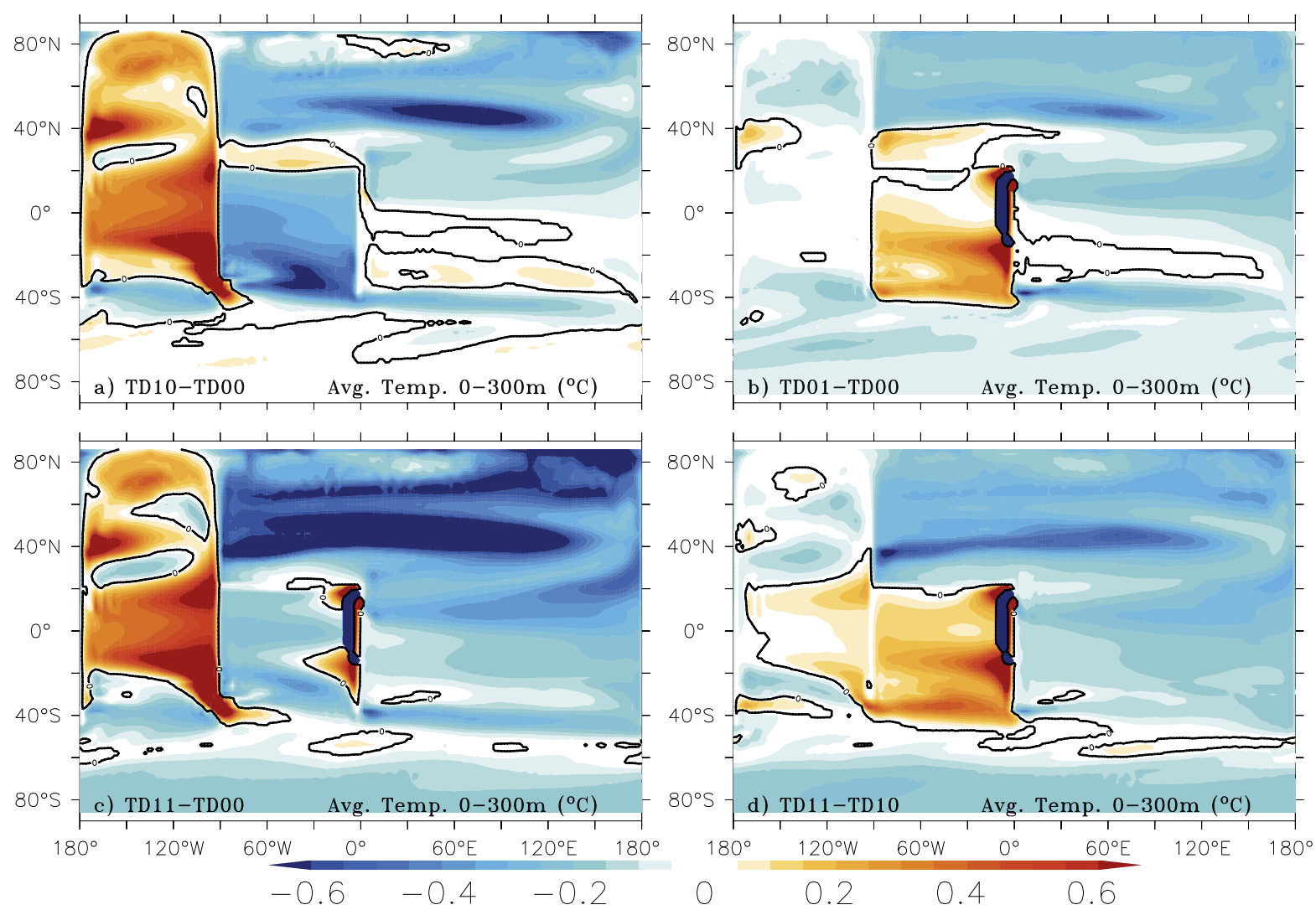

Figure 3.25: The same as Fig. 3.21 but for the temperature averaged in the upper $300 \mathrm{~m}$. Units in ${ }^{\circ} \mathrm{C}$.

\subsubsection{The Indonesian Throughflow}

Attempts to understand the IT's impact on today's climate has been extensively documented. Here its effects are investigated in a essentially different scenario, focusing on to the change in to the IT hemispheric water source. The arguments to explain the increased South Pacific water contribution to the IT in the hypothetical ice age scenario are based 
on the fact that the enhanced northern Pacific-like sinking demands thermocline waters from the south hemisphere to cross the equator, flowing through the IT's entrance and replacing the low-salinity North Pacific waters. The today's IT has about $30 \%$ of waters from the southern hemisphere (van Sebille et al., 2014), but rather than simulate a precise estimative of the hemispheric water contribution, it is sufficient to the present goals to obtain an IT only fed by the southern hemisphere waters, which is the case in the present experiments. The new water source changes the IT's impact from what is observed in the modern climate, which is here defined as the overall results from Song et al. (2007) and its references (see section 1.1).

To correctly read these results, one may have in mind that the impacts of the IT are assessed in two cases: with (TD11-TD10) and without (TD01-TD00) the AL. When both cases present similar results, they are described together with no distinctions. When appropriated, variations of this interpretation are used and the reader is advised.

The SSA in the Indian- and northern Pacific-like due to the open IT (Figs. 3.21 $b$ and $d$ ) has the same signal of those from a blocked IT on modern climate. This reversed salinity anomalies directly reflects the changes in the salinity transport, which fills the upper Indian-like basin with the saltier southern Pacific-like waters.

The upper heat budget and the SSA in the northern Pacific-like and northern Atlanticlike have opposed signals here (Figs. 3.25 and 3.21, $b$ and $d$ ), while they have the same signal in the present climate studies. This is consistent to the inter-basin seesaw effect acting throughout TD01 and TD11 toward an increased NADW-like formation, after being perturbed by the IT.

The upper heat content response in the tropical Pacific-like is similar to the modern IT (does not depend on the hemispheric water source), with an ENSO-like signal, but tilted to the north close to the western American-like continent (Fig. $3.25 b$ and $d$ ). By analyzing the reconstructed SSS from paleorecords on the western tropical Pacific, Stott et al. (2002) suggested a change in the hydrographic cycle to explain the increased SSS as an ENSO-like signal, printed on sediments as a bias from more frequent and severe El-Niño events. Their results, however, can be reinterpreted after the present results, as follows: the colder condition in the northern Atlantic reflects the phase whereby the seesaw favors the THC in the Pacific. The concomitant enhanced THC in the Pacific, on the other hand, changes the thermocline transport and increases salinity in northern Pacific by a feedback 
between salinity and the THC (Bryan, 1986b; Saenko et al., 2004). Hence, the colder North Atlantic and the increased SSS on the western tropical Pacific from paleorecords is coherent with the general inter-basin seesaw effect. Moreover, Saenko et al. (2004) have reported a decrease in the IT transport when the THC in the Pacific enhances. Coherently, in the present study, when the IT is open (TD01 and TD11), the THC on the Pacific-like weakens. Hence, when the THC in Pacific enhances, the IT is decreased, and independently of the hemispheric source of the IT waters, it prints the same El-Niño-like anomaly on the tropical Pacific (same anomalies for TD11 and TD01; see Figs. $3.25 b$ and $d$ ). Hence the El-Niño-like signal inferred in paleorecords is in accordance with the effect of a decreased IT, expected during the enhanced THC in the Pacific ocean.

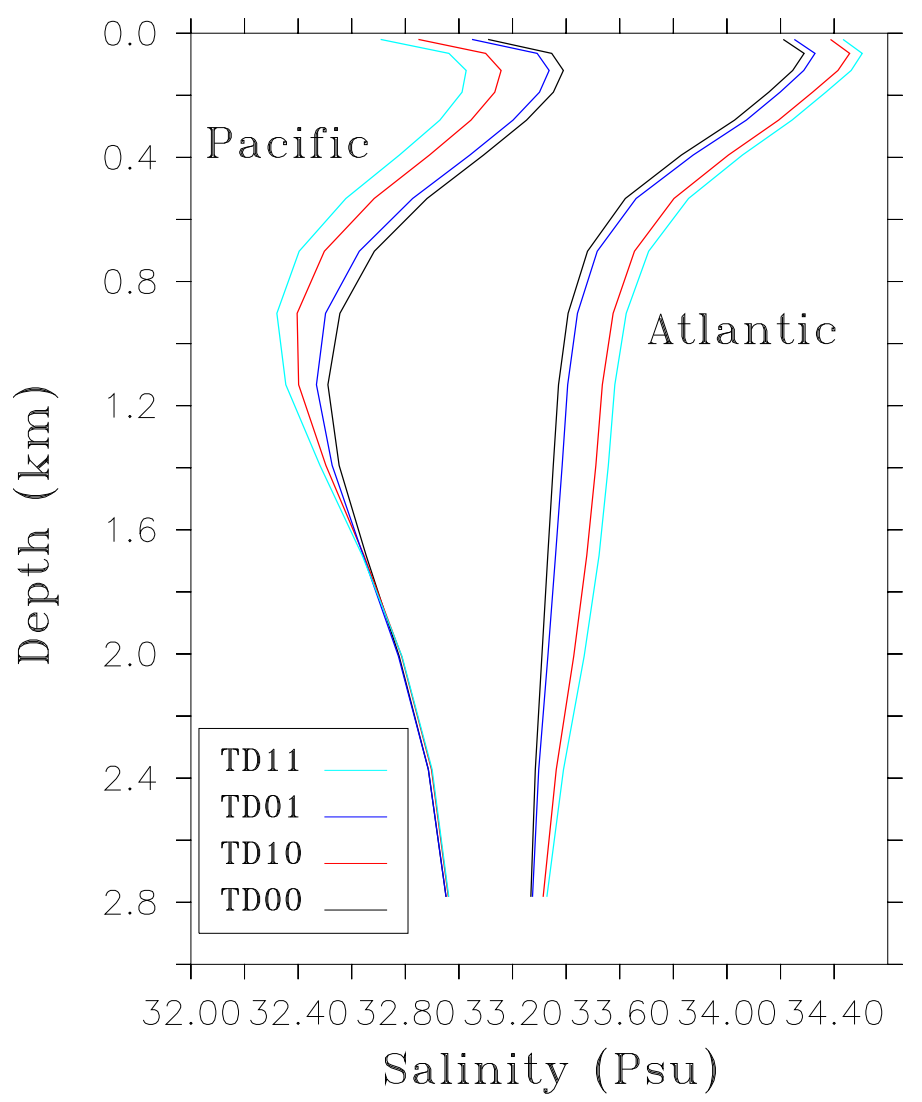

Figure 3.26: The area averaged salinity for northern Atlantic-like and northern Pacific-like basins, for experiments TD00 (black), TD10 (red), TD01 (blue) and TD11 (green). Units in Psu.

Independent of the AL being closed or not, the IT decreases the THC in the Pacific-like while enhancing the AMOC (Figs. 3.23 e to $h$ ). In TD11, the positive salinity anomaly in the Indian-like ocean is advected into the Atlantic-like by the AL. Nevertheless, almost the same salinity departure is found in the northern Atlantic-like in TD01 and TD11 (Fig. 
3.26). In the northern Pacific, however, the salinity stratification changes in a higher rate when the AL is opened (Fig. 3.26), suggesting each basin to have a different sensitivity to the IT, and such difference is due to the freshwater flux in each case.
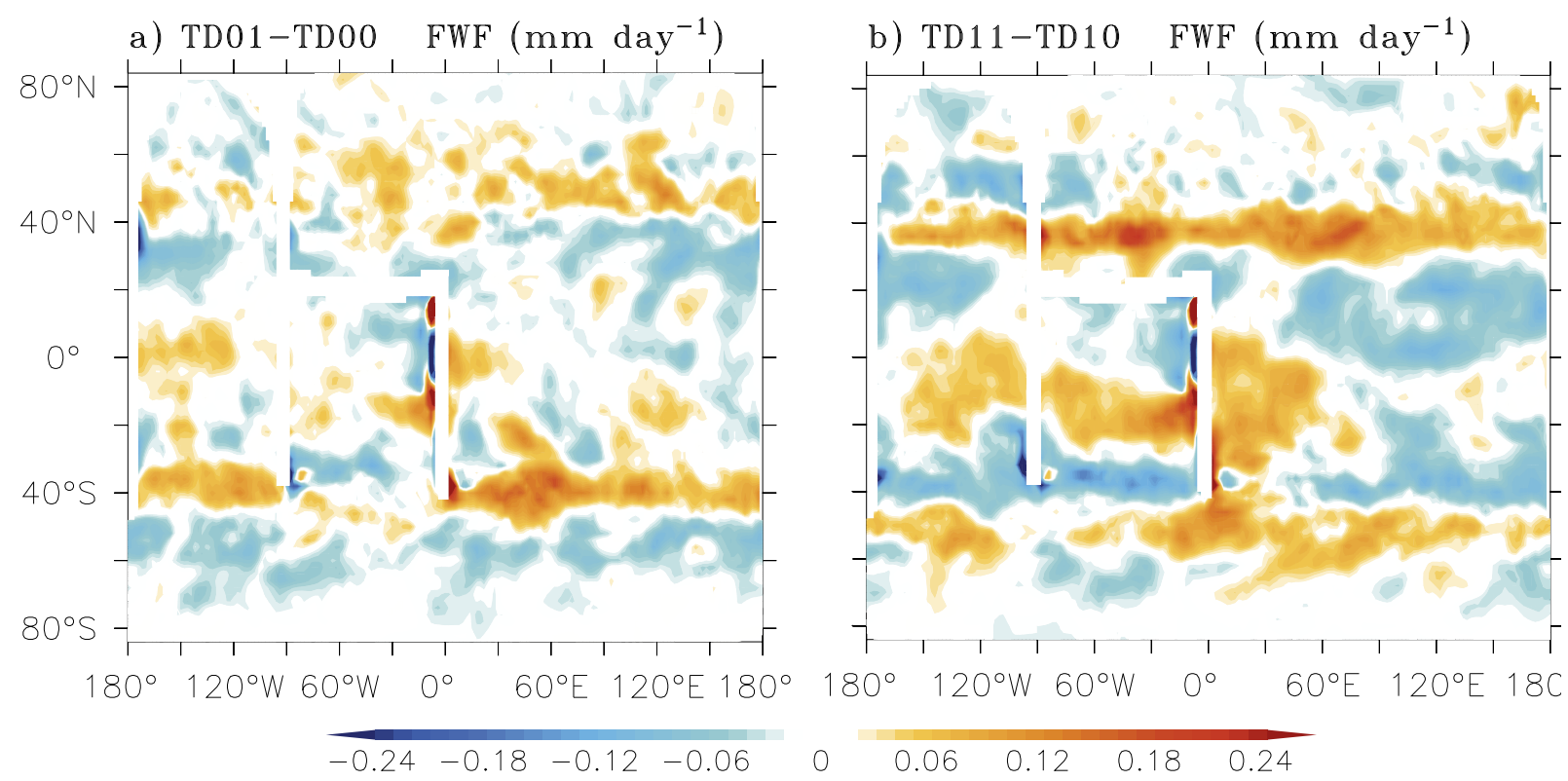

Figure 3.27: The freshwater flux anomalies for TD01 (a) and TD11 (b). Units in $m m \times d a y s^{-1}$.

The freshwater flux contribution to the changes in the northern basin salinity stratification (Fig. 3.26) is considered by averaging the freshwater flux between $20^{\circ} \mathrm{N}$ and $85^{\circ} \mathrm{N}$ in each basin. It is found that the Atlantic-like is forced toward its salinization in both TD01 and TD11, with a slightly greater rate in TD01. However, the departure in the Atlantic-like stratification is slight greater in TD11 (Fig. 3.26), reflecting the positive contribution of the AL to the Atlantic-like salinization in TD11. In the northern Pacific-like, on the other hand, the freshwater forcing is decreased when there is no AL (TD01) and increased when the AL is present (TD11). Despite the negative anomaly of freshwater flux in TD01, the northern Pacific-like SSS is decreased in both cases (Fig. 3.21 $b$ and $d$ ), showing that the changes in oceanic salinity transport due to the IT overcome the freshwater forcing there, increasing the northern Pacific-like stratification. In TD11 the freshwater flux reinforces the IT's impact toward an even fresher northern Pacific-like, which agrees with the greater slow down of the Pacific-like THC in TD11 (Figs. $3.23 f$ and $h$ ). 


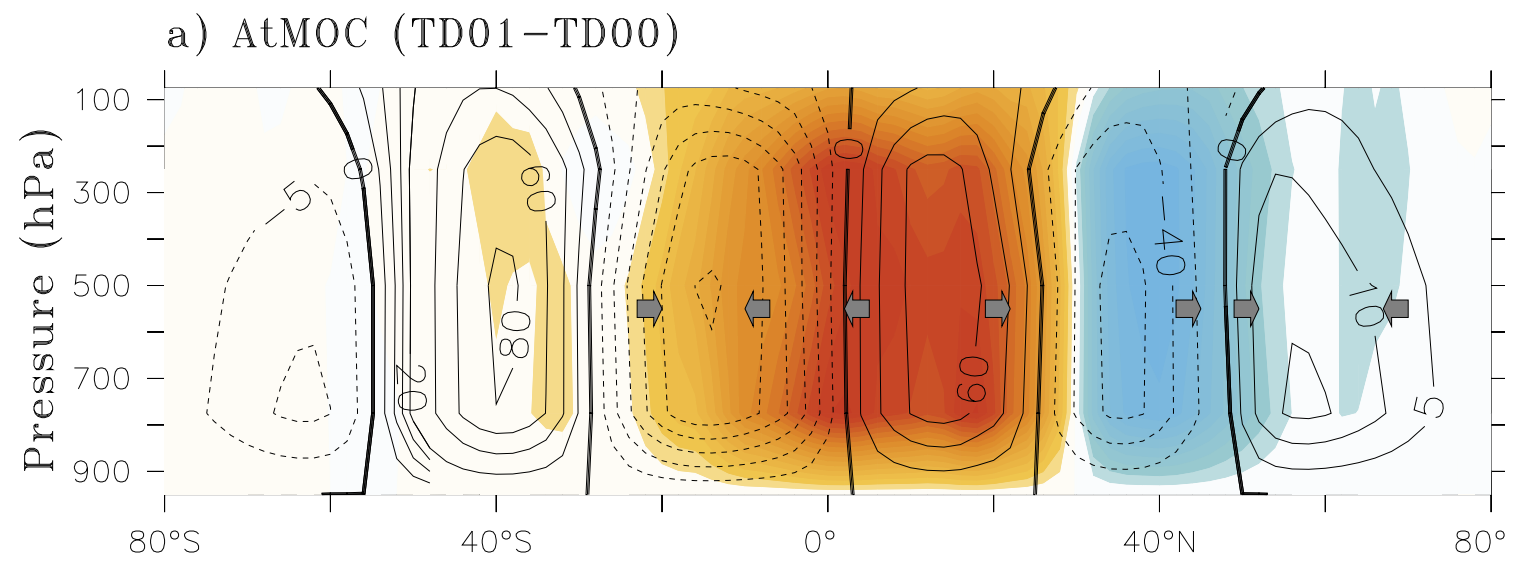

b) $\operatorname{AtMOC}(\mathbb{T D} 1 \mathbb{1}-\mathrm{TD} 10)$

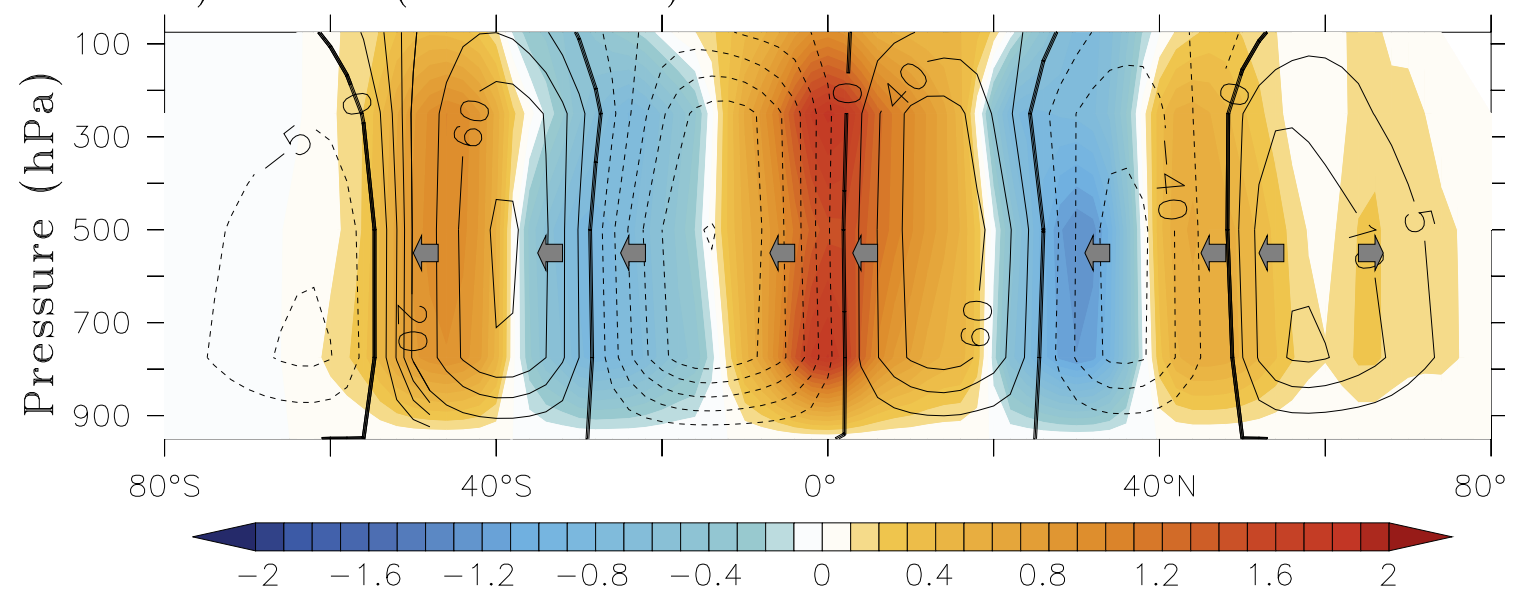

Figure 3.28: The anomalies in the atmospheric MOC stream function for TD01 (a) and TD11 (b). Units in Sv.

Although the inter-basin seesaw response to the IT points to the same direction in both TD11 and TD01 (toward an enhanced NADW formation), there are significant aspects of the IT's impact on these idealized climates that change depending on the AL. This is evident in the anomalies of freshwater flux (Fig. 3.27 $a$ and $b$ ). The anomalies in the tropical region are similar in both TD11 and TD01, with stronger anomalies in TD11. Roughly, the freshwater input in the Atlantic-like enhances, as well as in Indian-like around $20^{\circ}-10^{\circ} \mathrm{S}$ and in the Pacific-like off the equator, except around $120^{\circ} \mathrm{E}$. However, in mid-highlatitudes there are zonal-wide anomalies that shift signals depending on the AL presence. Such pattern of anomalies is observed in DDrake for its zonal Index variability (section 3.2 .3 , indicating that these anomalies may be connected to the atmospheric meridional cells.

This is confirmed in Fig. 3.28 , where the anomalies on the atmospheric MOC is shown. The colored background illustrates the extension of the meridional cell shift, denoted by the 
arrows. The tropical region has similar anomalies in both cases, but in mid-high latitudes the atmospheric MOC has opposite responses to the IT, depending on the AL presence. In TD01, the northern hemisphere Ferrel and Polar cells weaken and shift poleward, while in the TD11 the Polar cell enhances and the Ferrel cell shifts equatorward. In the southern hemisphere mid-high latitudes the changes in the Ferrel cell are similar to its hemispheric counterpart, but with little changes in the Polar cell.

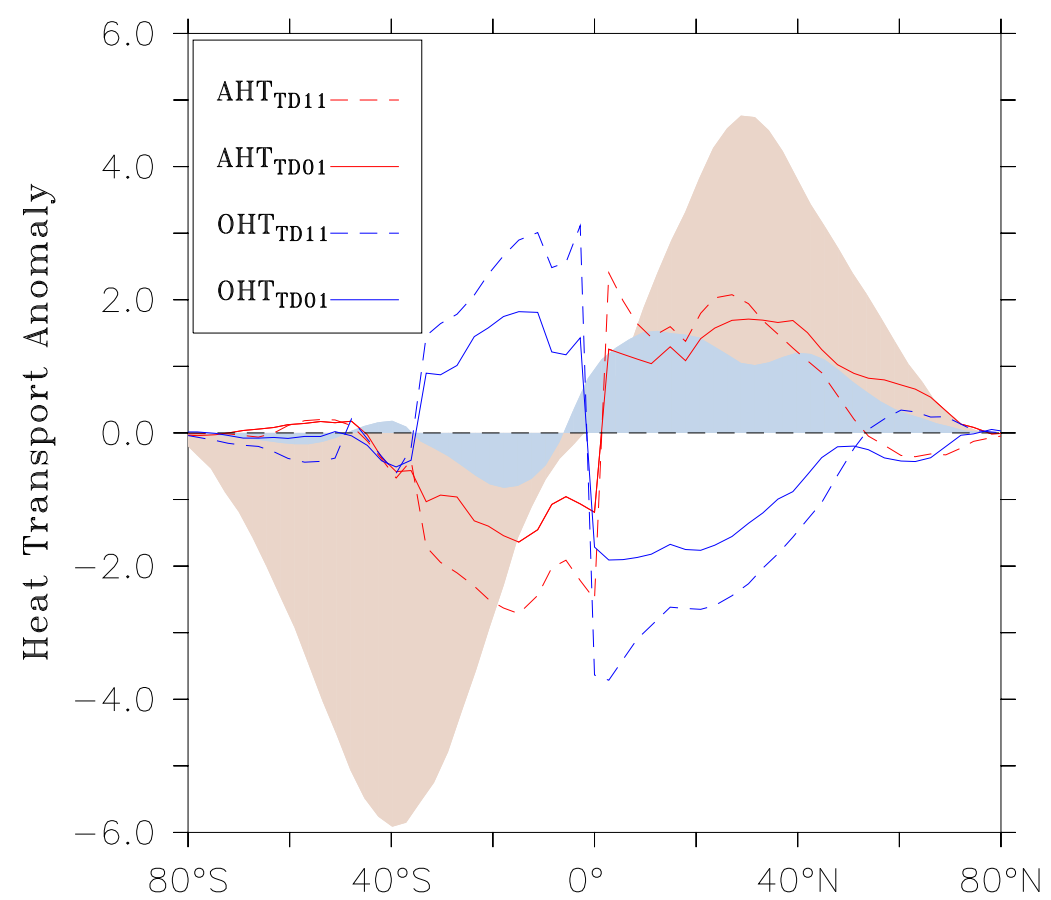

Figure 3.29: Anomalies of OHT (blue) and AHT (red) for TD01 (line) and TD11 (dash). The anomalies are computed regarding the absolute transport, e.g.: $\left|O H T_{T D 11}\right|-\left|O H T_{T D 10}\right|$. Units in $10^{-2} \mathrm{PW}$. The OHT and AHT of TD00 are plotted for reference, in blue and red background, respectively, in PW.

The poleward extent of the Hadley cell is known to be set by the location where the thermally driven jet first becomes baroclinically unstable (Lu et al., 2007). This also controls the latitudinal position of the subtropical dry zone. By analyzing the El-Niño impacts, Seager et al. (2003) described a chain of feedbacks whereby anomalous heating in tropical region intensifies the equatorward flank of the subtropical jet, changing the meridional gradient of potential vorticity and the subtropical critical surface for the equatorward wave propagation. By comparing the impacts of the El-Niño to those from global warming scenarios, Lu et al. (2008) found that, in contrast with the El-Niño response, the Hadley cell weakens and expands poleward as a response to the poleward shift of the eddy activity, which is due to the increased static stability of the subtropical and midlatitude troposphere in a warmed climate. 
Thus, as presented above, the mechanism to shift meridionally the atmospheric cells is grossly based in whether and how (e.g.: changes in static stability or meridional gradient of potential vorticity) the eddy activity is modified meridionally. Moreover, whether the eddy activity changes meridionally, it must impact in the AHT. Coherently, the changes in the AHT are then an indicative of the changes in eddy activity in mid-high latitudes. In addition to these results, the discussion regarding the compensation between OHT and AHT through the Stones's idea (see section 1.3) thus suggest that the mean changes in OHT in mid-high latitudes leads to opposite AHT responses. These changes in AHT, on the other hand, reflects the changes in eddy activity that affects the atmospheric meridional cells extent.

Hence, this suggests that the changes in the THC and in OHT due to the IT may change the eddy activity and the latitudinal position of the atmospheric meridional cells, as observed in Fig. 3.28. To verify this hypothesis, the anomalies in the magnitude of OHT and $\mathrm{AHT}$ (e.g.: $\left|O H T_{T D 11}\right|-\left|O H T_{T D 10}\right|$ ) for TD01 and TD11 are shown in Fig. 3.29, Considering first the northern hemisphere, the OHT increases in TD11 and decreases in TD01 over latitudes between $50^{\circ} \mathrm{N}$ and $90^{\circ} \mathrm{N}$, while between the equator and $50^{\circ} \mathrm{N}$ the OHT decreases in both, but more in TD11. The resulting effects in the AHT are thus different for TD11 and TD01. In TD11, the AHT decreases poleward of $50^{\circ} \mathrm{N}$ and increases equatorward of $50^{\circ} \mathrm{N}$, reaching a maximum increase right on the equatorward flank of the maximum AHT, indicating an equatorward shift in eddy activity. In fact, there is an intensification/weakening in the equatorward/southward flank of the subtropical jet (Fig. $3.30 b$ ) in TD11, indicating an equatorward shift of the baroclinically unstable zone. Returning to Fig. 3.28 , one may confirm the atmospheric meridional cells in the northern hemisphere shift equatorward. 


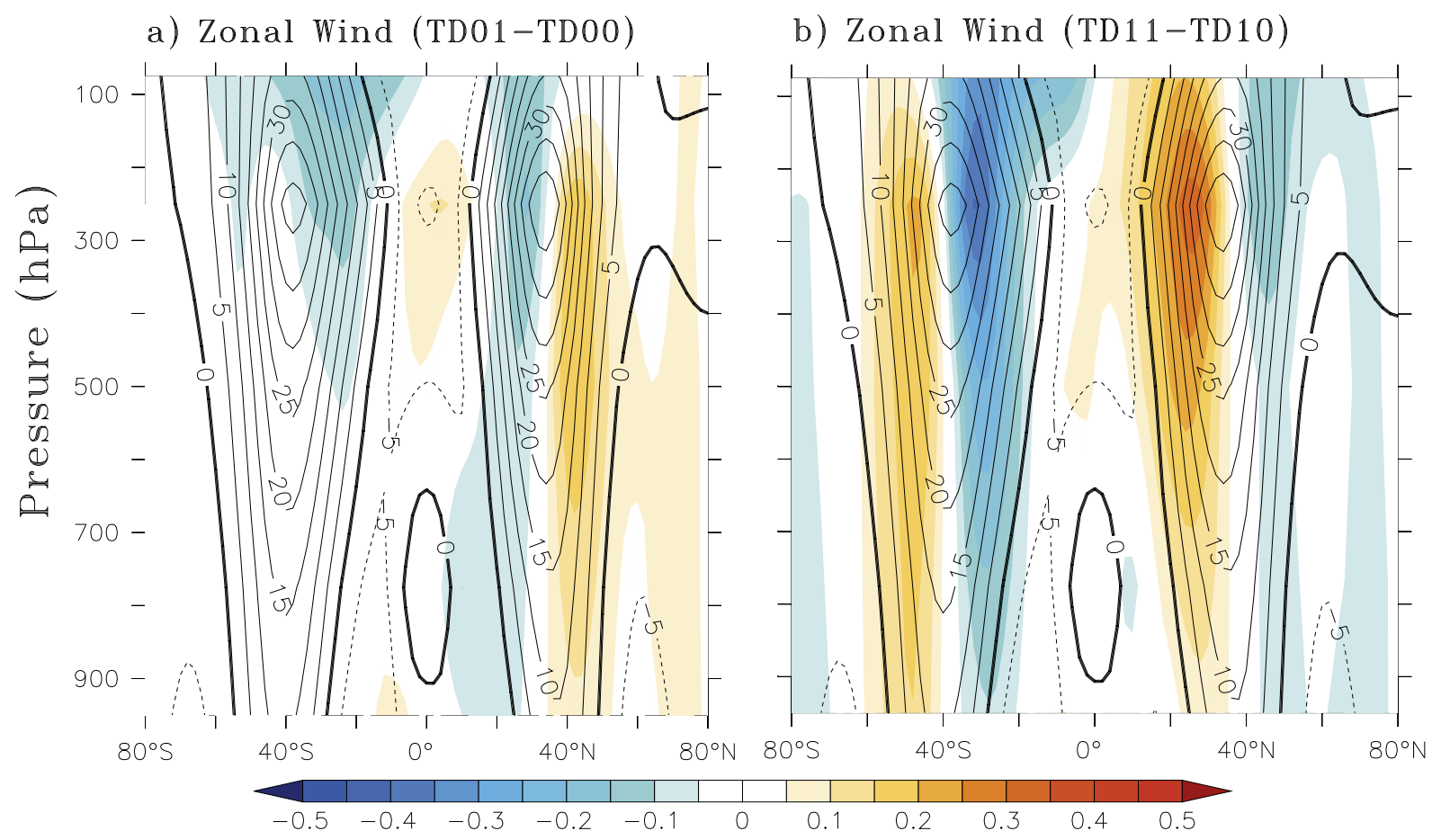

Figure 3.30: Anomalies in the zonal wind for TD01 (a) and TD11 (b). Units in $m s^{-1}$. The contouring shows the zonal wind on TD00 (a) and TD10 (b), for reference.

The AHT in TD01, on the other hand, substantially increases on the poleward flank of the maximum AHT, where the energy transport is eddy-driven, suggesting an enhanced eddy activity in high latitudes. One may recover from section 1.3 that the AHT in tropical regions is mostly due to the mean Hadley cell (Marshall et al., 2014), instead by eddy-driven fluxes, thus the increased AHT in the tropics reflects the strengthening of the Hadley cell observed in both TD01 and TD11 (Fig. 3.28). Consequently, in TD01 the eddy activity is shifted poleward, as observed by the intensification of the poleward flank of the subtropical jet (Fig. $3.30 \mathrm{a}$ ) and coherently to the poleward shift of the atmospheric meridional cells (Fig. $3.28 a)$.

Considering now the southern hemisphere, the OHT is observed to increase the poleward heat transport in both TD01 and TD11, but more efficiently in TD11. Consequently the AHT is proportionally decreased, affecting mostly the northern flank of the maximum AHT in TD11, while there is an weak intensification in AHT poleward of $45^{\circ} \mathrm{S}$. This suggests the eddy-activity shifts poleward, mostly in TD11. The subtropical jet (Fig. $3.30 a$ and $b$ ) is weekend on its equatorward flank, but is strengthened on its poleward flank only in TD11. Coherently, the meridional shift of the atmospheric cells is only noted in TD11 (Fig. $3.28 a$ and $b$ ). 
The differences in the atmospheric response to the IT, dependent on the AL presence, is thus attributed to details in the THC anomalies in these two situation. The Atlanticand Pacific-like basins present their own meridional overturning and both competes to the deepwater formation. The variations in these MOC strength and the temperature departure between their upper and lower branches thus controls the total OHT, which latter impacts in the AHT and the atmospheric meridional cells extent. The high idealization employed here does not permit or intend to exactly quantifiy the arrangement between the OHT from both basins in the past climate, or to ultimately address the meridional position of the atmospheric cells. However, it does show the IT to efficiently change the atmospheric circulation through this mechanism, and that such ability changes with time as the inter-basin seesaw effect shifts its phase and the sensitivity of the THC to the IT. 
Chapter 4

\section{Conclusions}

The MITgcm was employed in a series of experiments to investigate the impacts of increasing the complexity of the ocean topography on the earth's climate. The study starts with an Aquaplanet, where meridional one-grid-wide barriers are gradually added, until an idealized world with an overall climate reminiscent from the observations. At each modification in topography, a criterions analysis of ocean and atmospheric circulation was conducted, until the set up in which an Indonesian Throughflow-like was considered. The main goal was the investigation of the impacts of the Indonesian Throughflow on the Atlantic in an idealized climate expected in glacial periods. This was preceded by the analysis of a series of experiments, where topographical features were gradually added.

\section{The Aquaplanet}

The first step was made with a planet with no lands, covered by a $3 \mathrm{~km}$ deep ocean, the so-called Aquaplanet. As this setup has been well investigated in published studies, the experiments here were run to validate the local MITgcm implementation and also to provide the initial conditions for all other experiments. The Aquaplanet has no barriers for the ocean circulation, which is free to develop as zonal jets with dynamics similar to the Circumpolar Antarctic Current. The meridional overturning in both ocean and atmosphere are symmetric, as expected, modulating the meridional variation of temperature and salinity. The climate obtained in the local Aquaplanet follows the results of Ferreira et al. (2010), as a "warm equilibrium", with no sea-ice formation all over the year. The overall results of the Aquaplanet was in accordance to the results from Marshall et al. (2007), allowing the investigation to move forward with confidence in the local implementation of the numerical model. 


\section{The DDrake}

The second experiment, the DDrake, was also explored on earlier investigations. The two northern basin introduces asymmetries in ocean and atmospheric circulation in both zonal and meridional directions, which gives to its mean state a striking resemblance to observations. The small basin plays the role of the Atlantic, while the large basin is similar to the Indo-Pacific basin. An global thermohaline circulation is developed, mostly concentrate in the Atlantic-like basin, although there still some deep convection in the northern Pacific-like. The global overturning sinks on northern latitudes and returns southward at depths from $800 \mathrm{~m}$ to $1800 \mathrm{~m}$, approximately. The interhemispheric overturning leads to a meridional heat transport that warms the northern hemisphere, with surface temperatures near the northern pole $8^{\circ} \mathrm{C}$ warmer than in the southern pole. Coherently with the stronger overturning in the Atlantic-like, the northern Atlantic-like is saltier than the northern Pacific-like, in response to the freshwater forcing. Although the differences in ocean depth and the total salt content, the zonally averaged salinity in the Atlantic-like basin presents a distribution in the Y-Z plane similar to observed in the real Atlantic, with identifiable structures as such the NADW-like, AABW-like, AAIW-like and SACW-like water masses.

The variability of the DDrake was also investigated. The anomalies in decadal to inter-decadal timescales in the deep ocean circulation were tracked back to its atmospheric forcing, which is an equivalent of the so-called "zonal Index". In DDrake, its effects can be described schematically as a strengthening-expansion vs weakening-contraction of the northern Hadley cell. The meridional shift of the atmospheric cells and wind stress fields lead to heat anomalies due to anomalous Ekman pumping. Those heat anomalies are advected by the mean circulation and feedback to the atmosphere, coloring its spectrum with specific frequencies. This mechanism is described for the Aquaplanet (Marshall et al., 2007), however the Aquaplanet mean circulation differs from the DDrake, where each basin produces a different feedback. In the Pacific-like, the resonance mechanism appears to present two paths on each the heat anomalies recirculate to surface and feedbacks to the atmosphere. In the Atlantic-like, on the other hand, the anomalies are advected by the stronger overturning circulation into the deep ocean. In the same sense that the recirculated heat anomalies in the Pacific-like feedback into the atmosphere, it is reasonable to expected that the heat anomalies introduced into the deep Atlantic-like may impact 
latter into the atmosphere, depending on whether or how they return to surface. These anomalies however were not further investigated.

\section{The Triple Drake}

After a series of attempts and dead-ends experiments, the Triple Drake was developed. It has idealized equivalents for the Atlantic, Indian and Pacific oceans, delimited by the narrow land barriers. The mean climate obtained in this experiment is in accordance to the hypothesized description of an ice-age climate. The thermohaline circulation in the Pacific-like resembles a weaker and shallow version of the Atlantic-like meridional overturning circulation, and competes with the Atlantic-like for the deepwater formation. The meridional heat transport in such equilibrium does not substantially differs from the modern estimative, except for a few details. One may consider the obvious difference between this idealized experiment and all possible glacial climates, which was the absence of sea-ice in all idealized experiments. Although there was no sea-ice in the present experiments, the expected pattern of circulation naturally emerges in the experiments, so the impacts of the AL and IT could be assessed. Additionally, similar approaches were done before (Saenko et al., 2004; Sijp and England, 2009), where idealized experiments were employed and their results interpreted as possible effects during glacial periods, even with no sea-ice formation.

\section{The Agulhas Leakage Effect}

The effects of the Agulhas Leakage on Triple Drake was described, showing the leakage to present the same inter-basin seesaw effect as observed from a poleward shift of the southern hemisphere westerlies Sijp and England (2009). The mass transport of the leakage fills the upper Atlantic-like with saltier thermocline water from the Indian-like basin, decreasing the northern Atlantic-like stratification and providing better conditions for deep convection. The enhanced NADW-like formation impacts latter in the Pacific-like by increasing its salinity through the bottom, weakening its thermohaline circulation.

\section{The Indonesian Throughflow}

The throughflow was designed as a channel that connects the Pacific-like at $10^{\circ} \mathrm{N}$ to the Indian-like at $10^{\circ} \mathrm{S}$. The presence of an inter-hemispheric thermohaline circulation 
in the Pacific-like demands thermocline waters from the southern hemisphere to cross the equator, feeding the meridional cell and the throughflow itself. Such change in the hemispheric water source of the throughflow was within the hypothesized scenario for a glacial period. By comparing simulations where the throughflow was blocked or closed, its overall impacts on climate was assessed. The change in the hemispheric water source to the throughflow changes its impacts as it is known for the modern climate. The salinity anomalies are the most affected, as the relative saltier southern hemisphere replaces the usual low-salinity northern hemisphere waters of the IT. As a consequence of an opened throughflow, the Indian-like and Atlantic-like increases the surface salinity, while in the Pacific-like it is reduced. In modern climate, the blocked throughflow would increase the salinity in the Indian ocean and decreases it in the Pacific, as the low-salinity northern hemisphere waters fills the tropical Pacific. Regarding the heat budget, the impacts of the throughflow is less affected by the change in the hemispheric water source. In the tropical Pacific-like, the response of a blocked (which is extrapolated to a reduced throughflow) has an El-Niño-like signal, but here it tilts southward close to the Pacific-like eastern boundary.

The throughflow was investigated in two situations: with and without the Agulhas Leakage. In both cases, it was found the impacts of the throughflow to be an intensification of the inter-basin seesaw effect toward an enhanced NADW-like formation. Changes in the freshwater forcing in addition to the feedback between the THC and surface salinity leads to the weakening of the THC in the Pacific-like, while the THC and surface salinity was increased in the Atlantic-like. Moreover, the overall impacts of the throughflow were coherent with the past climate inferences. The decrease in the throughflow transport was inferred in paleorecords from the Indonesian Gateways, as also observed in the idealized experiments from an intensified THC in the Pacific. The inverse relationship between the northern Atlantic and the northern Pacific SST from the paleorecords is consistent with the inter-basin seesaw mechanism, which is sensitive to the throughflow. The El-Niño-like signal printed in sediment core in the tropical Pacific, which last for millennia, is also coherent with variation in the throughflow. More than that, the increased THC in the Pacific reduces the throughflow, which has an El-Niño-like signature independent of the hemispheric water source of the throughflow. All these results reinforces the hypothesis of the existence of such inter-basin seesaw mechanism in climate, over which the throughflow presents itself as an mechanism to restore the equilibrium toward the modern climate. It 
is fundamental here to note that, once the THC in the Pacific weakens and the modern climate is reestablished, the hemispheric water source of the throughflow must return to the Northern Pacific. The throughflow transport increases and its impact in the northern Pacific surface salinity becomes positive. In other words, it favors the preconditions to deep convection in the northern Pacific. It is not suggested however the throughflow to shift in the inter-basin seesaw direction, but does suggest it may acts to hold the amplitude of this inter-basin variability.

Although many aspects of the throughflow's impact on climate are insensitive to the AL presence, there are others aspects that respond differently due to the AL. This was found in mid-high latitudes, where the atmospheric meridional cells present opposite responses to the throughflow regarding the AL presence. It was noted that the sensitivity of the THC to the throughflow changes due to the AL. More precisely, the AL shits the inter-basin seesaw toward the Atlantic-like, which changes the background where the throughflow was analyzed. Then, it can be that the THC sensitivity to the throughflow changes depending on the inter-basin seesaw stage. Furthermore, the difference in the THC response to the throughflow directly impacts on the OHT. It was described that these idealized experiments follow reasonably the Stone's constraint, whereby the AHT responds to modifications in OHT. Consequently, the changes in the OHT due to the throughflow lead to AHT responses that also depend on inter-basin seesaw stage. In the atmosphere, in mid-high latitudes, the differences in the AHT reflect changes in the eddy-activity, which is capable of affecting the meridional atmospheric cells in position and strength. Hence, it was found that the differences in the THC response lead to opposite anomalies in the atmosphere. Rather than a causality analysis, it shows the high sensitivity of the atmospheric component of the coupled system. It also alerts that, given the high number of assumptions and idealization employed here, the conclusions should not be too dependent on the atmospheric component. The inter-basin seesaw was reported to be inhibited by imposed freshwater forcing. Hence, the results presented here are best interpreted considering the uncertainties introduced by the freshwater forcing, and configure a possible scenario in which some conditions are satisfied.

The impacts of the throughflow were mostly analyzed under the inter-basin seesaw mechanism effect, which is sensitive to the freshwater forcing. However, the salinization of the Pacific-like in TD01 was achieved under positive freshwater forcing, as also the AL 
appears to dominate the Atlantic-like surface buoyancy over the freshwater forcing. Thus, it is suggested that the overall results presented here, under the inter-basin seesaw point of view, must resist to variations in the freshwater forcing under certain thresholds. 


\section{Bibliography}

ADCROFT A., CAMPIN J.-M., HILL C., MARSHALL J., Implementation of an Atmosphere-Ocean General Circulation Model on the Expanded Spherical Cube, Monthly Weather Review, 2004, vol. 132, p. 2845

ANDERSON R. F., ALI S., BRADTMILLER L. I., NIELSEN S. H. H., FLEISHER M. Q., ANDERSON B. E., BURCKLE L. H., Wind-Driven Upwelling in the Southern Ocean and the Deglacial Rise in Atmospheric CO2, Science, 2009, vol. 323, p. 1443

ANDERSSON H. C., STIGEBRANDT A., Regulation of the Indonesian throughflow by baroclinic draining of the North Australian Basin, Deep Sea Research Part I: Oceanographic Research Papers, 2005, vol. 52, p. 2214

ANTONOV J. I., SEIDOV D., BOYER T. P., LOCARNINI R. A., MiSHONOV A. V., GARCIA H. E., BARANOVA O. K., ZWENG M. M., JOHNSON D. R., World Ocean Atlas 2009, Volume 2: Salinity. vol. Volume 2, Ed. NOAA Atlas NESDIS 69 U.S. Government Printing Office, Washington, D.C., 184 pp., 2010

BARD E., RICKABY R. E. M., Migration of the subtropical front as a modulator of glacial climate, Nature, 2009, vol. 460, p. 380

BEAL L. M., DE RUIJTER W. P. M., BIASTOCH A., ZAHN R., On the role of the Agulhas system in ocean circulation and climate, Nature, 2011, vol. 472, p. 429

BERGER W. H., WEFER G., , 1996 Expeditions into the Past: Paleoceanographic Studies in the South Atlantic. Springer Berlin Heidelberg Berlin, Heidelberg pp 363-410

BIASTOCH A., BOning C. W., LUTJEHARMS J. R. E., Agulhas leakage dynamics 
affects decadal variability in Atlantic overturning circulation, Nature, 2008, vol. 456, p. 489

BISCHOFF T., SCHNEIDER T., The Equatorial Energy Balance, ITCZ Position, and Double-ITCZ Bifurcations, Journal of Climate, 2015, vol. 29, p. 2997

BROCCOLI A. J., DAHL K. A., STOUfFER R. J., Response of the ITCZ to Northern Hemisphere cooling, Geophysical Research Letters, 2006, vol. 33

BRYAN F., High-latitude salinity effects and interhemispheric thermohaline circulations, Nature, 1986a, vol. 323, p. 301

BRYAN F., High-latitude salinity effects and interhemispheric thermohaline circulations, Nature, 1986b, vol. 323, p. 301

CUNNINGHAM S. A., KANZOW T., RAYNER D., BARINGER M. O., JOHNS W. E., MAROTZKE J., LONGWORTH H. R., GRANT E. M., HIRSCHI J. J.-M., BEAL L. M., MEINEN C. S., BRYDEN H. L., Temporal Variability of the Atlantic Meridional Overturning Circulation at $26.5^{\circ} \mathrm{N}$, Science, 2007, vol. 317, p. 935

DANNENMANN S., LINSLEY B. K., OPPO D. W., ROSENTHAL Y., BEAUFORT L., East Asian monsoon forcing of suborbital variability in the Sulu Sea during Marine Isotope Stage 3: Link to Northern Hemisphere climate, Geochemistry, Geophysics, Geosystems, 2003, vol. 4, p. 1

DE DECKKER P., TAPPER N. J., VAN DER KAARS S., The status of the Indo-Pacific Warm Pool and adjacent land at the Last Glacial Maximum, Global and Planetary Change, 2003, vol. 35, p. 25

DE RUIJTER W. P., AKEN H. M., BEIER E. J., LUTJEHARMS J. R., MATANO R. P., SCHOUTEN M. W., Eddies and dipoles around South Madagascar: formation, pathways and large-scale impact, Deep Sea Research Part I: Oceanographic Research Papers, 2004, vol. 51, p. 383

DELWORTH T. L., MANN M. E., Observed and simulated multidecadal variability in the Northern Hemisphere, Climate Dynamics, 2000, vol. 16, p. 661 
DIJKSTRA H. A., DE RUIJTER W. P. M., On the Physics of the Agulhas Current: Steady Retroflection Regimes, Journal of Physical Oceanography, 2001, vol. 31, p. 2971

DU Y., QU T., Three inflow pathways of the Indonesian throughflow as seen from the simple ocean data assimilation, Dynamics of Atmospheres and Oceans, 2010, vol. 50, p. 233

DUPLESSY J. C., SHACKLETON N. J., FAIRBANKS R. G., LABEYRIE L., OPPO D., KALLEL N., Deepwater source variations during the last climatic cycle and their impact on the global deepwater circulation, Paleoceanography, 1988, vol. 3, p. 343

ENDERTON D., MARSHALL J., Explorations of Atmosphere-Ocean-Ice Climates on an Aquaplanet and Their Meridional Energy Transports, Journal of the Atmospheric Sciences, 2009, vol. 66, p. 1593

ENGLAND M. H., HUANG F., On the Interannual Variability of the Indonesian Throughflow and Its Linkage with ENSO, Journal of Climate, 2005, vol. 18, p. 1435

FANG G., SUSANTO R. D., WIRASANTOSA S., QIAO F., SUPANGAT A., FAN B., WEI Z., SULISTIYO B., LI S., Volume, heat, and freshwater transports from the South China Sea to Indonesian seas in the boreal winter of 2007-2008, Journal of Geophysical Research: Oceans, 2010, vol. 115

FERREIRA D., MARSHALL J., CAMPIN J.-M., Localization of Deep Water Formation: Role of Atmospheric Moisture Transport and Geometrical Constraints on Ocean Circulation, Journal of Climate, 2010, vol. 23, p. 1456

FERREIRA D., MARSHALL J., ROSE B., Climate Determinism Revisited: Multiple Equilibria in a Complex Climate Model, Journal of Climate, 2010, vol. 24, p. 992

FIEUX M., ANDRIÉ C., DELECLUSE P., IlAHUDE A. G., KARTAVTSEFF A., MANTISI F., MOLCARD R., SWALLOW J. C., Measurements within the Pacific-Indian oceans throughflow region, Deep Sea Research Part I: Oceanographic Research Papers, 1994, vol. 41, p. 1091

FOlland C. K., COLMAN A. W., ROWELl D. P., K. M., Predictability of Northeast Brazil Rainfall and Real-Time Forecast Skill, 1987-98, Journal of Climate, 2001, vol. 14, p. 1937 
FOLLAND C. K., PALMER T. N., PARKER D. E., Sahel rainfall and worldwide sea temperatures, 1901-85, Nature, 1986, vol. 320, p. 602

GANACHAUD A., WUNSCH C., Improved estimates of global ocean circulation, heat transport and mixing from hydrographic data, Nature, 2000, vol. 408, p. 453

GENT P. R., MCWILLIAMS J. C., Isopycnal Mixing in Ocean Circulation Models, Journal of Physical Oceanography, 1990, vol. 20, p. 150

GINGELE F. X., DE DECKKER P., HILLENBRAND C.-D., Clay mineral distribution in surface sediments between Indonesia and NW Australia - source and transport by ocean currents, Marine Geology, 2001a, vol. 179, p. 135

GINGELE F. X., DE DECKKER P., HILLENBRAND C.-D., Late Quaternary fluctuations of the Leeuwin Current and palaeoclimates on the adjacent land masses: clay mineral evidence, Australian Journal of Earth Sciences, 2001b, vol. 48, p. 867

Godfrey J. S., A sverdrup model of the depth-integrated flow for the world ocean allowing for island circulations, Geophysical and Astrophysical Fluid Dynamics, 1989, vol. 45, p. 89

GODFREY J. S., The effect of the Indonesian throughflow on ocean circulation and heat exchange with the atmosphere: A review, Journal of Geophysical Research: Oceans, 1996, vol. 101, p. 12217

GODFREY J. S., WILKIN J., HIRST A. C., Why Does the Indonesian Throughflow Appear to Originate from the North Pacific?, Journal of Physical Oceanography, 1993, vol. 23 , p. 1087

GOLDENBERG S. B., LANDSEA C. W., MESTAS-NUÑEZ A. M., GRAY W. M., The Recent Increase in Atlantic Hurricane Activity: Causes and Implications, Science, 2001, vol. 293 , p. 474

GORDON A. L., Interocean exchange of thermocline water, Journal of Geophysical Research: Oceans, 1986, vol. 91, p. 5037

GORDON A. L., SUSANTO R. D., FFIELD A., Throughflow within Makassar Strait, Geophysical Research Letters, 1999, vol. 26, p. 3325 
GORDON A. L., SUSANTO R. D., VRANES K., Cool Indonesian throughflow as a consequence of restricted surface layer flow, Nature, 2003, vol. 425, p. 824

GORDON A. L., WEISS R. F., SMETHIE W. M., WARNER M. J., Thermocline and intermediate water communication between the south Atlantic and Indian oceans, Journal of Geophysical Research: Oceans, 1992, vol. 97, p. 7223

HAARSMA R. J., CAMPOS E. J. D., DRIJFHOUT S., HAZELEGER W., SEVERIJNS C., Impacts of interruption of the Agulhas leakage on the tropical Atlantic in coupled ocean-atmosphere simulations, Climate Dynamics, 2011, vol. 36, p. 989

HANEBUth T., STATTEGGER K., GROOTES P. M., Rapid Flooding of the Sunda Shelf: A Late-Glacial Sea-Level Record, Science, 2000, vol. 288, p. 1033

HAUTAla S. L., SPRINTALL J., POTEMRA J. T., CHONG J. C., PANDOE W., BRAY N., ILAHUDE A. G., Velocity structure and transport of the Indonesian Throughflow in the major straits restricting flow into the Indian Ocean, Journal of Geophysical Research: Oceans, 2001, vol. 106, p. 19527

HIRST A. C., GODFREY J. S., The Role of Indonesian Throughflow in a Global Ocean GCM, Journal of Physical Oceanography, 1993, vol. 23, p. 1057

HIRST A. C., GODFREY J. S., The Response to a Sudden Change in Indonesian Throughflow in a Global Ocean GCM, Journal of Physical Oceanography, 1994, vol. 24, p. 1895

HOLBOURN A., KUHNT W., XU J., Indonesian Throughflow variability during the last 140 ka: the Timor Sea outflow, Geological Society, London, Special Publications, 2011, vol. 355 , p. 283

HUGHES G. O., HOGG A. M. C., GRIfFithS R. W., Available Potential Energy and Irreversible Mixing in the Meridional Overturning Circulation, Journal of Physical Oceanography, 2009, vol. 39, p. 3130

KALNAY E., KANAMitSu M., KISTLER R., COLLINS W., DEAVEN D., GANDIN L., IREDELl M., SAHA S., WHITE G., WOOLlEN J., ZHU Y., LEETMAA A., REYNOLDS R., CHELLIAH M., EBISUZAKI W., HIGGINS W., JANOWIAK J., MO 
K. C., ROPELEWSKI C., WANG J., JENNE R., JOSEPH D., The NCEP/NCAR 40Year Reanalysis Project, Bulletin of the American Meteorological Society, 1996, vol. 77, p. 437

KANG S. M., HELD I. M., FRIERSON D. M. W., ZHAO M., The Response of the ITCZ to Extratropical Thermal Forcing: Idealized Slab-Ocean Experiments with a GCM, Journal of Climate, 2008, vol. 21, p. 3521

KEIGWIN L. D., Glacial-age hydrography of the far northwest Pacific Ocean, Paleoceanography, 1998, vol. 13, p. 323

KIEFER T., SARNTHEIN M., ERLENKEUSER H., GROOTES P. M., ROBERTS A. P., North Pacific response to millennial-scale changes in ocean circulation over the last 60 kyr, Paleoceanography, 2001, vol. 16, p. 179

Knight J., Allan R., Folland C., Vellinga M., Mann M., A Signature of Persistent Natural Thermohaline Circulation Cycles in Observed Climate, AGU Fall Meeting Abstracts, 2005

KNORR G., LOHMANN G., Southern Ocean origin for the resumption of Atlantic thermohaline circulation during deglaciation, Nature, 2003, vol. 424, p. 532

LAMBECK K., YOKOYAMA Y., PURCELL A., JOHNSTON P., Reply to the comment by W.R. Peltier, Quaternary Science Reviews, 2002, vol. 21, p. 415

LE BARS D., DE RUiJTER W. P. M., DiJKSTRA H. A., A New Regime of the Agulhas Current Retroflection: Turbulent Choking of Indian-Atlantic leakage, Journal of Physical Oceanography, 2012, vol. 42, p. 1158

LE BARS D., DIJKSTRA H. A., DE RUIJTER W. P. M., Impact of the Indonesian Throughflow on Agulhas leakage, Ocean Science, 2013, vol. 9, p. 773

LEA D. W., PAK D. K., SPERO H. J., Climate Impact of Late Quaternary Equatorial Pacific Sea Surface Temperature Variations, Science, 2000, vol. 289, p. 1719

LISIECKI L. E., RAYMO M. E., CURRY W. B., Atlantic overturning responses to Late Pleistocene climate forcings, Nature, 2008, vol. 456, p. 85 
LOCARnini R. A., V. M. A., I. A. J., P. B. T., E. G. H., K. B. O., M. Z. M., R. J. D., World Ocean Atlas 2009, Volume 1: Temperature. vol. Volume 1, Ed. NOAA Atlas NESDIS 68 U.S. Government Printing Office, Washington, D.C., 184 pp, 2010

LU J., CHEN G., FRIERSON D. M. W., Response of the Zonal Mean Atmospheric Circulation to El Niño versus Global Warming, Journal of Climate, 2008, vol. 21, p. 5835

LU J., VECCHI G. A., REICHLER T., Expansion of the Hadley cell under global warming, Geophysical Research Letters, 2007, vol. 34

MAHAJAN S., ZHANG R., DELWORTH T. L., Impact of the Atlantic Meridional Overturning Circulation (AMOC) on Arctic Surface Air Temperature and Sea Ice Variability, Journal of Climate, 2011, vol. 24, p. 6573

MARShall J., ADCROFT A., CAMPIN J.-M., HILL C., WHITE A., AtmosphereOcean Modeling Exploiting Fluid Isomorphisms, Monthly Weather Review, 2004, vol. 132 , p. 2882

MARShall J., ADCROFT A., HILl C., PERElMAN L., HEISEY C., A finite-volume, incompressible Navier Stokes model for studies of the ocean on parallel computers, Journal of Geophysical Research, 1997, vol. 102, p. 5753

MARSHALL J., DONOHOE A., FERREIRA D., MCGEE D., The ocean's role in setting the mean position of the Inter-Tropical Convergence Zone, Climate Dynamics, 2014, vol. 42 , p. 1967

MARSHALL J., FERREIRA D., CAMPIN J.-M., ENDERTON D., Mean Climate and Variability of the Atmosphere and Ocean on an Aquaplanet, Journal of the Atmospheric Sciences, 2007, vol. 64, p. 4270

MEYERS G., Variation of Indonesian throughflow and the El Niño-Southern Oscillation, Journal of Geophysical Research: Oceans, 1996, vol. 101, p. 12255

MEYERS G., BAILEY R. J., WORBY A. P., Geostrophic transport of Indonesian throughflow, Deep Sea Research Part I: Oceanographic Research Papers, 1995, vol. 42, p. 1163 
MILLER J. R., RUSSELL G. L., Ocean heat transport during the Last Glacial Maximum, Paleoceanography, 1989, vol. 4, p. 141

MOLCARD R., FIEUX M., SYAMSUDIN F., The throughflow within Ombai Strait, Deep Sea Research Part I: Oceanographic Research Papers, 2001, vol. 48, p. 1237

MOLTENI F., Atmospheric simulations using a GCM with simplified physical parametrizations. I: Model climatology and variability in multi-decadal experiments, Climate Dynamics, 2003, vol. 20, p. 175

MÜLLER A., OPDYKE B. N., Glacial-interglacial changes in nutrient utilization and paleoproductivity in the Indonesian Throughflow sensitive Timor Trough, easternmost Indian Ocean, Paleoceanography, 2000, vol. 15, p. 85

MUNK W., WUNSCH C., Abyssal recipes II: energetics of tidal and wind mixing, Deep Sea Research Part I: Oceanographic Research Papers, 1998, vol. 45, p. 1977

MURRAY S. P., ARIEF D., Throughflow into the Indian Ocean through the Lombok Strait, January 1985-January 1986, Nature, 1988, vol. 333, p. 444

NILSSON J., LANGEN P. L., FERREIRA D., MARSHALL J., Ocean Basin Geometry and the Salinification of the Atlantic Ocean, Journal of Climate, 2013, vol. 26, p. 6163

OLIVER J. E., , 2005 Zonal Index. Springer Netherlands Dordrecht pp 820-822

OPPO D. W., LINSLEY B. K., ROSENTHAL Y., DANNENMANN S., BEAUFORT L., Orbital and suborbital climate variability in the Sulu Sea, western tropical Pacific, Geochemistry, Geophysics, Geosystems, 2003, vol. 4, p. 1

PAPARELLA F., YOUNG W. R., Horizontal convection is non-turbulent, Journal of Fluid Mechanics, 2002, vol. 466, p. 205

PAUL A., SCHÄFER-NETH C., Modeling the water masses of the Atlantic Ocean at the Last Glacial Maximum, Paleoceanography, 2003, vol. 18

PEETERS F. J. C., ACHESON R., BRUMMER G.-J. A., DE RUIJTER W. P. M., SCHNEIDER R. R., GANSSEN G. M., UFKES E., KROON D., Vigorous exchange between the Indian and Atlantic oceans at the end of the past five glacial periods, Nature, 2004, vol. 430 , p. 661 
PELTIER W. R., Comments on the paper of Yokoyama et al. (2000), entitled "Timing of the Last Glacial Maximum from observed sea level minima", Quaternary Science Reviews, 2002, vol. 21, p. 409

POTEMRA J. T., SCHNEIDER N., Interannual variations of the Indonesian throughflow, Journal of Geophysical Research: Oceans, 2007, vol. 112

PRESS W. H., FLANNERY B., TEUKOLSKY S., VETTERLING W., Numerical recipes: the art of scientific computing, 818 pp. Cambridge Univ. Press, New York, 1986

RAU A., ROGERS J., CHEN M.-T., Late Quaternary palaeoceanographic record in giant piston cores off South Africa, possibly including evidence of neotectonism, Quaternary International, 2006, vol. 148, p. 65

REDI M. H., Oceanic Isopycnal Mixing by Coordinate Rotation, Journal of Physical Oceanography, 1982, vol. 12, p. 1154

ROBINSON W. A., The dynamics of the zonal index in a simple model of the atmosphere, Tellus A: Dynamic Meteorology and Oceanography, 1991, vol. 43, p. 295

ROSENTHAL Y., OPPO D. W., LINSLEY B. K., The amplitude and phasing of climate change during the last deglaciation in the Sulu Sea, western equatorial Pacific, Geophysical Research Letters, 2003, vol. 30

SAEnKO O. A., SCHMitTneR A., WEAVER A. J., The Atlantic-Pacific Seesaw, Journal of Climate, 2004, vol. 17, p. 2033

SANDSTROM J. W., Dynamische versuche mit meerwasser, Ann. d. Hydr. u. Marit. Meterol., 1908, vol. 36, p. 6

SCHMITTNER A., LATIF M., SCHNEIDER B., Model projections of the North Atlantic thermohaline circulation for the 21st century assessed by observations, Geophysical Research Letters, 2005, vol. 32

SCHMITZ W. J., Observations of New, Large and Stable Abyssal Currents at Midlatitudes along $165^{\circ}$ E, Journal of Physical Oceanography, 1987, vol. 17, p. 1309

SCHNEIDER N., The Indonesian Throughflow and the Global Climate System, Journal of Climate, 1998, vol. 11, p. 676 
SCHNEIDER N., BARNETT T. P., Indonesian throughflow in a coupled general circulation model, Journal of Geophysical Research: Oceans, 1997, vol. 102, p. 12341

SCHONTEN M. W., DE RUIJTER W. P. M., VAN LEEUWEN P. J., LUTJEHARMS J. R. E., Translation, decay and splitting of Agulhas rings in the southeastern Atlantic Ocean, Journal of Geophysical Research: Oceans, 2000, vol. 105, p. 21913

SCHOUTEN M. W., DE RUIJTER W. P. M., VAN LEEUWEN P. J., Upstream control of Agulhas Ring shedding, Journal of Geophysical Research: Oceans, 2002, vol. 107, p. 23

SEAGER R., HARNIK N., KUSHNIR Y., ROBINSON W., MILLER J., Mechanisms of Hemispherically Symmetric Climate Variability, Journal of Climate, 2003, vol. 16, p. 2960

SIJP W. P., ENGLAND M. H., Southern Hemisphere Westerly Wind Control over the Ocean's Thermohaline Circulation, Journal of Climate, 2009, vol. 22, p. 1277

SONG Q., VECCHI G. A., ROSATI A. J., The Role of the Indonesian Throughflow in the Indo-Pacific Climate Variability in the GFDL Coupled Climate Model, Journal of Climate, 2007, vol. 20, p. 2434

SPEICH S., BLANKE B., CAI W., Atlantic meridional overturning circulation and the Southern Hemisphere supergyre, Geophysical Research Letters, 2007, vol. 34

SPRINTALL J., WIJFFELS S., GORDON A. L., FFIELD A., MOLCARD R., SUSANTO R. D., SOESILO I., SOPAHELUWAKAN J., SURACHMAN Y., VAN AKEN H. M., INSTANT: A new international array to measure the Indonesian Throughflow, Eos, Transactions American Geophysical Union, 2004, vol. 85, p. 369

SPRINTALL J., WIJFFELS S. E., MOLCARD R., JAYA I., Direct estimates of the Indonesian Throughflow entering the Indian Ocean: 2004-2006, Journal of Geophysical Research: Oceans, 2009, vol. 114

STONE P. H., Constraints on dynamical transports of energy on a spherical planet, Dynamics of Atmospheres and Oceans, 1978, vol. 2, p. 123 
STOTT L., POUlSEN C., LUND S., THUNELl R., Super ENSO and Global Climate Oscillations at Millennial Time Scales, Science, 2002, vol. 297, p. 222

SUSANTO R. D., GORDON A. L., Velocity and transport of the Makassar Strait throughflow, Journal of Geophysical Research: Oceans, 2005, vol. 110

SUSANTO R. D., WEI Z., ADI R. T., FAN B., LI S., FANG G., Observations of the Karimata Strait througflow from December 2007 to November 2008, Acta Oceanologica Sinica, 2013, vol. 32, p. 1

SUTTON R. T., HODSON D. L. R., Atlantic Ocean Forcing of North American and European Summer Climate, Science, 2005, vol. 309, p. 115

TORREnCE C., COMPO G. P., A Practical Guide to Wavelet Analysis, Bulletin of the American Meteorological Society, 1998, vol. 79, p. 61

TRENBERTH K. E., CARON J. M., Estimates of Meridional Atmosphere and Ocean Heat Transports, Journal of Climate, 2001, vol. 14, p. 3433

VALSALA V., MAKSYUTOV S., MURTUGUDDE R., Interannual to Interdecadal Variabilities of the Indonesian Throughflow Source Water Pathways in the Pacific Ocean, Journal of Physical Oceanography, 2011, vol. 41, p. 1921

VAN SEBILLE E., SPRINTALL J., SCHWARZKOPF F. U., SEN GUPTA A., SANTOSO A., ENGLAND M. H., BIASTOCH A., BÖNING C. W., Pacific-to-Indian Ocean connectivity: Tasman leakage, Indonesian Throughflow, and the role of ENSO, Journal of Geophysical Research: Oceans, 2014, vol. 119, p. 1365

VAN SEBILLE E., VAN LEEUWEN P. J., Fast Northward Energy Transfer in the Atlantic due to Agulhas Rings, Journal of Physical Oceanography, 2007, vol. 37, p. 2305

VELLINGA M., WU P., Low-Latitude Freshwater Influence on Centennial Variability of the Atlantic Thermohaline Circulation, Journal of Climate, 2004, vol. 17, p. 4498

VISSER K., THUNELL R., STOTT L., Magnitude and timing of temperature change in the Indo-Pacific warm pool during deglaciation, Nature, 2003, vol. 421, p. 152 
WAJSOWICZ R. C., The Circulation of the Depth-integrated Flow around an Island with Application to the Indonesian Throughflow, Journal of Physical Oceanography, 1993a, vol. 23 , p. 1470

WAJSOWICZ R. C., A Simple Model of the Indonesian Throughflow and Its Composition, Journal of Physical Oceanography, 1993b, vol. 23, p. 2683

WAJSOWICZ R. C., A Relationship between Interannual Variations in the South Pacific Wind Stress Curl, the Indonesian Throughflow, and the West Pacific Warm Water Pool, Journal of Physical Oceanography, 1994, vol. 24, p. 2180

WAJSOWICZ R. C., GORDON A. L., FFIELD A., SUSANTO R. D., Estimating transport in Makassar Strait, Deep Sea Research Part II: Topical Studies in Oceanography, 2003, vol. 50, p. 2163

WAJSOWICZ R. C., SCHNEIDER E. K., The Indonesian Throughflow's Effect on Global Climate Determined from the COLA Coupled Climate System, Journal of Climate, 2001, vol. 14 , p. 3029

WATTERSON I. G., Southern Midlatitude Zonal Wind Vacillation and Its Interaction with the Ocean in GCM Simulations, Journal of Climate, 2000, vol. 13, p. 562

WEBB R. S., RIND D. H., LEHMAN S. J., HEALY R. J., SIGMAN D., Influence of ocean heat transport on the climate of the Last Glacial Maximum, Nature, 1997, vol. 385, p. 695

WEIJER W., DE RUIJTER W. P. M., DIJKSTRA H. A., Stability of the Atlantic Overturning Circulation: Competition between Bering Strait Freshwater Flux and Agulhas Heat and Salt Sources, Journal of Physical Oceanography, 2001, vol. 31, p. 2385

WEIJER W., RUIJTER W. P. D., STERL A., DRIJFHOUT S. S., Response of the Atlantic overturning circulation to South Atlantic sources of buoyancy, Global and Planetary Change, 2002, vol. 34, p. 293

WINTON M., A Reformulated Three-Layer Sea Ice Model, Journal of Atmospheric and Oceanic Technology, 2000, vol. 17, p. 525

WUNSCH C., What Is the Thermohaline Circulation?, Science, 2002, vol. 298, p. 1179 
WYRTKI K., , 1961 Physical Oceanography of the Southeast Asian waters

WYRTKI K., Indonesian through flow and the associated pressure gradient, Journal of Geophysical Research: Oceans, 1987, vol. 92, p. 12941

XU J., Change of Indonesian Throughflow outflow in response to East Asian monsoon and ENSO activities since the Last Glacial, Science China Earth Sciences, 2014, vol. 57, p. 791

YOKOYAMA Y., LAMBECK K., DE DECKKER P., JOHNSTON P., FIFIELD L. K., Timing of the Last Glacial Maximum from observed sea-level minima, Nature, 2000, vol. 406 , p. 713

YOSHIMORI M., BROCCOLI A. J., Equilibrium Response of an Atmosphere-Mixed Layer Ocean Model to Different Radiative Forcing Agents: Global and Zonal Mean Response, Journal of Climate, 2008, vol. 21, p. 4399

YUAN D., WANG J., XU T., XU P., HUI Z., ZHAO X., LUAN Y., ZHENG W., YU Y., Forcing of the Indian Ocean Dipole on the Interannual Variations of the Tropical Pacific Ocean: Roles of the Indonesian Throughflow, Journal of Climate, 2011, vol. 24, p. 3593

ZHANG R., Anticorrelated multidecadal variations between surface and subsurface tropical North Atlantic, Geophysical Research Letters, 2007, vol. 34

ZHANG R., Coherent surface-subsurface fingerprint of the Atlantic meridional overturning circulation, Geophysical Research Letters, 2008, vol. 35

ZHANG R., DELWORTH T. L., Simulated Tropical Response to a Substantial Weakening of the Atlantic Thermohaline Circulation, Journal of Climate, 2005, vol. 18, p. 1853 